\title{
Estudo histomorfométrico do efeito da injeção de dexametasona na fase tardia de cicatrização de prega vocal de coelho
}

\author{
Tese apresentada à Faculdade de Medicina da \\ Universidade de São Paulo para obtenção do \\ título de Doutor em Ciências \\ Programa de Otorrinolaringologia \\ Orientador: Dr. Rui Imamura
}

São Paulo

2014 
Dados Internacionais de Catalogação na Publicação (CIP)

Preparada pela Biblioteca da

Faculdade de Medicina da Universidade de São Paulo

Creprodução autorizada pelo autor

Takahashi-Ramos, Marystella Tomoe

Estudo histomorfométrico do efeito da injeção de dexametasona na fase tardia de cicatrização de prega vocal de coelho / . -- São Paulo, 2014.

Tese(doutorado)--Faculdade de Medicina da Universidade de São Paulo. Programa de Otorrinolaringologia.

Orientador: Rui Imamura.

Descritores: 1.Pregas vocais 2.Cicatrização/efeitos de drogas 3.Cicatriz 4.Esteroides 5.Dexametasona 6.Injeções intralesionais 6.Coelhos

USP/FM/DBD-110/14 


\section{DEDICATÓRIA}

Aos meus pais, Deise e Antonio, cujo amor, dedicação e apoio incondicionais foram essenciais em minha formação e na concretização de meus sonhos.

Ao meu marido Henrique, pela paciência, compreensão e, sobretudo, pelo amor que ilumina o meu caminho e me inspira a ser uma pessoa melhor a cada dia.

Ao meu irmão Tetsuya, pela amizade, amor, cumplicidade $e$ presença em todos momentos importantes de minha vida. 


\section{AGRADECIMENTOS}

Ao Dr. Rui Imamura, médico assistente doutor do Hospital das Clínicas da FMUSP, dotado de imenso saber, pela valiosa orientação desta tese e pela disponibilidade e generosidade em compartilhar seus conhecimentos. Sem sua contribuição este trabalho não seria possível.

Ao Prof. Dr. Domingos Hiroshi Tsuji, Professor Associado da Disciplina de Otorrinolaringologia da FMUSP, meu mestre na Laringologia, a quem sou eternamente grata pela amizade, ensinamentos, confiança e oportunidades proporcionadas. Seus ensinamentos e conselhos foram imprescindíveis ao meu desenvolvimento profissional.

Ao Prof. Dr. Luiz Ubirajara Sennes, Professor Associado e Coordenador do Programa de Pós-graduação da Disciplina de Otorrinolaringologia da FMUSP, pela amizade e exemplo de justiça e ética que sempre se fizeram presentes. Seus ensinamentos muito contribuíram para o meu crescimento.

Ao Prof. Dr. Ricardo Ferreira Bento, Professor Titular da Disciplina de Otorrinolaringologia da FMUSP, pelo empreendedorismo no gerenciamento da Clínica que possibilita a formação acadêmica de seus alunos neste centro de excelência.

Aos Prof. Dr. Ivan Dieb Miziara, Dr. Ronaldo Frizzarini e Dr. Fabio de Rezende Pinna, pelas críticas e sugestões pertinentes durante o meu exame de qualificação.

À Dra. Adriana Hachiya, médica assistente doutora do Hospital das Clínicas da FMUSP, pela amizade, conselhos, incentivos constantes e oportunidades proporcionadas.

Aos médicos assistentes doutores do grupo de Laringologia do Hospital das Clínicas da FMUSP, Dr. Henry Ugadin Koishi, Dr. Luiz Prata Figueiredo e Dra. Patrícia Paula Santoro, pelos ensinamentos. 
Aos amigos Alexandre Akio Nakasato, Ali Mahmoud, Allex Itar Ogawa, Bárbara Elvina Ulisses Parente Queiroz, Camila Cristina Ishikawa, Sílvia Bona Nascimento e Tatiana Alves Monteiro pela convivência prazerosa e boas recordações da época de residência.

Aos meus sogros, Sergio Ramos e Rosangela Faria Ramos, por todo o carinho e atenção com que me receberam em sua família.

À Andrea Hiromi Nomi, pela amizade, disponibilidade em sempre me ajudar e pelo Theo que está prestes a chegar.

Ao Dr. Edwin Roger Parra Cuentas, médico do Departamento de Patologia da FMUSP, pelo auxílio nas análises histológicas deste estudo.

Ao Dr. Eduardo Pompeu, médico veterinário do Biotério Central da FMUSP, pela cessão de animais e por permitir o uso das instalações para a realização deste estudo.

Ao Claudionor Donizete Vidotti, funcionário do Biotério Central da FMUSP, cuja ajuda foi essencial para a realização dos procedimentos experimentais.

Às secretárias Maria Marileide Alves, Maria Márcia Alves e Lucivânia Lima da Silva, por toda atenção e ajuda dispensada durante o período de residência e pós-graduação.

À Melissa Bastos, funcionária do Laboratório de Investigação Médica (LIM32), por sua ajuda e prestabilidade durante a pesquisa.

À Coordenação de Aperfeiçoamento de Pessoal de Nível Superior (CAPES), pela contribuição financeira por meio da bolsa de estudos. 
Esta tese está de acordo com as seguintes normas, em vigor no momento desta publicação:

Referências: adaptado de International Committee of Medical Journals Editors (Vancouver).

Universidade de São Paulo. Faculdade de Medicina. Divisão de Biblioteca e Documentação. Guia de apresentação de dissertações, teses e monografias. Elaborado por Anneliese Carneiro da Cunha, Maria Julia de A. L. Freddi, Maria F. Crestana, Marinalva de Souza Aragão, Suely Campos Cardoso, Valéria Vilhena. 3a ed. São Paulo: Divisão de Biblioteca e Documentação; 2011.

Abreviaturas dos títulos dos periódicos de acordo com List of Journals Indexed in Index Medicus. 


\section{SUMÁRIO}

Lista de Siglas

Lista de Abreviaturas

Lista de Símbolos

Lista de Quadros

Lista de Figuras

Lista de Tabelas

Resumo

Abstract

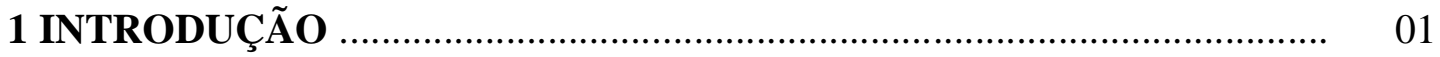

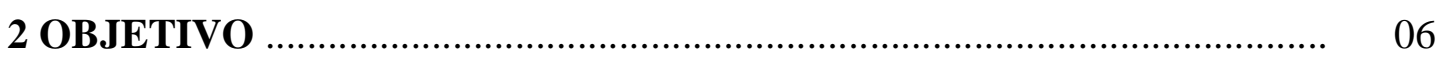

3 REVISÃO DA LITERATURA …....................................................... 08

3.1 Histologia da prega vocal ......................................................................... 09

3.2 Cicatrização .................................................................................. 11

3.2.1 Hemostasia e inflamação - início imediatamente após a lesão até o $4^{\circ}-6^{\circ}$ dia

3.2.2 Proliferação - $4^{\mathrm{o}}$ ao $14^{\mathrm{o}}$ dia após a lesão .................................................... 14

3.2.3 Maturação e remodelagem - $8^{\circ}$ dia ao $1^{\circ}$ ano após a lesão .......................... 15

3.3 Cicatrização da prega vocal ...................................................................... 16

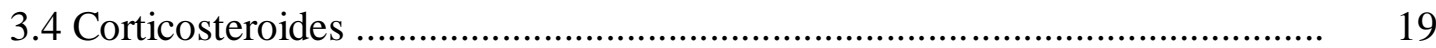

3.4.1 Mecanismo de ação ................................................................................ 21

3.4.2 Uso intralesional de corticosteroides em afecções laríngeas ..................... 26

$3.5 \mathrm{O}$ coelho como modelo animal para experimentação em laringologia .......... 30

3.6 Uso do método de Picrossírius-polarização para histomorfometria do

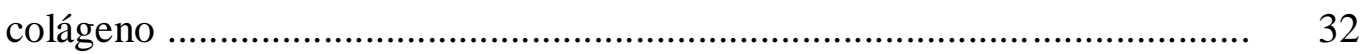

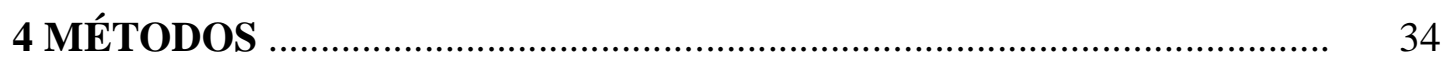

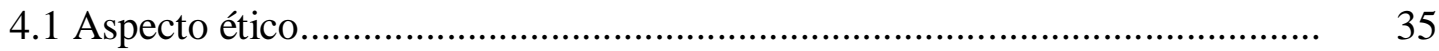

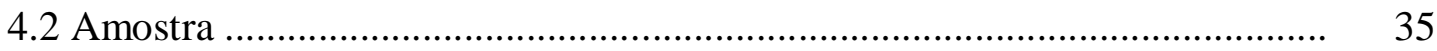

4.3 Procedimento pré-operatório ................................................................... 36 


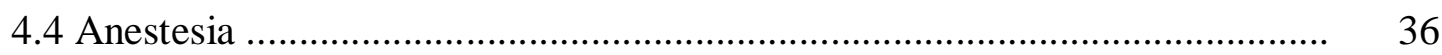

4.5 Procedimento cirúrgico ...................................................................... 37

4.6 Procedimento pós-operatório ..................................................................... 41

4.7 Eutanásia dos animais e isolamento das laringes ........................................... 41

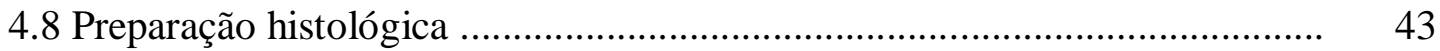

4.9 Análise morfométrica .................................................................................... 43

4.9.1 Quantificação do infiltrado inflamatório, edema e hemorragia ................. 43

4.9.2 Análise do Sistema de Fibras de Colágeno ............................................... 46

4.10 Análise estatística ............................................................................ 50

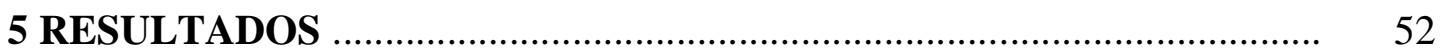

5.1 Evolução dos coelhos durante o período observacional ................................ 53

5.2 Variáveis de interesse .......................................................................... 53

5.2.1 Processo inflamatório na lâmina própria .................................................... 53

5.2.2 Distribuição das fibras de colágeno e densidade de colágeno na lâmina própria

6 DISCUSSÃO

6.1 Delineamento do estudo e metodologia ..................................................... 65

6.2 Efeito da dexametasona sobre a lâmina própria ........................................... 68

6.2.1 Processo inflamatório ............................................................................. 68

6.2.2 Fibras de colágeno ............................................................................. 71

6.3 Perspectivas futuras .............................................................................. $\quad 74$

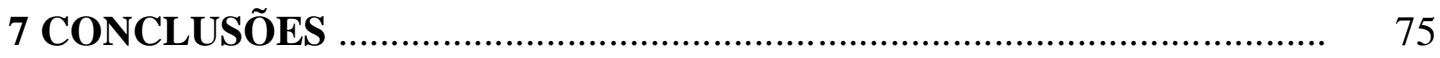

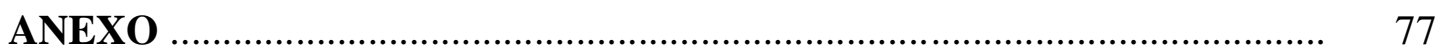

Anexo A - Média da área proporcional de colágeno ........................................ 78

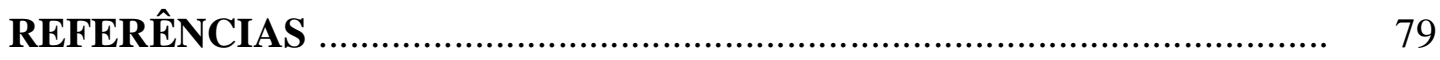

APÊNDICE

Apêndice - Carta de aprovação da Comissão de Ética em Pesquisa da FMUSP 


\section{LISTA DE SIGLAS}

CAPES Coordenação de Aperfeiçoamento de Pessoal de Nível Superior

DTAEP Diretoria Técnica de Apoio ao Ensino e Pesquisa

FMUSP Faculdade de Medicina da Universidade de São Paulo

USP Universidade de São Paulo 


\section{LISTA DE ABREVIATURAS}

\begin{tabular}{|c|c|}
\hline $\mathrm{CBG}$ & globulina de ligação dos corticosteroides \\
\hline $\mathrm{COX}$ & ciclooxigenase \\
\hline COX-2 & ciclooxigenase 2 \\
\hline DNA & ácido desoxirribonucleico \\
\hline EGF & fator de crescimento epidermal \\
\hline ELAM-1 & molécula de adesão leucocitária endotelial \\
\hline GM-CSF & fator de estimulação de colônias de granulócitos-macrófagos \\
\hline GR & receptor de glicocorticoide \\
\hline GRBAS & escala para avaliação perceptivo-auditiva da voz \\
\hline GRE & elementos responsivos aos glicocorticoides \\
\hline $\mathrm{HE}$ & hematoxilina-eosina \\
\hline HSP & proteína do choque térmico \\
\hline ICAM & molécula de adesão intracelular \\
\hline $\operatorname{Ig}$ & imunoglobulina \\
\hline IL-1 & interleucina 1 \\
\hline IL-2 & interleucina 2 \\
\hline IL-3 & interleucina 3 \\
\hline IL-6 & interleucina 6 \\
\hline IL-1 $\beta$ & interleucina $1 \beta$ \\
\hline IFN & interferon \\
\hline $\mathrm{KCl}$ & cloreto de potássio \\
\hline NOS-2 & óxido nítrico sintase \\
\hline $\mathrm{p}$ & nível descritivo \\
\hline $\mathrm{P}_{25 \%}$ & percentil $25 \%$ \\
\hline $\mathrm{P}_{75 \%}$ & percentil $75 \%$ \\
\hline PAF & fator ativador de plaqueta \\
\hline PDGF & fator de crescimento derivado de plaqueta \\
\hline PF-4 & fator plaquetário 4 \\
\hline
\end{tabular}




$\begin{array}{ll}\text { PL } & \text { fosfolipase } \\ \text { PL-A } & \text { fosfolipase } \mathrm{A}_{2} \\ \text { PS } & \text { Picrossírius } \\ \text { PV D } & \text { prega vocal direita } \\ \text { PV E } & \text { prega vocal esquerda } \\ \text { RNAm } & \text { ácido ribonucleico mensageiro } \\ \text { TGF- } \beta & \text { fator de transformação de crescimento beta } \\ \text { TNF- } \alpha & \text { fator de necrose tumoral alfa } \\ \text { UI } & \text { unidade internacional } \\ \text { VEGF } & \text { fator de crescimento vascular endotelial } \\ \text { VHI } & \text { índice de desvantagem vocal }\end{array}$




\section{LISTA DE SÍMBOLOS}

$\begin{array}{ll}\mathrm{C} & \text { Celsius } \\ \mathrm{cm} & \text { centímetro } \\ \mathrm{GHz} & \text { gigahertz } \\ \mathrm{kg} & \text { quilograma } \\ \mathrm{mg} & \text { miligrama } \\ \mathrm{mL} & \text { mililitro } \\ \mu \mathrm{m} & \text { micrometro } \\ \mathrm{x} & \text { vezes } \\ / & \text { dividido por } \\ 0 & \text { grau } \\ \text { o } & \text { indicador ordinal masculino } \\ \text { a } & \text { indicador ordinal feminino } \\ = & \text { igual a } \\ { }_{\circledast} & \text { marca registrada } \\ \% & \text { porcento }\end{array}$




\section{LISTA DE QUADROS}

Quadro 1 Elementos da resposta inflamatória e suas funções ................ 13

$\begin{array}{lll}\text { Quadro } 2 & \text { Potências relativas e doses equivalentes de corticosteroides .. } & 21\end{array}$

Quadro 3 Efeitos dos glicocorticoides sobre os componentes da resposta inflamatória e imune 


\section{LISTA DE FIGURAS}

Figura 1 Efeitos dos glicocorticoides na resposta inflamatória (A) e imune (B). Os glicocorticoides inibem a conversão da fosfatidilcolina em ácido araquidônico por meio da indução de síntese de lipocortina, que inibe a ação da fosfolipase $\mathrm{A}_{2}$ $\left(\mathrm{PL}-\mathrm{A}_{2}\right)$. Assim, ocorre também inibição de produção e ação de leucotrienos. Mediante a inibição da ciclooxigenase (COX), ocorre também inibição da síntese de prostaglandinas e tromboxanos. Por meio do bloqueio de síntese da interleucina $1 \beta$ (IL-1 $\beta$ ), há redução no número de linfócitos T circulantes e redução de produção de anticorpos

Figura 2 Posicionamento do animal na mesa cirúrgica .......................

Figura 3 Desenho esquemático ilustra o laringoscópio e suas dimensões

Figura 4 Imagens do laringoscópio: (A) visão lateral; (B) visão anterior

Figura 5 Imagem da pinça bisturi. Em detalhe, medida do reparo ........ $\quad 40$

Figura 6 Imagem da incisão em prega vocal esquerda ........................ 40

Figura 7 Imagem da agulha de injeção. Em detalhe, medida do reparo 41

Figura 8 Cervicotomia com identificação da laringe ........................... 42

Figura 9 Interface do programa de análise digital de imagem que mostra a fotomicrografia com corte histológico de prega vocal, corado em $\mathrm{HE}$, e aplicação de retículo para quantificação de células inflamatórias. Aumento de 400x .....

Figura 10 Fotomicrografia de corte histológico de prega vocal corado em HE. Aumento de 400x

Figura 11 Fotomicrografia de corte histológico corado com Picrossírius e visualizado sob luz convencional não polarizada (A) e polarizada (B). Aumento de 400x 
Figura 12 Interface do programa de análise digital de imagem que mostra a fotomicrografia com delimitação da área de interesse para quantificação de fibras de colágeno marcada em verde. Aumento de 400x

Figura 13 Interface do programa de análise digital de imagem que mostra a fotomicrografia com delimitação da área de interesse e reconhecimento das frequências de luz birrefringentes correspondentes às fibras colágenas, marcando-as em vermelho, expressa em $\mu \mathrm{m}^{2}$. Aumento de 400x

Figura 14 Interface do programa de análise digital de imagem que mostra a fotomicrografia com marcação da área total, expressa em $\mu \mathrm{m}^{2}$. Aumento de 400x

Figura 15 Corte histológico corado com hematoxilina-eosina de prega vocal esquerda (controle) (A) e direita (intervenção) (B) do Grupo I (sacrifício no $7^{\circ}$ dia de pós-operatório). Aumento de $400 \mathrm{x}$

Figura 16 Corte histológico corado com hematoxilina-eosina de prega vocal esquerda (controle) (A) e direita (intervenção) (B) do Grupo II (sacrifício no $180^{\circ}$ dia de pós-operatório). Aumento de $400 x$

Figura 17 Corte histológico de prega vocal direita (intervenção) do Grupo I (sacrifício no $7^{\circ}$ dia de pós-operatório) corado com Picrossírius e visualizado sob luz polarizada. Aumento de 400x

Figura 18 Corte histológico de prega vocal esquerda (controle) do Grupo I (sacrifício no $7^{\circ}$ dia de pós-operatório) corado com Picrossírius e visualizado sob luz polarizada. Aumento de $400 \mathrm{x}$ 
Figura 19 Corte histológico de prega vocal esquerda (controle) do Grupo II (sacrifício no $180^{\circ}$ dia de pós-operatório) corado com Picrossírius e visualizado sob luz polarizada. Aumento de 400x

Figura 20 Corte histológico de prega vocal direita (intervenção) do Grupo II (sacrifício no $180^{\circ}$ dia de pós-operatório) corado com Picrossírius e visualizado sob luz polarizada. Aumento de 400x 


\section{LISTA DE TABELAS}

Tabela 1 Comparação das variáveis inflamatórias entre prega vocal direita e esquerda do Grupo I (sacrifício no $7^{\circ}$ dia de pósoperatório)

Tabela 2 Comparação das variáveis inflamatórias entre prega vocal direita e esquerda do Grupo II (sacrifício no $180^{\circ}$ dia de pósoperatório)

Tabela 3 Comparação das variáveis inflamatórias da prega vocal esquerda (controle) entre Grupo I (sacrifício no $7^{\circ}$ dia de pós-operatório) e Grupo II (sacrifício no $180^{\circ}$ dia de pósoperatório)

Tabela 4 Comparação das variáveis inflamatórias da prega vocal direita (intervenção) entre Grupo I (sacrifício no $7^{\circ}$ dia de pós-operatório) e Grupo II (sacrifício no $180^{\circ}$ dia de pósoperatório)

Tabela 5 Média da densidade de colágeno das pregas vocais esquerda e direita nos Grupo I (sacrifício no $7^{\circ}$ dia de pós-operatório) e II (sacrifício no $180^{\circ}$ dia de pós-operatório) 


\section{RESUMO}

Ramos MTT. Estudo histomorfométrico do efeito da injeção de dexametasona na fase tardia de cicatrização de prega vocal de coelho. [tese]. São Paulo: Faculdade de Medicina, Universidade de São Paulo; 2014.

INTRODUÇÃO: Apesar dos avanços recentes nas técnicas e instrumentos de fonomicrocirurgia, cicatriz de prega vocal é a principal causa de persistência ou recorrência de disfonia após a microcirurgia de laringe. A cicatriz de prega vocal continua sendo um dos maiores desafios da laringologia, uma vez que ainda não existe um tratamento consistentemente eficaz para restaurar a função vocal adequadamente. Muitos cirurgiões fazem uso empírico de injeções de corticosteroides na prega vocal durante a fonomicrocirurgia, na tentativa de evitar ou reduzir a formação de cicatriz, apesar da inexistência de evidências científicas que justifiquem seu uso. Em estudo prévio realizado na Disciplina de Otorrinolaringologia da Faculdade de Medicina da Universidade de São Paulo, a injeção intracordal de corticosteroide intraoperatória levou à redução significativa de deposição de colágeno, sem diferença no número de células inflamatórias, no terceiro e sétimo dia de pós-operatório. Desconhece-se, no entanto, se essas alterações persistem em fases mais tardias da cicatrização da prega vocal. O objetivo deste estudo foi, portanto, investigar a existência de benefícios em longo prazo da injeção intralesional de corticosteroide no processo cicatricial da prega vocal. MÉTODO: catorze coelhos albinos machos da raça New Zealand foram submetidos a incisão em toda extensão das pregas vocais seguida de injeção de dexametasona na prega vocal direita. A prega vocal esquerda não recebeu injeção e serviu como controle. As laringes foram excisadas em dois períodos: sete e 180 dias de pós-operatório. A coloração de hematoxilina-eosina foi utilizada para a análise quantitativa da resposta inflamatória e o método de Picrossírius-polarização para análise quantitativa e descritiva de deposição de colágeno. RESULTADOS: Houve um aumento não significativo na quantidade de células inflamatórias na prega vocal tratada com corticosteroide no grupo sacrificado no $7^{\circ}$ dia de pós-operatório. Não foram observadas diferenças significativas na resposta inflamatória entre as pregas vocais do grupo sacrificado no $180^{\circ}$ dia de pós-operatório ou quando os grupos sacrificados no $7^{\circ}$ e $180^{\circ}$ dia foram comparados. Foi observada tendência à redução na deposição de colágeno na prega vocal tratada no $7^{\circ}$ dia de pós-operatório, o que não ocorreu na avaliação do $180^{\circ}$ dia. Não foram observadas diferenças significativas quando os grupos foram comparados entre si (grupo sacrificado no $7^{\circ}$ dia versus grupo sacrificado no $180^{\circ}$ dia). As pregas vocais que receberam injeção de dexametasona apresentaram melhor organização e menor espessura das fibras de colágeno do que as pregas vocais controle, tanto na avalição do $7^{\circ}$ quanto $180^{\circ}$ dia de pós-operatório. CONCLUSÃO: Os resultados deste estudo sugerem que, embora a injeção intracordal de corticosteroide não tenha tido impacto significativo sobre a quantidade de células inflamatórias ou taxa de deposição de colágeno, ela propiciou uma melhor 
organização e menor espessura das fibras de colágeno na fase crônica da cicatrização.

Descritores: Pregas vocais; Cicatrização/efeitos de drogas; Cicatriz; Esteroides; Dexametasona; Injeções intralesionais; Coelhos. 


\begin{abstract}
Takahashi-Ramos MT. Histomorphometric study of chronic wound healing in rabbit vocal fold after steroid injection [thesis]. São Paulo: "Faculdade de Medicina, Universidade de São Paulo"; 2014.

INTRODUCTION: Despite recent advances in phonosurgery techniques and instruments, vocal fold scar is the greatest cause of poor voice outcome following laryngeal surgery. Vocal fold scarring remains one of the most challenging problems in the clinical practice of laryngology, since a consistently effective treatment to restore adequate vocal function has not been established yet. Many surgeons empirically use corticosteroid submucosal injection during phonosurgery in an attempt to prevent scar formation despite the lack of evidence to support its use. In a previous study conducted in the Discipline of Otorhinolaryngology of University of Sao Paulo School of Medicine, intracordal corticosteroid injection immediately after injury led to significantly reduced collagen deposition with no change in number of inflammatory cells at the third e seventh day post-lesion in a rabbit model. It is not known, however, if these findings persist on later phases of wound healing. Thus, the purpose of this study was to investigate the existence of long-term benefits from the use of intracordal corticosteroid injection in the wound healing process of the vocal folds. METHODS: Fourteen male albino New Zealand rabbits underwent bilateral vocal fold incision followed by dexamethasone injection into the right vocal fold. The left vocal fold was not injected and served as control. Larynges were harvested at two time points: seven (group 1) and 180 days (group 2). Hematoxylin-eosin staining was used for quantitative analysis of inflammatory response and Picrosirius polarization method for quantitative and descriptive analysis of collagen deposition. RESULTS: There was a non-significant increase in inflammatory cells in the steroidtreated vocal fold on day 7 . No significant differences in the inflammatory response were observed between vocal folds on day 180 or when group 1 was compared with group 2. There was a trend for reduction in collagen deposition in the treated vocal folds on day 7 , but no significant difference on day 180 . No significant difference was observed when group 1 (day 7) was compared with group 2 (day 180). Collagen fibers were better organized and thinner in the steroid-treated vocal fold in both time points of sacrifice. CONCLUSION: The present results suggest that, although corticosteroid intracordal injection has no significant impact on the number of inflammatory cells or collagen rate deposition, it leads to a better and more organized arrangement of collagen fibers on chronic phase of wound healing.
\end{abstract}

Descriptors: Vocal cords; Wound healing/drug effects; Cicatrix; Steroids; Dexamethasone; Injections, intralesional; Rabbits. 
1 INTRODUÇÃO 


\section{INTRODUÇÃO}

A voz influencia praticamente todos os aspectos da interação e cultura humanas. Até um passado não tão longínquo era o único meio de comunicação disponível, por meio do qual era feito o registro dos eventos e a história do homem era transmitida. Apesar do grande aumento de registros da informação na forma escrita, impressa e digitalizada ocorrido nos últimos tempos, a maioria das pessoas ainda usa a voz como meio primário de comunicação (Benninger, Murry, 2006).

Não é de se estranhar, portanto, que alterações na qualidade vocal podem afetar a qualidade de vida das pessoas (Garrett et al., 2010). Como a voz também constitui parte importante da identidade do indivíduo, um problema de voz pode resultar em autoimagem distorcida que, juntamente com o problema vocal, pode ser debilitante tanto social como economicamente (Ramig, Verdolini, 1998; Isshiki et al., 1999). Estudos mostram que pacientes com disfonia sofrem de isolamento social, depressão e redução de qualidade de vida geral e específica, comparável ao de pacientes com insuficiência cardíaca, angina, ciatalgia e doença pulmonar obstrutiva crônica (Benninger et al., 1998; Mirza et al., 2003; Rosen et al., 2004; Roy et al., 2005; Cohen et al., 2006). Além do impacto na saúde e qualidade de vida, problemas vocais geram um custo social elevado, com gastos em visitas médicas e queda na produtividade por absenteísmo no trabalho (Ramig, Verdolini, 1998). Estima-se que cerca de um terço da população apresenta algum tipo de alteração de voz em algum momento da vida (Roy et al.,2004; Roy et al., 2005). 
As disfonias podem ser decorrentes de vários distúrbios, sejam eles funcionais ou orgânicos. Os de origem funcional geralmente podem ser tratados clinicamente por meio de fonoterapia, enquanto os de origem orgânica, por tratamento clínico ou cirúrgico (Isshiki et al.,1999). Segundo Coyle et al. (2001), cerca de $22 \%$ dos pacientes que procuram atendimento para problemas vocais apresentam lesão orgânica em pregas vocais.

As técnicas atuais de fonomicrocirurgia para exérese de lesões benignas são baseadas nos conhecimentos obtidos a partir da descrição da estrutura da prega vocal (Hirano, 1975) e teoria de corpo-cobertura de vibração da prega vocal (Hirano, Kakita, 1985) e objetivam aperfeiçoar o resultado por meio da exérese da lesão com mínima ruptura dos componentes normais da prega vocal (Garrett, Ossoff, 2000). Contudo, por mais que as técnicas tenham evoluído, complicações podem ocorrer, a maioria relacionada à formação de cicatriz, com prejuízo da vibração da prega vocal. Segundo Woo et al. (1994), a cicatriz de prega vocal é a principal causa de persistência ou recorrência de disfonia após microcirurgia de laringe.

Em 1994, o Comitê de Distúrbios da Fala, Voz e Deglutição da Academia Americana de Otorrinolaringologia e Cirurgia de Cabeça e Pescoço definiu cicatriz de prega vocal como a substituição do tecido normal por tecido fibroso como consequência de uma lesão ou doença. Independentemente da etiologia, a cicatriz pode alterar a ultraestrutura da lâmina própria da prega vocal, interferindo na interface corpo-cobertura e propagação da onda mucosa normal, o que altera a qualidade vocal (Benninger et al., 1996; Isshiki et al., 1999; Rosen, 2000; Thibeault et al., 2002; Hirano et al., 2009). Do ponto de vista histológico, a cicatriz tem como característica um aumento na densidade de colágeno com redução em sua 
organização (cicatriz madura), o que tem impacto negativo na biomecânica da fisiologia fonatória (Rousseau et al.,2003; Thibeault et al.,2002). A rigidez de onda mucosa provocada pela cicatriz pode levar à insuficiência glótica, demandando maior esforço vocal, e clinicamente a voz pode se tornar soprosa, tensa, áspera e por vezes diplofônica (Benninger et al., 1996). O paciente também pode experimentar perda do controle e fadiga vocal (Thibeault et al., 2002).

Hirano e Jackson, em 1995, já sugeriam que a cicatriz de prega vocal era um dos maiores problemas à espera de melhorias no futuro. Quase duas décadas depois, ela continua sendo uma das alterações laríngeas mais difíceis de serem tratadas, uma vez que as abordagens existentes quanto a esta complexa condição ainda têm apresentado resultados inferiores ao desejável e um tratamento eficaz para restaurar a função vocal adequada ainda não foi estabelecido (Isshiki et al., 1999; Rosen, 2000; Hansen, Thibeault, 2006; Allen, 2010; Woodson, 2012).

Muitos cirurgiões utilizam de modo empírico a injeção submucosa de corticosteroide durante a fonomicrocirurgia na tentativa de evitar a formação de cicatriz, apesar da inexistência de evidências científicas que justifiquem seu uso. Acredita-se que os corticosteroides possam influenciar o processo cicatricial por meio da modulação de síntese e maturação do colágeno, inibição da proliferação de fibroblastos e supressão da atividade fagocítica de algumas células do sistema imune (Bless, Welham, 2010). Como a síntese de matriz extracelular ocorre 2 a 3 dias após a injúria tecidual, a fase aguda da cicatrização representa o período crítico no qual a intervenção terapêutica pode, eventualmente, minimizar a formação de cicatriz (Branski et al., 2005a,b). 
Em estudo realizado por Campagnolo et al. (2010), a injeção de dexametasona em prega vocal de coelho imediatamente após lesão cirúrgica levou a uma menor deposição de colágeno no sítio da lesão, durante a resposta inflamatória aguda, sem alteração na quantidade de células inflamatórias. Não se sabe, no entanto, se estes resultados persistem em fases mais tardias do processo cicatricial, levando a eventual atenuação de cicatriz de prega vocal. Acredita-se que, se avanços significativos forem alcançados com medidas profiláticas, a necessidade de se tratar cicatrizes crônicas será cada vez mais rara no futuro. 
2 OBJETIVOS 


\section{OBJETIVOS}

Tendo em vista o benefício potencial dos corticosteroides no processo de cicatrização de prega vocal, este estudo tem como objetivos:

1. Comparar, mediante análise quantitativa, o processo inflamatório de pregas vocais de coelhos submetidas à lesão cirúrgica que receberam injeção submucosa de dexametasona intraoperatória com as pregas vocais que não receberam a injeção (controle), no $7^{\circ}$ e $180^{\circ}$ dia de pósoperatório e entre o $7^{\circ}$ e $180^{\circ}$ dia de pós-operatório.

2. Comparar, por análise quantitativa, a densidade de colágeno de pregas vocais de coelhos submetidas à lesão cirúrgica que receberam injeção submucosa de dexametasona intraoperatória com as pregas vocais que não receberam a injeção (controle), no $7^{\circ}$ e $180^{\circ}$ dia de pós-operatório e entre o $7^{\circ}$ e $180^{\circ}$ dia de pós-operatório.

3. Descrever a organização das fibras colágenas das pregas vocais de coelhos submetidas à lesão cirúrgica que receberam injeção submucosa de dexametasona intraoperatória contrapondo com as pregas vocais que não receberam a injeção (controle), no $7^{\circ}$ e $180^{\circ}$ dia de pós-operatório e entre o $7^{\circ}$ e $180^{\circ}$ dia de pós-operatório. 
3 REVISÃO DA LITERATURA 


\section{REVISÃO DA LITERATURA}

\subsection{Histologia da prega vocal}

Hirano (1974) foi o primeiro autor a descrever a estrutura da prega vocal humana e correlacioná-la à produção vocal. Neste primeiro momento, o autor dividea em duas camadas: cobertura, formada pela mucosa, e corpo, composto por músculo e ligamento vocal.

No ano seguinte, o mesmo autor, ao revisar dados sobre a histologia da prega vocal, passa a dividí-la em cinco camadas: epitélio, camadas superficial, intermediária e profunda da lâmina própria e músculo vocal (Hirano, 1975).

Anos mais tarde, Hirano (1981) descreve a ultraestrutura da lâmina própria da prega vocal como sendo constituída por uma camada superficial com predomínio de fibras colágenas finas, uma camada intermediária com predomínio de fibras elásticas entrelaçadas a algumas fibras colágenas e uma camada profunda com grande densidade de fibras colágenas.

Fundamentados nesses conhecimentos, Hirano e Kakita (1985) introduzem a teoria de corpo-cobertura para a vibração das pregas vocais, na qual a estrutura de cinco camadas descritas anteriormente passa a ser dividida em três: cobertura, composta por epitélio e camada superficial da lâmina própria; região de transição (ligamento vocal), composta pelas camadas intermediária e profunda da lâmina própria; corpo, constituído pelo músculo vocal. De acordo com essa teoria, a 
cobertura desliza sobre uma estrutura mais rígida, o corpo.

A lâmina própria é a estrutura mais importante da prega vocal, uma vez que é a que mais vibra durante a fonação (Ishii et al., 2000). A biomecânica da fonação depende de sua composição: mudanças na lâmina própria podem afetar o desempenho e a elasticidade da prega vocal, que resultam em vibrações assíncronas (Kahane, 1987). O tecido da lâmina própria pode ser dividido em componente celular e matriz extracelular (Labat-Robert et al., 1990; Lander, 1993).

A lâmina própria contém uma variedade de células importantes, que inclui fibroblastos, miofibroblastos e macrófagos (Noordzij, Ossoff, 2006). Em estudo com 22 pregas vocais humanas, Catten et al. (1998) analisam a distribuição de fibroblastos, miofibroblastos e macrófagos na lâmina própria, dividindo sua espessura, de modo arbitrário, em cinco seções iguais. Os autores observam que fibroblastos são as células predominantes e estão distribuídos por todas as camadas, porém são mais abundantes na camada mais profunda da lâmina própria, os macrófagos e miofibroblastos são mais frequentes na camada mais superficial da lâmina própria. Segundo Noordzij e Ossoff (2006), essa localização de macrófagos e miofibroblastos, que são fibroblastos diferenciados em células de reparo, sugere que a prega vocal está constantemente submetida a ciclos de injúrias diminutas e reparos, e que a camada superficial é, provavelmente, a mais acometida.

Segundo Gray et al. (2000), a matriz extracelular é composta por proteínas fibrilares, como colágeno e elastina, e intersticiais, representadas pelos proteoglicanos e glicoproteínas. De acordo com os autores, a distribuição das proteínas fibrosas na lâmina própria influencia as propriedades biomecânicas da 
prega vocal. As fibras colágenas suportam a tensão e o estiramento da prega vocal durante a fonação, enquanto as fibras de elastina permitem a deformidade e o retorno do tecido à sua configuração original (Gray, 2000).

Por meio do método Picrossírius-polarização, Madruga de Melo et al. (2003) descrevem a organização de fibras colágenas na lâmina própria em forma de cesta de vime. Os autores visualizam uma faixa de colágeno estreita, imediatamente abaixo do epitélio da prega vocal, uma faixa mais densa e organizada de colágeno na camada profunda da lâmina própria, superficial ao músculo vocal, e uma rede delicada de fibras na camada intermediária. Os autores acreditam que a configuração das fibras colágenas em forma de cesta de vime confere resistência à lâmina própria ao mesmo tempo em que possibilita o estiramento da prega vocal, para modular a frequência da voz sob a ação da musculatura intrínseca da laringe.

As proteínas intersticiais afetam a viscosidade da lâmina própria e conferem ao tecido a capacidade de amortecimento de impacto (Balazs, Gibbs, 1970). Ao utilizar técnicas de imunocitoquímica, Pawlak et al. (1996) descrevem vários proteoglicanos na lâmina própria de pregas vocais normais, com identificação de agrecan, versican, decorina, fibromodulina e heparina-sulfato. Os autores sugerem que a produção e a manutenção da lâmina própria são realizadas por diferentes células além dos fibroblastos, como macrófagos e miofibroblastos.

\subsection{Cicatrização}

Ao comparar a extensa pesquisa e experiência clínica com cicatrização 
cutânea, constata-se que existem poucos trabalhos que investigam o processo cicatricial de mucosas. A cicatrização da pele é classicamente descrita como a seguir.

A cicatrização de feridas é divida em três fases distintas: inflamação, proliferação e remodelagem (Schilling, 1976). Consiste em um processo dinâmico que envolve a interação de inúmeras cascatas moleculares e celulares que ocorrem simultaneamente e se interpõem, ao invés de uma simples sequência de eventos consecutivos.

3.2.1 Hemostasia e inflamação - início imediatamente após a lesão até $4^{\circ}-6^{\circ}$ dia

Segundo Gourin e Terris (2006), a injúria tecidual causa hemorragia com exposição das plaquetas ao tecido conectivo subendotelial, o que resulta na ativação plaquetária e liberação de inúmeras substâncias vasoativas que provocam vasoconstrição.

As plaquetas, à medida que se agregam, formam um tampão hemostático. $\mathrm{O}$ coágulo que se forma é composto de colágeno, plaquetas, trombina e fibronectina, que liberam citocinas e fatores de crescimento que iniciam a resposta inflamatória (Witte, Barbul, 1997). Os elementos da resposta inflamatória e suas funções encontram-se resumidos no Quadro 1. 
Quadro 1 - Elementos da resposta inflamatória e suas funções

\begin{tabular}{|c|c|}
\hline & Função \\
\hline \multicolumn{2}{|l|}{ Fatores hemostáticos } \\
\hline Fibrina, fibronectina & $\begin{array}{l}\text { Coagulação, quimiotaxia, adesão, suporte para } \\
\text { migração celular }\end{array}$ \\
\hline $\begin{array}{l}\text { Fator XIII (fator estabilizador de } \\
\text { fibrina) }\end{array}$ & Induz quimiotaxia e adesão \\
\hline Fatores de crescimento circulatório & $\begin{array}{l}\text { Regulação de quimiotaxia, mitogênese, } \\
\text { fibroplasia }\end{array}$ \\
\hline Complemento & Atividade antimicrobiana, quimiotaxia \\
\hline \multicolumn{2}{|l|}{ Fatores derivados de plaquetas } \\
\hline Citocinas, fatores de crescimento & Regulação de quimotaxia, mitogênese, fibroplasia \\
\hline Fibronectina & Matriz precoce, ligante para agregação plaquetária \\
\hline Fator ativador de plaqueta (PAF) & Agregação plaquetária \\
\hline Tromboxano A2 & $\begin{array}{l}\text { Vasoconstrição, agregação plaquetária, } \\
\text { quimiotaxia }\end{array}$ \\
\hline Fator plaquetário IV & $\begin{array}{l}\text { Quimiotaxia para fibroblastos e monócitos, } \\
\text { neutraliza atividade da heparina, inibe colagenase }\end{array}$ \\
\hline Serotonina & $\begin{array}{l}\text { Induz permeabilidade vascular, quimiotaxia para } \\
\text { neutrófilos }\end{array}$ \\
\hline Adenosina & $\begin{array}{l}\text { Estimula proliferação e migração celular, induz } \\
\text { agregação plaquetária }\end{array}$ \\
\hline
\end{tabular}

FONTE: Adaptado de Witte e Barbul, 1997

A ação de substâncias vasoativas provoca vasodilatação (principalmente de vênulas), com extravasamento de proteínas plasmáticas, hemácias e leucócitos para o sítio da lesão (Gourin, Terris, 2006).

A fibrina resultante do coágulo, não apenas contribui para a hemostasia, como também serve de suporte para a migração de neutrófilos, monócitos, fibroblastos e células endoteliais (Kurkinen et al., 1980). 
Durante as primeiras 24-48 horas, o infiltrado inflamatório é formado, com predominância, por leucócitos polimorfonucleares (neutrófilos), atraídos para o sítio de lesão pela interleucina 1 (IL-1), fator de necrose tumoral alfa (TNF- $\alpha$ ), fator de transformação de crescimento beta (TGF- $\beta$ ) e fator plaquetário 4 (PF-4) (Bevilacqua et al., 1985; Pohlman et al., 1986).

O predomínio de monócitos ocorre 48-96 horas após a lesão, com sua maturação para macrófagos, que contribuem para a continuidade do debridamento celular (Gourin, Terris, 2006). Os macrófagos ativados mediam a angiogênese (por meio da síntese do fator de crescimento vascular endotelial, VEGF) e fator de crescimento de fibroblastos (TNF- $\alpha$ ), fibroplasia (pela síntese de TGF- $\beta$; fator de crescimento epidermal, EGF; fator de crescimento derivado de plaqueta, PDGF; IL-1 e TNF- $\alpha$ ) e síntese de óxido nítrico (NO) (pela ativação da óxido nítrico sintase pela IL-1 e TNF- $\alpha$ ) (Witte, Barbul, 2002).

\subsubsection{Proliferação - $4^{\circ}$ ao $14^{\circ}$ dia após a lesão}

Segundo Broughton et al. (2006), é nessa fase que ocorre a restauração tecidual, com epitelização, angiogênese, formação do tecido de granulação e deposição de colágeno. Fibroblastos e células endoteliais são as principais células em proliferação nesta fase.

Células epiteliais migram para cima no padrão habitual, se a membrana basal estiver intacta após a lesão tecidual, e as camadas da epiderme são restabelecidas em 2 a 3 dias. Caso a membrana basal tenha sido destruída, as células epiteliais 
localizadas na borda da lesão proliferam e mandam projeções para restabelecer a barreira protetora (Grotendorst et al., 1989; Lawrence, Diegelmann, 1994).

A angiogênese é marcada pela proliferação e migração de células endoteliais a partir de vênulas intactas próximas à lesão, que formam capilares novos (Witte, Barboul, 1997).

Fibroblastos migram para o sítio da lesão em aproximadamente 48-72 horas, originários de células mesenquimais indiferenciadas presentes nos tecidos extravasculares adjacentes (Gourin, Terris, 2006). Em resposta ao PDGF, produzido por plaquetas e macrófagos, os fibroblastos dão início à síntese de uma matriz temporária composta de colágeno tipo III, glicosaminoglicanos e fibronectina (Pierce et al., 1991).

\subsubsection{Maturação e remodelagem - $8^{\circ}$ dia ao $1^{\circ}$ ano após a lesão}

A característica principal dessa fase é a deposição de colágeno. Clinicamente, é a fase mais importante da cicatrização, uma vez que a velocidade, qualidade e quantidade total de deposição de matriz determina a resistência da cicatriz (Witte, Barboul, 1997).

As mudanças na composição da matriz seguem um padrão ao longo do tempo. Inicialmente, é composta predominantemente de fibrina e fibronectina, resultantes da hemostasia e ação dos macrófagos (Kurkinen et al., 1980). A seguir, os fibroblastos sintetizam glicosaminoglicanos, proteoglicanos e outras proteínas, que servem de suporte para a futura deposição de matriz e remodelagem (Barbul, Regan, 
1993). Posteriormente, o colágeno torna-se a proteína principal da cicatriz.

Em uma pele íntegra, o colágeno é composto por 80 a 90\% de colágeno tipo I e 10 a $20 \%$ de colágeno tipo III. No tecido de granulação, o colágeno tipo III corresponde a $30 \%$ e na cicatriz madura volta a corresponder a 10\% (Bailey et al., 1975; Ehrlich, Krummel, 1996).

A estrutura da matriz também sofre alterações com o tempo. A derme normal apresenta padrão em formato de cesta de vime, enquanto na cicatriz as fibras de colágeno estão dispostas paralelamente à pele. Inicialmente essas fibras de colágeno são finas e gradualmente engrossam, e se organizam ao longo da linha de tensão da cicatriz. Essa mudança é acompanhada de aumento da resistência da cicatriz e indica uma correlação positiva entre espessura, orientação da fibra e força tênsil (Doillon et al., 1985).

As fibras colágenas da cicatriz nunca se tornam tão organizadas quanto as da derme intacta, apesar da fase de remodelagem ser longa e durar até um ano (Witte, Barboul, 1997) e não recuperam 100\% de sua força tênsil (Barbul, Regan, 1993).

\subsection{Cicatrização da prega vocal}

A literatura sobre o processo cicatricial da derme é vasta e repleta de evidências que descrevem uma morfologia sem organização específica de elementos celulares e de matriz extracelular (Garg et al., 2000). Ao comparar a extensa pesquisa e a experiência clínica com cicatrização cutânea, existem poucos trabalhos nos quais 
o processo cicatricial de mucosas e das pregas vocais é investigado (Branski et al., 2005b).

Goldstein et al. (1998), em trabalho com coelhos, comparam o processo de cicatrização da mucosa da subglote com o da pele. A reepitelização da mucosa subglótica se inicia no $5^{\circ}$ dia após a lesão e está completa no $14^{\circ}$ dia, a fibroplasia e a fibrose estão presentes na lâmina própria do $7^{\circ}$ ao $21^{\circ}$ dia, com perfil histológico semelhante ao da epiderme e derme, respectivamente. As alterações epiteliais, no entanto, são mais prolongadas na mucosa subglótica.

De acordo com Branski et al. (2006), as pregas vocais possuem uma resistência aparente ao estresse mecânico. Ao contrário da maioria das estruturas do corpo, elas estão sujeitas a um estresse mecânico praticamente contínuo por causa da fonação, mas não apresentam comprometimento estrutural ou fisiológico tão frequente. Os autores acreditam haver duas explicações possíveis: a primeira é que as pregas vocais podem ter uma capacidade regenerativa melhor, nas quais qualquer dano microestrutural à lâmina própria e/ou epitélio possa ser reparado sem que seja desencadeada uma resposta inflamatória plena. Deve existir, entretanto, um limiar que, se ultrapassado, promove o processo de cicatrização em todas suas etapas. A segunda explicação é a organização da microestrutura da lâmina própria de maneira a suportar mais estresse mecânico que outros tecidos, como a derme, por exemplo.

Branski et al. (2005a) descrevem a cicatrização em prega vocal de coelho após lesão cirúrgica com desnudamento de epitélio e lâmina própria em toda sua extensão. A fase proliferativa parece ocorrer por volta do $3^{\circ}$ dia, com observação de importante infiltrado inflamatório, proliferação de células inflamatórias e fibroblastos 
e deposição de uma neolâmina própria. A deposição de uma neomatriz e reepitelização completa é alcançada no $5^{\circ}$ dia. Colágeno mais maduro é observado por volta no $7^{\circ}$ dia.

$\mathrm{Na}$ cicatriz cutânea, o conteúdo de colágeno torna-se estável em aproximadamente 21 dias após a lesão (Lawrence, Diegelmann, 1994). Rousseau et al. (2003), em trabalho com cachorro usado como modelo animal, demonstra que, na prega vocal, o colágeno só se estabiliza aproximadamente 6 meses após a lesão. Antes da maturação, a densidade de colágeno é reduzida na cicatriz de prega vocal (Thibeault et al., 2002).

Em estudo com 11 coelhos submetidos à lesão cirúrgica em prega vocal e análise histológica e reológica após 60 dias da lesão, Thibeault et al. (2002) observam distribuição desorganizada de colágeno por todas as camadas da lâmina própria, com redução na densidade de colágeno, quando comparada ao controle normal, que representa a fase precoce do remodelamento. Encontram, também, redução na densidade de elastina na prega vocal em cicatrização, mas nenhuma diferença em relação ao ácido hialurônico entre os grupos.

Thibeault et al. (2003) encontram redução significativa na densidade de decorina e fibromodulina, e aumento de fibronectina aos 60 dias após a lesão cirúrgica em prega vocal de coelho. A decorina tem o papel de promover a associação lateral das fibras de colágeno a fim de formar feixes de fibras na matriz extracelular. A fibromodulina tem a capacidade de inibir TGF- $\beta$, que estimula a síntese de colágeno (Ignotz, 1986). Com a redução de fibromodulina, espera-se, portanto, aumento na produção de colágeno. A redução de decorina e aumento na 
síntese de neocolágeno poderia explicar a distribuição desorganizada das fibras colágenas observadas em estudo anterior (Thibeault, 2002). A fibronectina tem sido implicada na formação de proteínas de adesão necessárias à ligação de células epiteliais e membrana basal, e migração e replicação de células epiteliais. Os autores acreditam que o aumento de fibronectina é esperado após a lesão, favorecendo a epitelização.

Rousseau et al. (2003) descrevem os aspectos histológicos e reológicos da cicatrização de prega vocal ao $2^{\circ}$ e $6^{\circ}$ mês após a indução de lesão cirúrgica em modelo canino. Há aumento na densidade de procolágeno (precursor do colágeno) no segundo mês, com estabilização de seus níveis no sexto mês. Aos 6 meses, são observados feixes desorganizados de colágeno na lâmina própria, indicando alcance da fase madura do processo cicatricial. As fibras de elastina apresentam-se desorganizadas e com densidade reduzida nos dois períodos. Não são observadas diferenças em relação ao ácido hialurônico.

Verdolini et al. (2003) e Branski et al. (2004, 2005b) relatam a análise de marcadores bioquímicos associados à cicatrização presentes na secreção coletada na superfície da prega vocal como possível método não invasivo de documentar seu processo cicatricial.

\subsection{Corticosteroides}

Os corticosteroides representam uma classe de esteroides produzidos pelo córtex da suprarrenal. Seus efeitos são inúmeros e disseminados e consistem em 
alterações no metabolismo dos carboidratos, lipídios e proteínas, manutenção do equilíbrio hidroeletrolítico, preservação da função normal dos sistemas cardiovascular, imunológico, endócrino, nervoso, renal e músculo esquelético (McKay, Cidlowski, 2000; Schimmer, Parker, 2010). Conferem também ao organismo a capacidade de resistir a situações de estresse, como trauma, infecção, alterações ambientais, entre outras (Sapolsky et al., 2000).

Segundo Schimmer e Parker (2010), os corticosteroides e seus derivados metabolicamente ativos são agrupados de acordo com seus efeitos sobre o metabolismo dos carboidratos (glicocorticoides) e sobre o equilíbrio hidroeletrolítico (mineralocorticoides). Esses efeitos não estão estreitamente relacionados e refletem ações seletivas em receptores distintos.

De acordo com McKay e Cidlowski (2000), a partir de modificações na estrutura química da molécula de cortisol, são produzidos derivados com maior separação entre a atividade glicocorticoide e mineralocorticoide. Essas modificações podem alterar a especificidade e/ou potência mediante alterações na afinidade e atividade intrínseca nos receptores de corticosteroides, assim como alterações na absorção, ligação às proteínas, taxa de transformação metabólica, secreção ou permeabilidade da membrana (Quadro 2). 
Quadro 2: Potências relativas e doses equivalentes de corticosteroides

\begin{tabular}{|lcccc|}
\hline Composto & $\begin{array}{c}\text { Potência } \\
\text { anti-inflamatória }\end{array}$ & $\begin{array}{c}\text { Potência de } \\
\text { retenção de } \\
\mathbf{N a}^{+}\end{array}$ & $\begin{array}{c}\text { Meia-vida } \\
(\mathbf{h})\end{array}$ & $\begin{array}{c}\text { Dose } \\
\text { equivalente } \\
(\mathbf{m g})\end{array}$ \\
\hline Cortisol & 1 & 1 & $8-12$ & 20 \\
Cortisona & 0,8 & 0,8 & $8-12$ & 25 \\
Prednisona & 4 & 0,8 & $12-36$ & 5 \\
Prednisolona & 4 & 0,8 & $12-36$ & 5 \\
Metilprednisolona & 5 & 0,5 & $12-36$ & 4 \\
Triancinolona & 5 & 0 & $12-36$ & 4 \\
Betametasona & 25 & 0 & $36-72$ & 0,75 \\
Dexametasona & 25 & 0 & $36-72$ & 0,75 \\
\hline
\end{tabular}

$\mathrm{Na}^{+}$: sódio; h: hora; mg: miligrama

FONTE: Adaptado de Schimmer e Parker, 2010

Os glicocorticoides atuam como supressores potentes da inflamação, estão entre as classes de fármacos mais prescritos e são utilizados em uma variedade de doenças inflamatórias e autoimunes. Como muitos de seus efeitos fisiológicos e sua ação farmacológica nos diversos tecidos são mediados pelo mesmo receptor, sua eficácia terapêutica pode ser acompanhada de efeitos colaterais (Schimmer, Parker, 2010).

\subsubsection{Mecanismo de ação}

Após sua absorção, pelo menos $90 \%$ do corticosteroide presente no plasma liga-se de modo reversível às proteínas plasmáticas globulina de ligação dos corticosteroides $(\mathrm{CBG})$ ou transcortina e albumina. Apenas a fração livre pode penetrar nas células para mediar seus efeitos (McKay, Cidlowski, 2000; Rang et al., 2001). 
Os corticosteroides interagem com proteínas receptoras específicas presentes nos tecidos-alvo e regulam a expressão de genes responsivos aos corticosteroides. $\mathrm{O}$ receptor de glicocorticoide (GR) está localizado, com predominância, no citoplasma da célula, em uma forma inativa complexada com outras proteínas, como a proteína do choque térmico (HSP) 90, HSP 70 e imunofilina. Após sua ligação com os glicocorticoides, ocorre ativação do GR, que promove a dissociação dessas proteínas e sua translocação para o núcleo, no qual interage com sequências específicas de ácido desoxirribonucleico (DNA) dentro das regiões reguladoras dos genes afetados. As sequências curtas de DNA reconhecidas pelo GR ativado são denominadas elementos responsivos aos glicocorticoides (GRE) e são responsáveis pela especificidade para a indução (transativação) ou inibição (transrepressão) da transcrição gênica (Siegel et al., 1999; Schimmer, Parker, 2010). Entre os genes regulados negativamente estão os da ciclooxigenase 2 (COX-2), da óxido nítrico sintase induzível (NOS-2) e das citocinas inflamatórias, o que parece contribuir significativamente para os efeitos anti-inflamatórios e imunossupressores dos glicocorticoides, conforme ilustrado pela Figura 1 (Nussey, Whitehead, 2001). Em consequência ao tempo necessário à modulação da expressão gênica, os efeitos dos corticosteroides não são em sua maioria imediatos, o que explica a demora observada na prática clínica para a manifestação dos benefícios da terapêutica (Schimmer e Parker, 2010). 


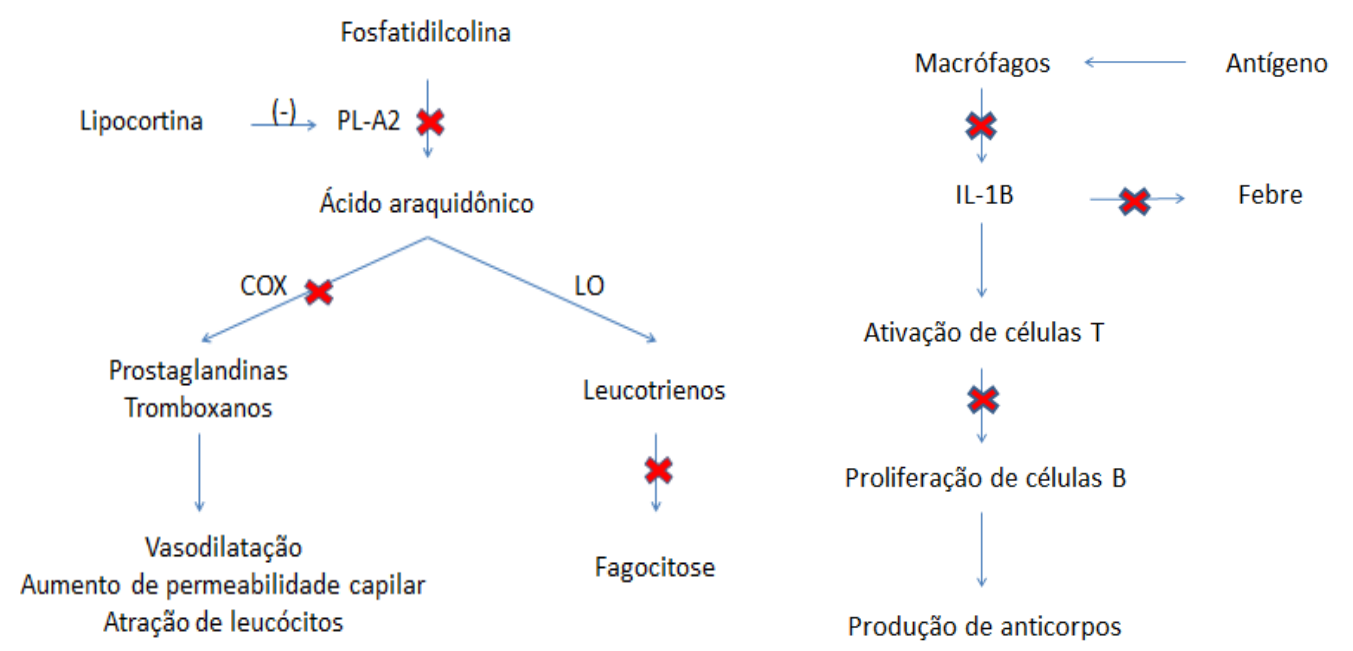

A

B

Figura 1: Efeitos dos glicocorticoides na resposta inflamatória (A) e imune (B). Os glicocorticoides inibem a conversão da fosfatidilcolina em ácido araquidônico por meio da indução de síntese de lipocortina, que inibe a ação da fosfolipase $\mathrm{A}_{2}\left(\mathrm{PL}-\mathrm{A}_{2}\right)$. Assim, ocorre também inibição de produção e ação de leucotrienos. Mediante a inibição da ciclooxigenase (COX), ocorre também inibição da síntese de prostaglandinas e tromboxanos. Por meio do bloqueio de síntese da interleucina $1 \beta$ (IL-1 $\beta$ ), há redução no número de linfócitos $\mathrm{T}$ circulantes e redução de produção de anticorpos

FONTE: Adaptado de Nussey e Whitehead, 2001

Os glicocorticoides também exercem efeito sobre os elementos figurados do sangue: aumentam a quantidade de leucócitos polimorfonucleares circulantes e reduzem a de linfócitos, eosinófilos, monócitos e basófilos (Parrillo, Fauci, 1979; Saavedra-Delgado et al., 1980). Além de seus efeitos sobre a quantidade de linfócitos, suas ações anti-inflamatórias e imunossupressoras ocorrem por meio da alteração da resposta imune dos linfócitos (Schimmer, Parker, 2010).

Os glicocorticoides inibem a produção de fatores envolvidos na geração da resposta inflamatória por inúmeras células (Quadro 3). Assim, há redução na liberação de fatores vasoativos e quimiotáxicos, diminuição na secreção de enzimas lipolíticas e proteolíticas, migração restringida de leucócitos para a área de injúria e, por fim, redução da fibrose (McKay, Cidlowski, 2000; Schimmer, Parker, 2010). 
Quadro 3: Efeitos dos glicocorticoides sobre os componentes da resposta inflamatória e imune

\begin{tabular}{|c|c|c|}
\hline Tipos de células & $\begin{array}{c}\text { Fator envolvido na resposta } \\
\text { inflamatória }\end{array}$ & Comentários \\
\hline \multirow[t]{3}{*}{$\begin{array}{l}\text { Macrófagos e } \\
\text { monócitos }\end{array}$} & $\begin{array}{l}\text { Ácido araquidônico e seus } \\
\text { metabólitos (prostaglandinas } \\
\text { e leucotrienos) }\end{array}$ & $\begin{array}{l}\text { Mediadas pela inibição da COX-2 e da } \\
\text { PL-A } \mathrm{A}_{2} \text { pelos glicocorticoides }\end{array}$ \\
\hline & Citocinas: IL-1, IL-6, TNF- $\alpha$ & $\begin{array}{l}\text { Ocorre o bloqueio da produção e } \\
\text { liberação. As citocinas exercem efeitos } \\
\text { múltiplos sobre a inflamação (p. ex.: } \\
\text { ativação das células } \mathrm{T} \text {, estimulação e } \\
\text { proliferação de fibroblastos) }\end{array}$ \\
\hline & Reagentes de fase aguda & $\begin{array}{l}\text { Incluem o terceiro componente do } \\
\text { complemento }\end{array}$ \\
\hline \multirow[t]{4}{*}{$\begin{array}{l}\text { Células } \\
\text { endoteliais }\end{array}$} & ELAM-1, ICAM-1 & 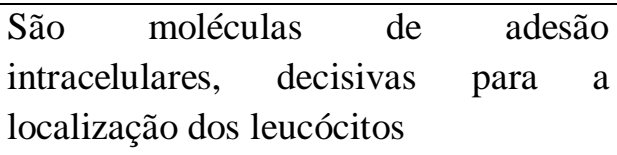 \\
\hline & Reagentes de fase aguda & $\begin{array}{l}\text { Iguais aos descritos para macrófagos e } \\
\text { monócitos }\end{array}$ \\
\hline & Citocinas (p.ex.: IL-1) & $\begin{array}{l}\text { Iguais aos descritos para macrófagos e } \\
\text { monócitos }\end{array}$ \\
\hline & $\begin{array}{lll}\text { Derivados } & \text { do } & \text { ácido } \\
\text { araquidônico } & & \end{array}$ & $\begin{array}{l}\text { Iguais aos descritos para macrófagos e } \\
\text { monócitos }\end{array}$ \\
\hline Basófilos & Histamina e leucotrieno C4 & $\begin{array}{l}\text { Liberação dependente de Ig E inibida } \\
\text { pelos glicocorticoides }\end{array}$ \\
\hline Fibroblastos & $\begin{array}{lll}\begin{array}{l}\text { Metabólitos } \\
\text { araquidônico }\end{array} & \text { do ácido } \\
\end{array}$ & $\begin{array}{l}\text { Iguais aos descritos para macrófagos e } \\
\text { monócitos. Os glicocorticoides } \\
\text { também suprimem a síntese do DNA } \\
\text { induzida pelo fator de crescimento } \\
\text { bem como a proliferação dos } \\
\text { fibroblastos }\end{array}$ \\
\hline Linfócitos & $\begin{array}{l}\text { Citocinas: IL-1, IL-2, IL-3, } \\
\text { IL-6, TNF- } \alpha, \text { GM-CSF, IFN- } \\
\gamma\end{array}$ & $\begin{array}{l}\text { Iguais aos descritos para macrófagos e } \\
\text { monócitos }\end{array}$ \\
\hline
\end{tabular}

COX: ciclooxigenase; PL: fosfolipase; IL: interleucina; TNF: fator de necrose tumoral; ELAM: molécula de adesão leucocitária endotelial; ICAM: molécula de adesão intracelular; Ig: imunoglobulina; GM-CSF: fator de estimulação de colônias de granulócitos-macrófagos; IFN: interferon

FONTE: Schimmer e Parker, 2010 
A resposta de macrófagos a fatores quimiotáxicos é inibida. Ocorre também redução na capacidade de fagocitose de neutrófilos e macrófagos, resultado do efeito estabilizador dos corticosteroides sobre os lisossomos (Drake, Oishi, 1995).

Estudos com cultura de células e modelos animais também mostram influência dos glicocorticoides no "turnover" da matriz extracelular mediante a modulação dos níveis de inúmeras proteínas e enzimas envolvidas em sua biossíntese, e no ácido ribonucleico mensageiro (RNAm) a elas associados (Cutroneo et al., 1981).

Os glicocorticoides "in vitro" têm ação antifibrótica e limitam a ativação de fibroblastos de prega vocal, com redução de sua proliferação e síntese de colágeno induzida por TGF- $\beta$, além dos efeitos sobre o "turnover" da matriz extracelular (Zhou et al., 2011).

Estudos com derme humana e de rato, demonstram a influência dos glicocorticoides na síntese e degradação do colágeno (Oikarinen et al., 1998; Oishi et al., 2002; Durmus et al., 2003). O colágeno é degradado por várias proteinases extracelulares e as mais importantes são as colagenases pertencentes à família das metaloproteinases de matriz. A atividade da colagenase é controlada por inibidores específicos, isto é, os inibidores teciduais de metaloproteinase. O uso de glicocorticoide promove redução nos níveis de tropocolágeno, a unidade proteica que se polimeriza para formar a fibra colágena, de colagenase e dos ácidos ribonucleicos mensageiros (RNAm) que codificam a sua síntese e a dos inibidores teciduais de metaloproteinase (Oikarinen et al., 1998; Oishi et al., 2002). 


\subsubsection{Uso intralesional de corticosteroides em afecções laríngeas}

A administração de corticosteroides no manejo de doenças laríngeas é bem conhecida e bem estabelecida no tratamento de epiglotite, crupe e edema de via aérea superior (Ossoff et al., 1980; Kairys et al., 1989; Rosekrans, 1998; Russell et al., 2004).

As formas mais comumente utilizadas para a administração de corticosteroides são oral, intramuscular e endovenosa. Embora sejam eficazes na redução de edema laringotraqueal e inflamação, a ocorrência de efeitos colaterais impossibilita seu uso por períodos prolongados. Segundo Campagnolo et al. (2008), Tateya (2009) e Mortensen (2010), a injeção local de esteroides permite ao laringologista a opção de administrar localmente uma droga potente, para evitar efeitos colaterais sistêmicos.

Bower et al. (1980) e Krespi et al. (1987) relatam injeção intralesional de esteroide em pacientes com sarcoidose laríngea; McDonald et al. (1982) e Gulati et al. (1997) em granulomas laríngeos por granulomatose de Wegener. A injeção de esteroides também foi descrita para o tratamento de estenose laríngea (Cobb, Sudderth, 1972; Rosen, Vered, 1975; Gnanapragasam, 1979) e alguns autores relatam injeção intralesional de corticosteroides em hemangiomas laríngeos (Hoeve et al., 1997; Bitar et al., 2005; Folia et al., 2007; Saetti R et al., 2008; O et al., 2009; Perkins et al., 2009).

Yanagihara et al. (1964) ilustram, pela primeira vez, os benefícios de injeção submucosa de dexametasona em um grupo de 49 pacientes; 16 com laringite 
crônica, 19 com nódulos vocais e 14 com pólipo vocal. São observados efeitos visíveis em $79 \%$ dos pacientes após a segunda ou terceira injeção. Os autores notam que nódulos fibrosos mais antigos apresentam maior resistência ao tratamento.

Tateya et al. (2003) relatam aumento de "pitch" vocal, tempo máximo de fonação e melhora ao exame endoscópico de pacientes com edema de Reinke leve, submetidos a injeção intracordal de triancinolona. Os mesmos autores (Tateya et al., 2004) relatam desaparecimento de nódulos vocais em 17 pacientes e redução de tamanho em 10, após injeção intralesional do mesmo esteroide em uma série de 37 pacientes.

Mortensen e Woo (2006) relatam aplicação intralesional de metilprednisolona em 34 pacientes com lesões diferentes de prega vocal (nódulos, cisto, pólipo, cicatriz pós-operatória, granuloma). Os autores obtêm sucesso de $87 \%$, definido como mudança significativa na voz a ponto de postergar ou evitar procedimento cirúrgico.

Hsu et al. (2009) referem desaparecimento de pólipo vocal em 59\% dos 24 pacientes submetidos à injeção percutânea de triancinolona em prega vocal, com melhora de parâmetros estroboscópicos em $91 \%$ dos casos. Melhora significativa é observada também na avaliação perceptivo-auditiva do grau de disfonia, rouquidão, soprosidade, astenia e tensão (escala GRBAS), assim como no índice de desvantagem vocal (VHI), tempo máximo de fonação, “jitter” e "shimmer”.

Em estudo prospectivo com 80 pacientes com nódulos vocais, Lee et al. (2011) encontram desaparecimento das lesões em $44 \%$ e melhora em $49 \%$ dos pacientes submetidos à injeção intralesional de triancinolona e avaliados na quarta semana após o procedimento. Observam melhora significativa no VHI, “jitter”, 
“shimmer" e tempo máximo de fonação.

Um estudo multicêntrico conduzido por Woo et al. (2011) com 115 pacientes com edema de Reinke, nódulo, pólipo e cicatriz vocal demonstra remissão total e parcial das lesões em 84,4\% dos pacientes submetidos a injeção intralesional de triancinolona, com melhora significativa na avaliação perceptivo-auditiva e estroboscópica em seguimento de até 6 meses.

Hall et al. (2012) investigam o efeito de injeção intracordal de triancinolona profilática na modulação da resposta inflamatória provocada por fonotrauma agudo e constatam ausência de diferenças significativas na expressão gênica de COX-2, IL$1 \beta$ e TGF- $\beta$ entre a prega vocal tratada e a controle (sem tratamento).

Wang et al. (2013) apresentam a injeção intralesional de triancinolona sob anestesia local como tratamento alternativo para granuloma de processo vocal após falha terapêutica de tratamento clínico com inibidor de bomba de prótons por 3 meses. O procedimento foi realizado mensalmente por até três vezes em 10 pacientes, até que a redução em pelo menos $90 \%$ do granuloma tenha sido observada ou melhora de sintomas clínicos tenha sido relatada. Durante o período de acompanhamento de 6 meses, todos os pacientes apresentaram melhora objetiva da lesão e subjetiva dos sintomas.

Os corticosteroides também têm sido estudados como terapia adjuvante em microcirurgia laríngea na tentativa de evitar a formação de cicatriz.

Bouchayer e Cornut (1988) descrevem o uso de injeção de hidrocortisona em pregas vocais humanas ao final de fonomicrocirurgia para exérese de lesões 
benignas, com resultados favoráveis como melhor maleabilidade da prega vocal, fechamento glótico e qualidade vocal.

Coleman et al. (1999) investigam o efeito de injeção de triancinolona na cicatrização de "microflap" lateral em laringe canina e não encontram diferenças perceptíveis em avaliação videoestroboscópica entre pregas vocais tratadas e não tratadas na $2^{\mathrm{a}}, 4^{\mathrm{a}}$ e $6^{\mathrm{a}}$ semana após a cirurgia, apesar do atraso na resposta cicatricial provocado pelo esteroide.

Em 2007, Alencar et al. injetam dexametasona imediatamente antes da realização de "microflap" em prega vocal de suínos e observam diminuição não significativa na deposição de colágeno total no grupo operado com corticoide, em relação ao grupo operado sem a substância, em avaliação realizada 30 dias após o procedimento.

O estudo conduzido por Campagnolo et al., em 2010, demonstra haver menor deposição de colágeno na cicatriz de pregas vocais de coelho tratadas com dexametasona após indução de lesão cirúrgica, quando avaliadas no $3^{\circ}$ e $7^{\circ}$ dia de pós-operatório.

Apesar dos benefícios demonstrados por alguns dos estudos acima citados, existem algumas complicações possíveis resultantes da injeção de corticosteroides. Essas complicações, associadas ao uso injetável de corticosteroides em prega vocal, incluem atrofia muscular e glandular, caso a injeção seja feita em grande profundidade (Mortensen, Woo, 2006).

Para avaliar essas complicações, Jin et al. (2013) realizam experimento com injeção de triancinolona, em diferentes concentrações, em prega vocal de coelho e 
observam atrofia muscular e redução na espessura do epitélio nas pregas vocais tratadas com esteroide, independentemente da dose injetada. Diferenças na resposta inflamatória, atrofia glandular e deposição de colágeno não são observadas entre a prega vocal tratada e a controle.

Andrade Filho e Rosen (2003) relatam o surgimento de uma placa esbranquiçada subepitelial após injeção de triancinolona em cicatriz de prega vocal em dois pacientes, sem qualquer impacto na vibração da onda mucosa. Em virtude disso, Sataloff et al. (2007) recomendam uso corticosteroides em solução aquosa transparente, como dexametasona, em detrimento de preparações à base de óleo e com aspecto esbranquiçado. Os autores acreditam que as partículas brancas suspensas em soluções com aspecto leitoso podem precipitar e formar uma placa esbranquiçada que pode levar meses para desaparecer.

A duração do efeito da injeção intralesional do esteroide ainda é incerto. Mortensen e Woo (2006) relatam benefício por 4 a 12 semanas.

\subsection{O coelho como modelo animal para experimentação em laringologia}

As mudanças nos elementos da matriz extracelular e seus efeitos nas propriedades viscoelásticas do tecido, decorrentes da cicatriz, são difíceis de serem estudadas em seres humanos com controle experimental adequado. Destarte, modelos animais proporcionam oportunidade única para investigação sistemática de regimes de tratamento que minimizem ou corrijam a cicatriz de prega vocal (Thibeault et al., 2002). 
Laringes de animais, além disso, são mais fáceis de serem obtidas que laringes humanas e o tempo do estudo pode ser mais bem controlado (Kurita et al., 1983). Contudo, até o momento, não há um modelo ideal, pois nenhum modelo animal apresenta anatomia laríngea idêntica à humana (Garrett et al., 2000) e existem diferenças no tamanho da prega vocal, estrutura da lâmina própria e elementos da matriz extracelular entre os animais (Bless, Welham, 2010).

Segundo Bless e Welham (2010), a escolha do modelo animal não é fundamentada somente em suas características físicas, mas também nos aspectos práticos envolvidos, como tamanho do animal, recursos disponíveis, custo e manutenção do animal.

Segundo Rousseau et al. (2004), o coelho consiste em um modelo economicamente eficiente para estudos em longo prazo de cicatrização de prega vocal e demonstra propriedades teciduais similares à humana.

Do ponto de vista ultraestrutural, a prega vocal de coelho é relativamente similar à humana, com lâmina própria em camadas diferenciadas e músculo tireoaritenoideo (Thibeault et al., 2002). Kurita et al. (1983) descrevem a lâmina própria com duas camadas, presença de elementos de matriz extracelular, como elastina e colágeno, e ausência de estrutura comparável ao cone elástico. A camada superficial é pobre em componentes fibrosos e a camada profunda é densa em fibras colágenas e de elastina.

Segundo Thibeault et al. (2002), há similaridade nas propriedades viscoelásticas de prega vocal de coelho e humana normais. Os mesmos autores lembram como limitação ao seu uso o fato de ser um animal desprovido de 
capacidade fonatória, que é submetido a menos forças mecânicas. Bishop (1998), Chiquet (1999) e Parsons et al. (1999) demonstram em seus estudos que forças mecânicas externas podem influenciar a expressão gênica de elementos da matriz extracelular, síntese e "turnover" do colágeno.

\subsection{Uso do método de Picrossírius-polarização para histomorfometria do colágeno}

Sirius Red é um corante ácido que marca o colágeno por meio da reação de seus grupos sulfônicos ácidos com os grupos de aminoácidos básicos presentes na molécula de colágeno. As moléculas do Sirius Red são alongadas e, ao reagirem com o colágeno, promovem um aumento de sua birrefringência natural, por meio do alinhamento paralelo de suas moléculas com o maior eixo de cada molécula de colágeno (Junqueira et al., 1979).

A coloração com Sirius Red isoladamente, entretanto, não é específica para o colágeno. O uso de microscopia de polarização confere ao método não somente especificidade, mas aumenta consideravelmente sua sensibilidade e resolução (Junqueira et al., 1979; Montes e Junqueira, 1991).

Junqueira et al. (1978) propõem diferenciar os vários tipos de colágeno a partir da observação de diferentes cores e intensidades da birrefringência de cortes histológicos estudados pelo método acima descrito. Segundo os autores, o colágeno tipo I aparece como fibras grossas, amarelas ou vermelhas, fortemente birrefringentes, enquanto o colágeno tipo III aparece na forma de fibras finas, 
esverdeadas, fracamente birrefringentes. Já o colágeno tipo II não forma fibras e mostra birrefringência fraca e com cores variáveis.

Em 1982, Junqueira et al. sugerem que as diferenças na birrefringência das fibras colágenas são influenciadas pela espessura e não por uma interação química específica entre o Sirius Red e o tipo de colágeno. Uma redução gradual na espessura resulta em diminuição na intensidade de birrefringência e mudança de cor do vermelho, para o amarelo e, finalmente, para o verde.

Segundo Dayan et al. (1989), a espessura da fibra de colágeno não é o único fator envolvido na determinação das cores da birrefringência. $\mathrm{O}$ arranjo estrutural das moléculas de colágeno desempenha papel importante: fibras avermelhadas correspondem a moléculas densamente agrupadas, enquanto fibras esverdeadas a moléculas frouxamente arranjadas. 
4 MÉTODOS 


\section{MÉTODOS}

\subsection{Aspecto ético}

Este estudo foi aprovado pela Comissão de Ética para Análise de Projetos de Pesquisa (CAPPesq) do Hospital das Clínicas da Faculdade de Medicina da Universidade de São Paulo (HCFMUSP), sob o protocolo de pesquisa $n^{0}$ 1308/09 (Apêndice).

Por se tratar de trabalho com experimentação em animais, os procedimentos realizados seguiram as normas éticas postuladas pelo Colégio Brasileiro de Experimentação Animal (COBEA), instituição afiliada à "International Council for Laboratory Animal Science” e à Lei Federal n ${ }^{\circ} 11794$ de 8 de outubro de 2008 (Brasil, 2008).

\subsection{Amostra}

Foram utilizados 14 coelhos albinos da raça "New Zealand", todos sadios, jovens e machos, com massa corporal entre $3000 \mathrm{~g}$ e $3800 \mathrm{~g}$, fornecidos pelo Centro de Bioterismo da Faculdade de Medicina da Universidade de São Paulo (FMUSP) ( $n^{\mathrm{o}}$ DTAEP 020/101).

A amostra foi dividida aleatoriamente em dois grupos, com sete coelhos cada. Todos os animais foram submetidos ao mesmo procedimento cirúrgico e os grupos 
diferiram apenas quanto ao tempo em que foi realizado seu sacrifício. Os animais do Grupo I foram sacrificados no $7^{\circ}$ dia de pós-operatório, enquanto que os animais do Grupo II, no $180^{\circ}$ dia.

O procedimento cirúrgico, eutanásia e coleta de material foram realizados no centro cirúrgico do Centro de Bioterismo da FMUSP.

\subsection{Procedimento pré-operatório}

Os animais foram mantidos em jejum por três horas antes do procedimento cirúrgico, pesados e identificados com tatuagem na orelha esquerda.

\subsection{Anestesia}

Os animais foram sedados com xilazina $(5 \mathrm{mg} / \mathrm{kg})$ e quetamina $(50 \mathrm{mg} / \mathrm{kg})$ via intramuscular e mantidos sob ventilação espontânea.

Após constatar que o animal estava sedado, foi realizada antibioticoterapia profilática com 300.000UI de benzilpenicilina procaína e 100.000UI de benzilpenicilina potássica diluídas em $3 \mathrm{~mL}$ de água destilada e aplicados $0,4 \mathrm{~mL}$ por dose, via intramuscular. 


\subsection{Procedimento cirúrgico}

Os animais foram posicionados sobre a mesa cirúrgica, com fixação das patas traseiras à mesma, em decúbito dorsal horizontal e hiperextensão cervical conforme a Figura 2.

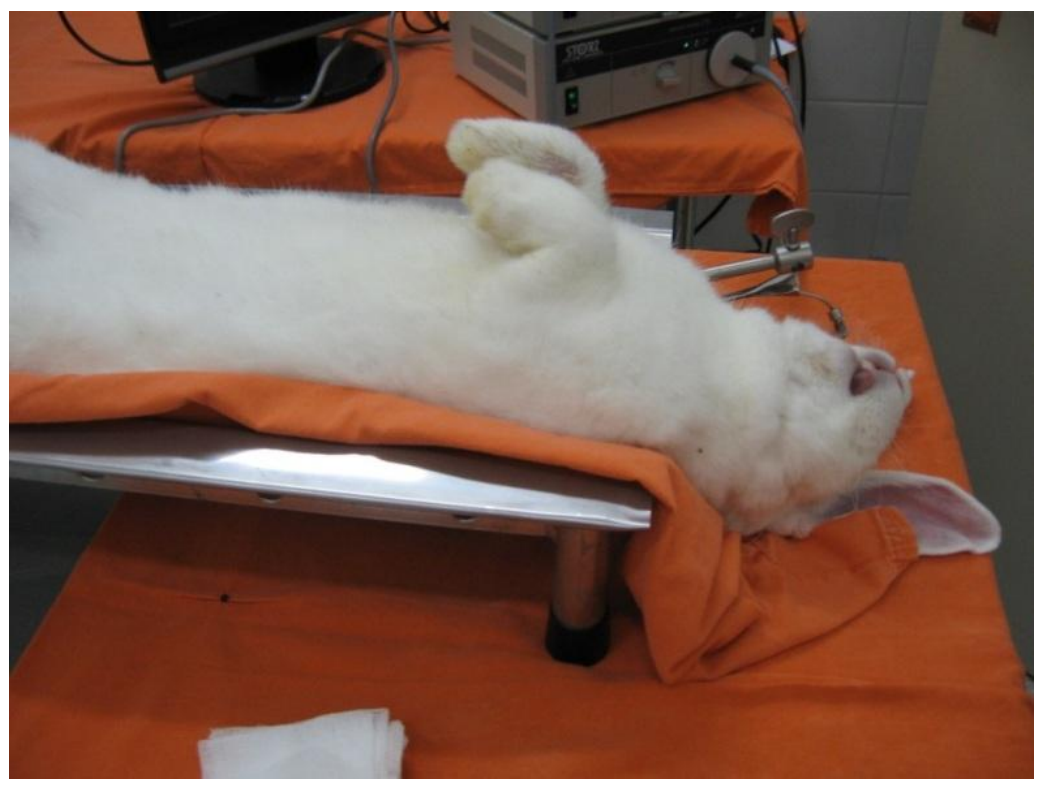

Figura 2: Posicionamento do animal na mesa cirúrgica

A laringoscopia direta foi realizada com auxílio de um laringoscópio de suspensão (confeccionado por Ferrari Medical, São Paulo, SP) desenvolvido de acordo com o modelo de um espéculo nasal de Killian e modificado, para adaptar-se à anatomia dos coelhos (Figuras 3, 4), nos aspectos seguintes:

- As lâminas foram afinadas próximo à base e alongadas $(10,5 \mathrm{~cm}$ de extensão), de modo a obter melhor exposição da glote; 
- Uma articulação e um pino giratório ao lado da mesma foi adaptado, na base lateral do espéculo, o que possibilita manter o espéculo aberto. Essa articulação se conecta a outra que foi fixada à placa de metal, viabilizando sua fixação na altura desejada. Desse modo, o pesquisador tem suas duas mãos livres para execução do procedimento: a mão esquerda segura o telescópio e a direita, a pinça cirúrgica.

- Um canal para introdução de guia de luz de fibra óptica removível e conectado à fonte de luz (Xenon Nova 300, Karl Storz ${ }^{\circledR}$, Alemanha) foi adaptado na base inferior do espéculo.

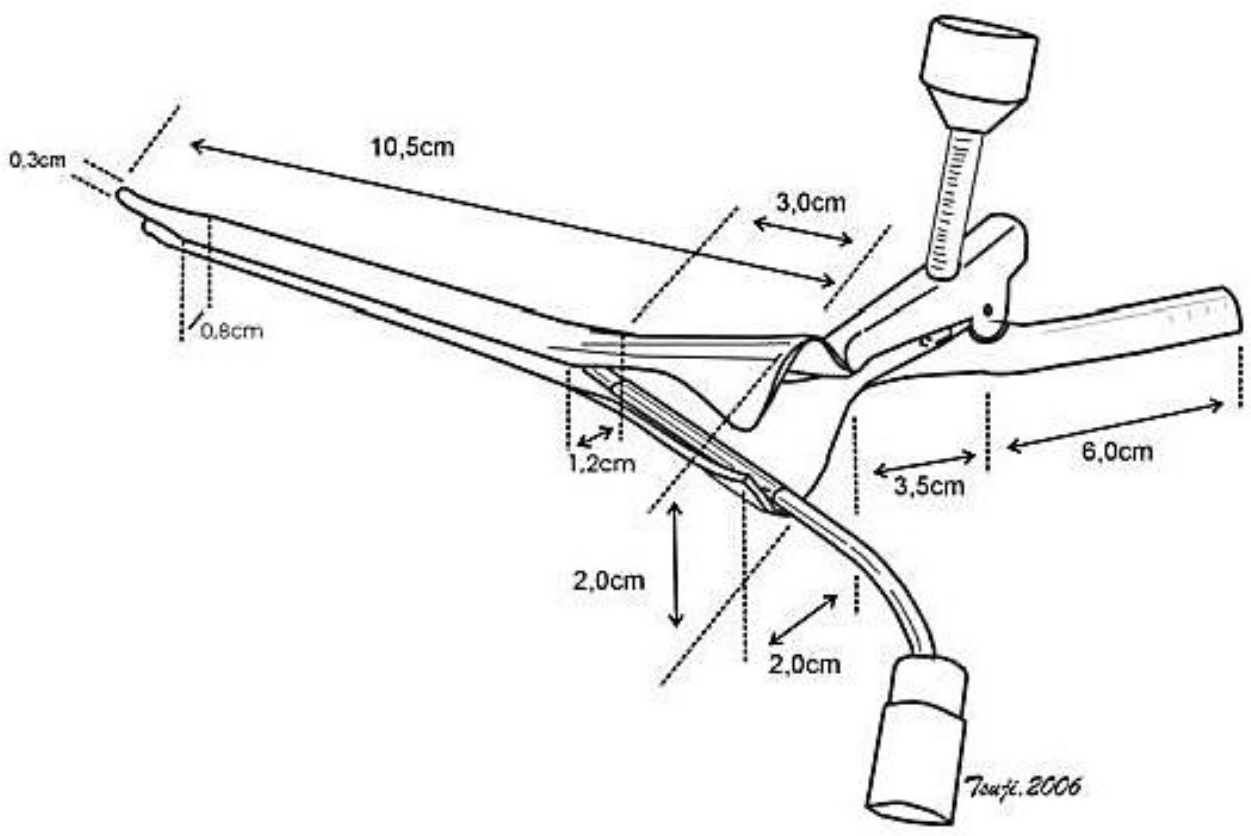

Figura 3: Desenho esquemático ilustra o laringoscópio e suas dimensões 

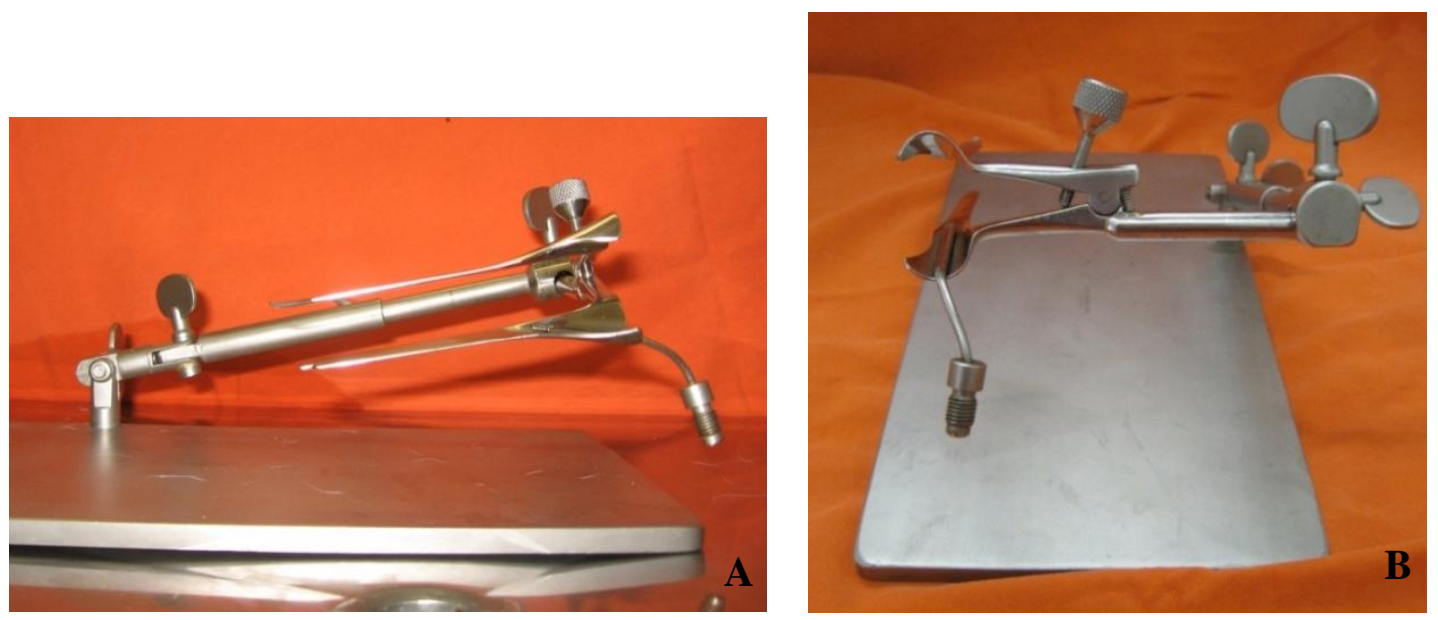

Figura 4: Imagens do laringoscópio: (A) visão lateral; (B) visão anterior

Após a laringoscopia, um endoscópio rígido de $0^{0}$ (Karl Storz ${ }^{\circledR}, 4 \mathrm{~mm}$, Alemanha) acoplado a uma microcâmara (Karl Storz ${ }^{\circledR}$, Alemanha) foi introduzido para obtenção de imagens em um monitor de vídeo.

Com visualização adequada da glote do animal, uma pinça bisturi com a ponta em lâmina em formato de foice, desenvolvida para o presente estudo (Marcançoli, São Paulo - SP) e com um reparo transversal que delimita e padroniza em $2 \mathrm{~mm}$ a profundidade da penetração na prega vocal (Figura 5), foi introduzida para criar a lesão cirúrgica. Foi realizada incisão na superfície superior de ambas as pregas vocais, paralela à sua borda livre, no sentido anteroposterior e em toda sua extensão (Figura 6). A seguir, uma pinça tipo agulha (desenvolvida pela Ferrari Medical - São Paulo - SP), com ponta biselada e reparo a $2 \mathrm{~mm}$ dessa ponta, para delimitar e padronizar a profundidade da injeção, foi introduzida para infiltração de dexametasona, no terço posterior da região, lateral à lesão, apenas da prega vocal direita (Figura 7). A agulha (diâmetro 0,4mm) foi acoplada a uma seringa de insulina 
para padronizar o volume de dexametasona $(0,1 \mathrm{~mL})$ a ser injetado. A concentração de dexametasona utilizada foi de $4 \mathrm{mg} / \mathrm{mL}$.

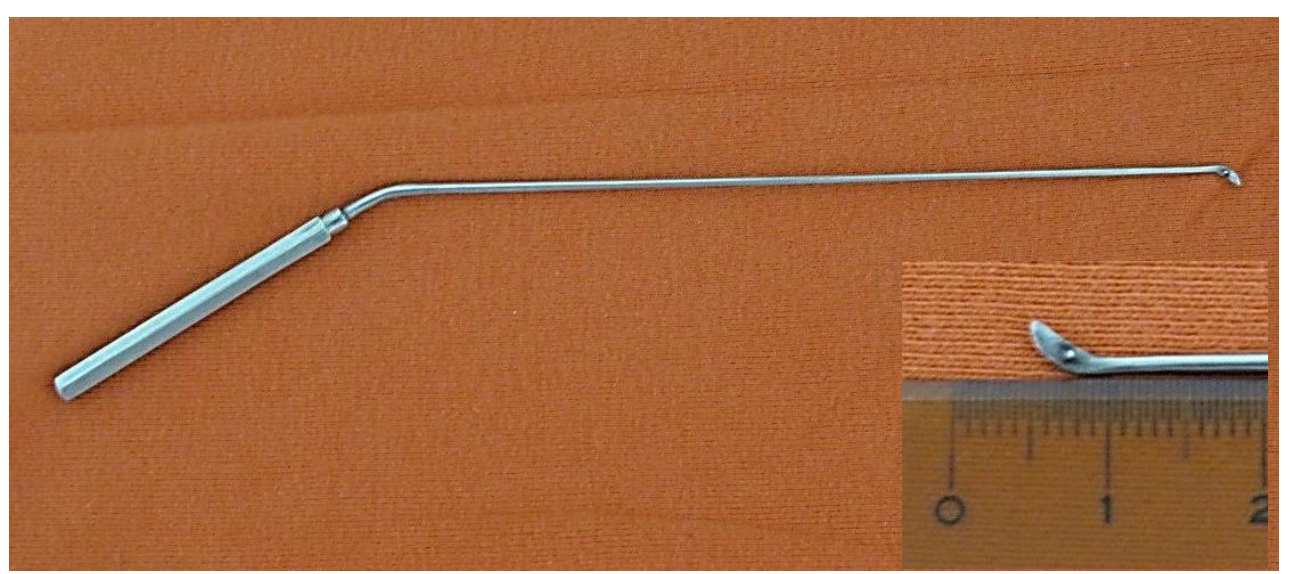

Figura 5: Imagem da pinça bisturi. Em detalhe, medida do reparo

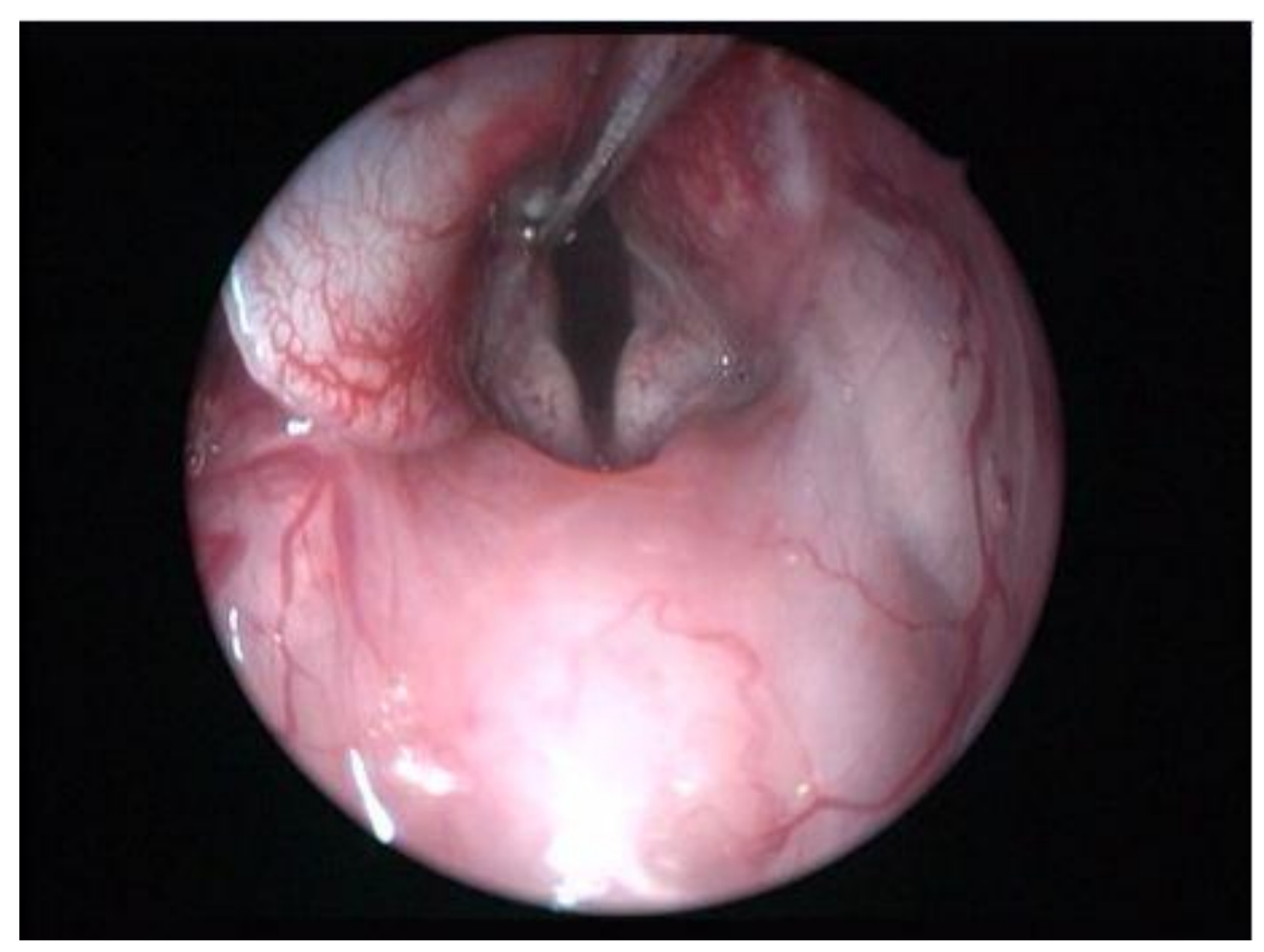

Figura 6: Imagem da incisão em prega vocal esquerda 


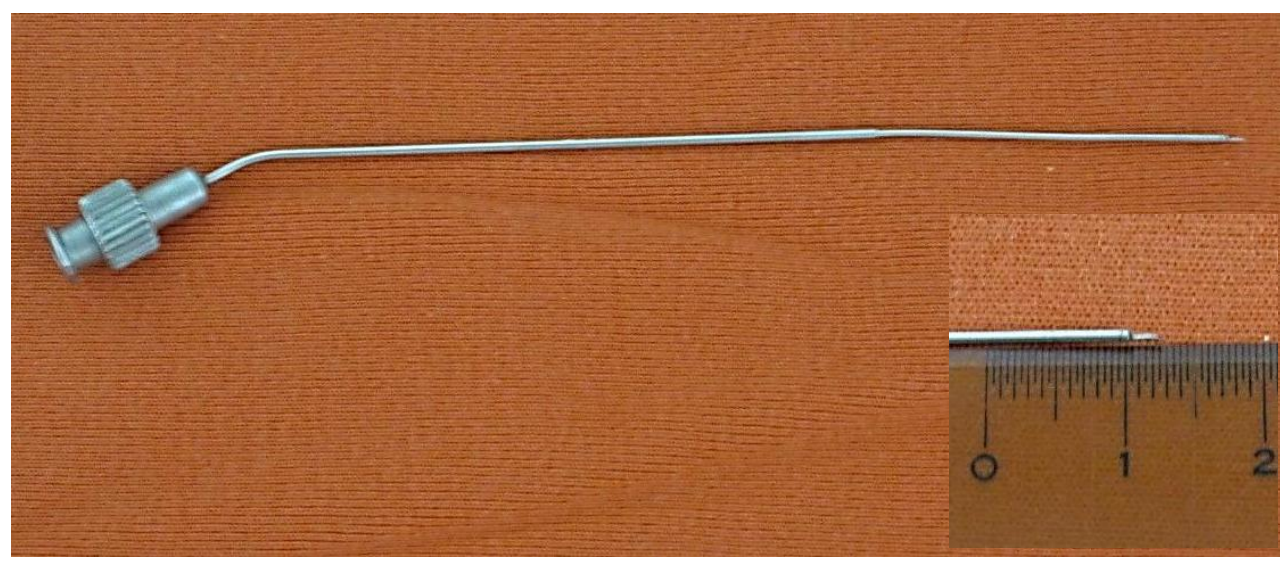

Figura 7: Imagem da agulha de injeção. Em detalhe, medida do reparo

\subsection{Procedimento pós-operatório}

Após o término do procedimento cirúrgico, os animais permaneceram na sala cirúrgica para recuperação anestésica, sob a supervisão do pesquisador por pelo menos 1 hora. A seguir, foram encaminhados para acomodação em gaiolas individuais no Centro de Bioterismo da FMUSP, e foram mantidos em ambiente adequado, com cuidados diários, sob a supervisão de zootecnistas e veterinários, com água e ração "ad libitum”.

\subsection{Eutanásia dos animais e isolamento das laringes}

Após alcançar o tempo de observação determinado para cada grupo, os animais foram anestesiados conforme descrito anteriormente e sacrificados com injeção endovenosa de cloreto de potássio $(\mathrm{KCl})$ a $20 \%$. 
Procedeu-se à incisão cervical anterior do coelho para retirar a laringe em bloco único, desde a base da língua até terceiro ou quarto anel traqueal (Figura 8). A seguir, as peças foram cuidadosamente dissecadas, com remoção das partes moles e isolamento do arcabouço laríngeo. A laringe foi aberta por meio de incisão longitudinal posterior entre as cartilagens aritenóides e uma incisão anterior mediana, obtendo-se duas hemilaringes. Cada hemilaringe foi incisada em sentido transversal, acima e abaixo da região glótica, e depois perpendicular à borda livre da prega vocal, entre o processo vocal e o terço posterior da prega vocal.

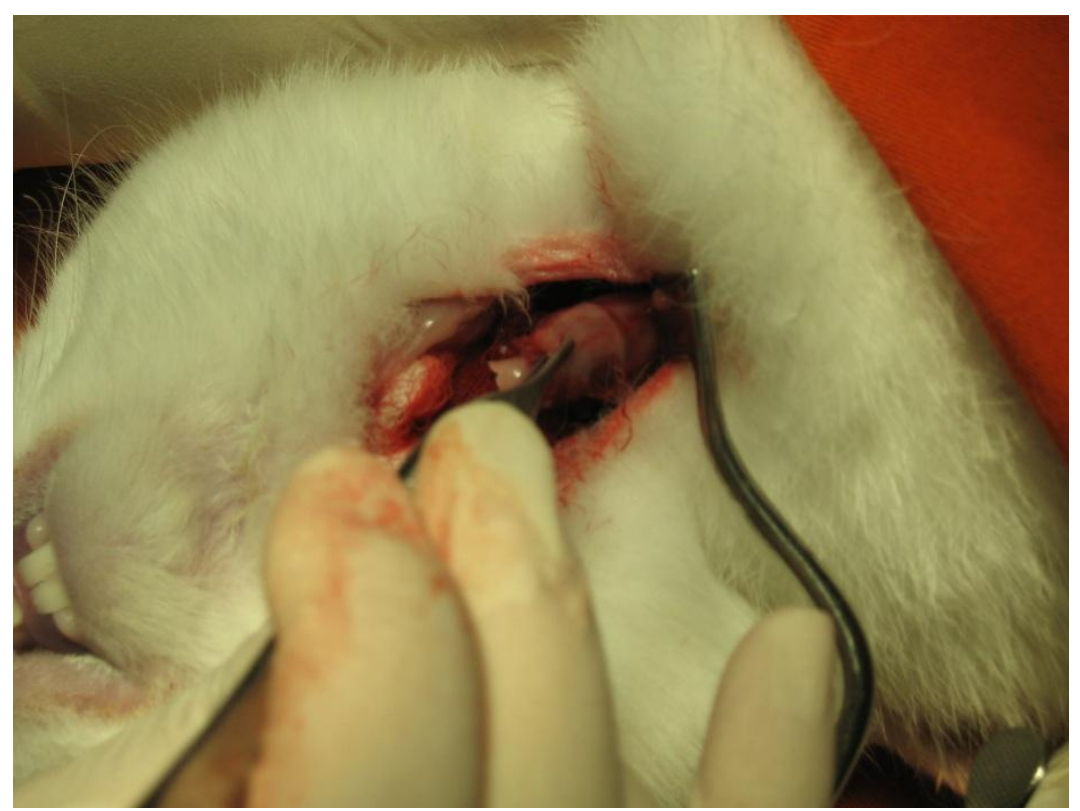

Figura 8: Cervicotomia com identificação da laringe

As peças foram acomodadas em cassetes, identificadas para posterior avaliação cega, fixadas em formol a $10 \%$ por 8 horas, em seguida, acondicionadas em álcool a 70\% e encaminhadas para o Laboratório de Histopatologia da FMUSP para processamento. 


\subsection{Preparação histológica}

No Laboratório de Histopatologia da FMUSP, as peças foram desidratadas em concentrações gradativas de álcool etílico, diafanizadas em xilol, impregnadas e incluídas em parafina fundida, e tratadas em estufa a $60^{\circ} \mathrm{C}$.

Os blocos de parafina foram cortados em lâminas no plano coronal, com micrótomo em sentido póstero-anterior, com espessuras de $3 \mu \mathrm{m}$ cada. Foram realizados cortes seriados, com confecção de quantidade variável de lâminas para cada peça, até que fosse obtida a melhor visualização da lâmina própria da prega vocal a ser analisada. As lâminas foram coradas com hematoxilina-eosina (HE) para análise quantitativa do infiltrado inflamatório, edema, hemorragia lesional e perilesional, e com Picrossírius para análise quantitativa e descritiva das fibras colágenas da lâmina própria.

O preparo das lâminas, desde o corte da peça até a coloração, foi realizado por um mesmo técnico, de modo a manter uma padronização.

\subsection{Análise morfométrica}

4.9.1 Quantificação do infiltrado inflamatório, edema e hemorragia

As lâminas coradas com HE foram utilizadas para análise e comparação do processo inflamatório, edema e hemorragia lesional e perilesional das pregas vocais 
direitas (que receberam injeção de dexametasona) e das pregas vocais esquerdas (utilizadas como controles do modelo).

A quantificação das diferentes variáveis em análise foi realizada mediante a técnica do "point-counting" (Gundersen et al., 1988), que utiliza um retículo com 100 pontos gerado por um analisador de imagem (Figura 9). O sistema utilizado consiste de uma câmera digital Nikon DS-Ril (Nikon Instruments Inc., Tokio, Japão) acoplada a um microscópio Nikon Eclipse 50i (Nikon Instruments Inc., Tokio, Japão) e um computador Pentium-III 3GHz equipado com o "software" "Image ProPlus” 7.0 (Media Cybernetics Inc, Bethesda, Maryland, Estados Unidos). Em cada lâmina, sob visualização microscópica, com magnificação de 400 vezes, foram selecionados, aleatoriamente, 10 campos (Figura 10). As imagens observadas no microscópio foram capturadas e processadas digitalmente pelo "software" e visualizadas no monitor. Em seguida, o "software" gerou um retículo com 100 pontos.

Para corrigir os dados, tendo em vista que a área de interesse do estudo é a lâmina própria, não foram considerados os pontos que não incidiam sobre a mesma (exemplo: músculo, epitélio, áreas de artefato).

Os valores foram expressos em porcentagem de pontos positivos do total de pontos em área de interesse da prega vocal, segundo a fórmula:

$$
\mathbf{P}_{\text {POntos positivos }}=(\mathbf{P i} \times \mathbf{1 0 0}) / \mathbf{P}_{\text {lâmina própria }}
$$

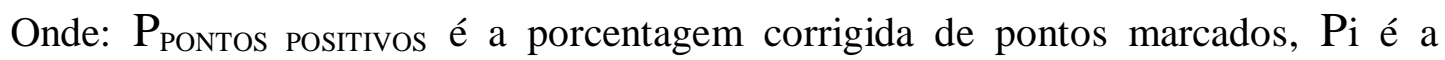
quantidade de pontos que incidem sobre a célula (linfócitos, monócitos, macrófagos, 
neutrófilos e plasmócitos) ou área de interesse (edema e hemorragia) e $\mathrm{P}_{\text {lâmina própria }}$ é o total de pontos que incidem sobre a lâmina própria.

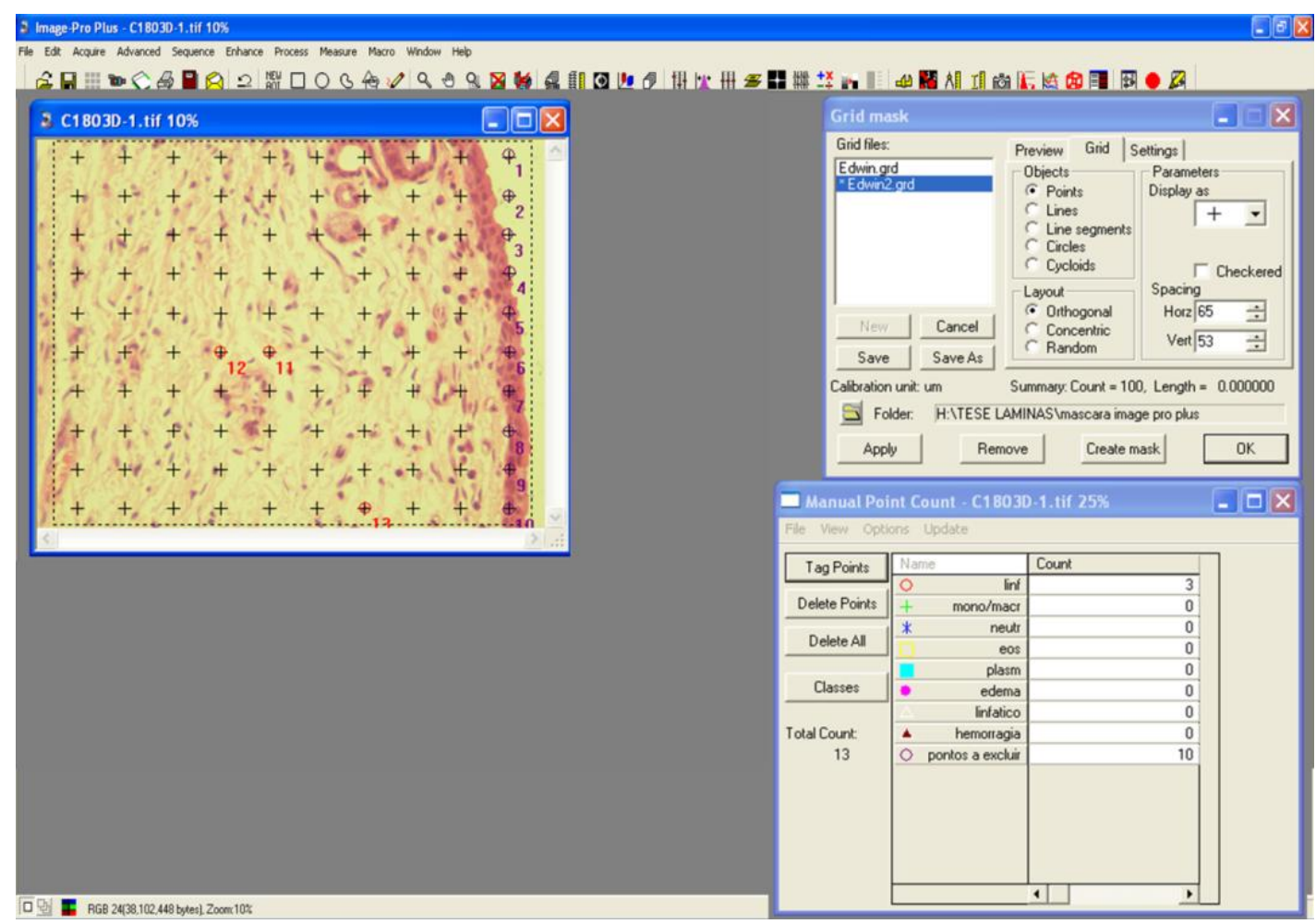

Figura 9: Interface do programa de análise digital de imagem que mostra a fotomicrografia com corte histológico de prega vocal, corado em HE, e aplicação de retículo para quantificação de células inflamatórias. Aumento de 400x 


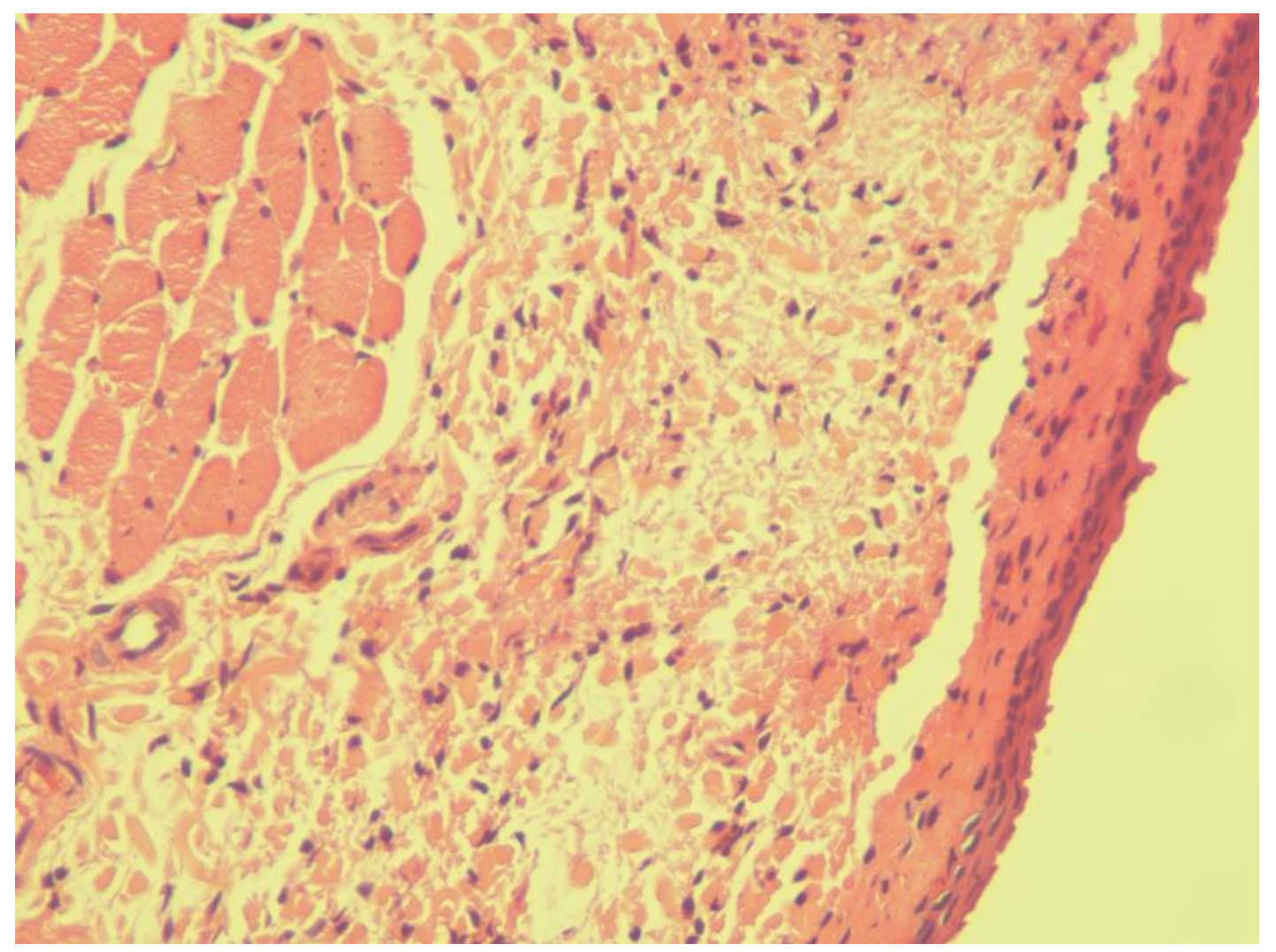

Figura 10: Fotomicrografia de corte histológico de prega vocal corado em HE. Aumento de 400x

\subsubsection{Análise do Sistema de Fibras de Colágeno}

As fibras de colágeno, quando observadas sob a microscopia de luz convencional não polarizada, aparecem vermelhas sobre fundo amarelado (Figura 11A). A técnica de Picrossírius permite a quantificação das fibras de colágeno, caracterizando-as simplesmente em fibras grossas (vermelhas, amarelas ou alaranjadas) e finas (verdes), segundo a tonalidade de birrefringência quando analisadas sob a luz polarizada (Figura 11B). 

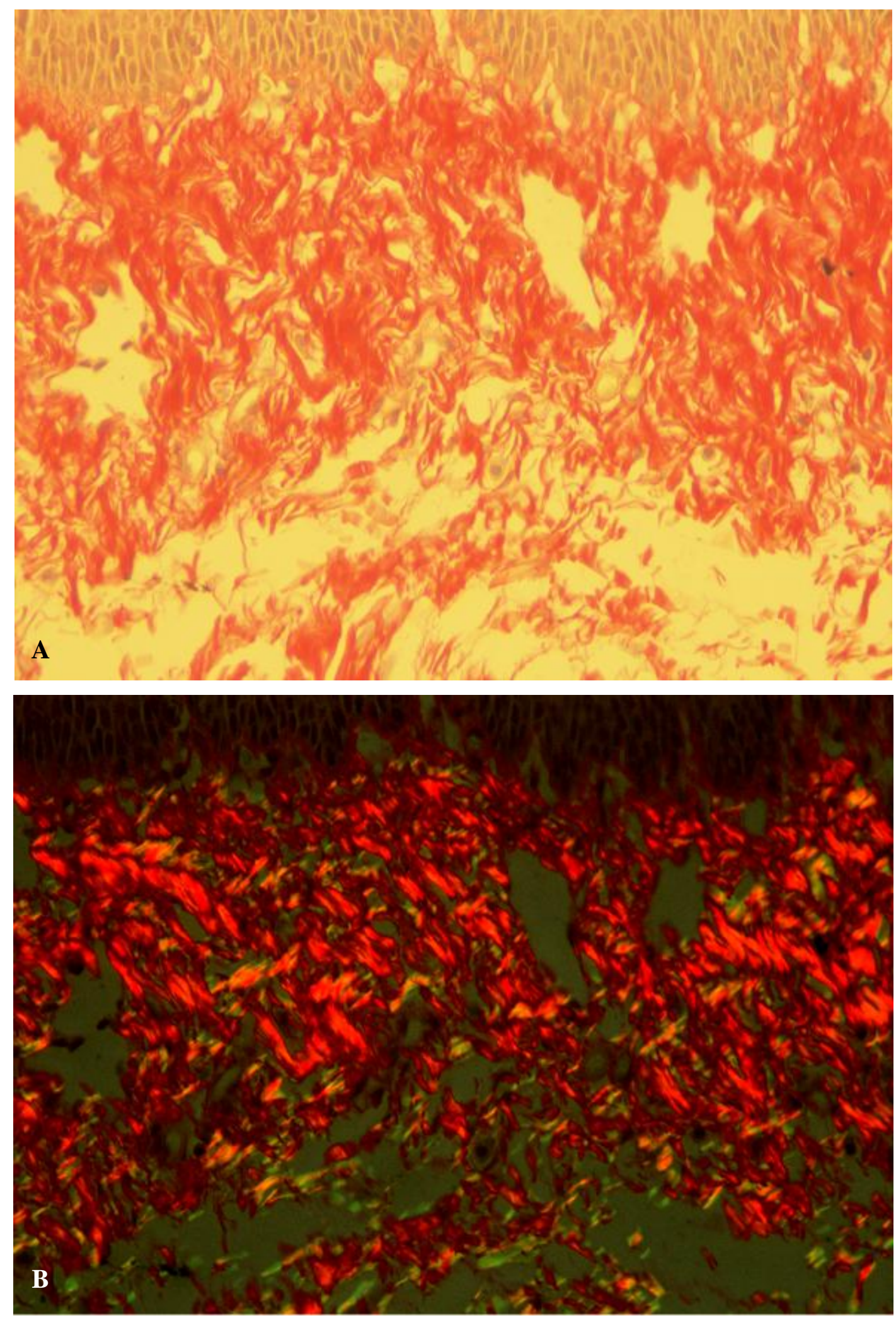

Figura 11: Fotomicrografia de corte histológico corado com Picrossírius e visualizado sob luz convencional não polarizada (A) e polarizada (B). Aumento de 400x 
Para a análise das lâminas coradas com Picrossírius foi utilizado um analisador de imagem acoplado a um microscópio óptico equipado com um polarizador de luz. O sistema empregado foi o mesmo descrito anteriormente. Em cada lâmina, visualizada em microscópio com magnificação de 400 vezes, foram selecionados, aleatoriamente, 10 campos. O brilho, o contraste e a luminosidade da imagem foram ajustados de modo que, sob a luz polarizada, as fibras de colágeno fossem facilmente identificadas como birrefringentes, independentemente de sua cor. Os mesmos valores de luminosidade, brilho e contraste foram utilizados para todas as medidas. As imagens produzidas pelo microscópio foram capturadas e processadas digitalmente pelo "software" e visualizadas no monitor.

Com o auxílio do "software", a área total de colágeno na amostra foi medida em micrômetros quadrados, mediante reconhecimento das frequências de luz correspondentes às fibras birrefringentes (Figuras 12 e 13). O mesmo padrão de frequências foi utilizado para todas as medidas, evitando-se assim qualquer viés na determinação da área de colágeno, por campo analisado. Artérias e veias foram cuidadosamente evitadas durante as medidas. $\mathrm{Na}$ mesma amostra, foi determinada também a área total expressa em $\mu \mathrm{m}^{2}$, correspondente à lâmina própria (Figura 14). Após serem feitas essas medidas, foi obtida a razão da área de colágeno em relação à área de tecido do campo analisado, e este valor, posteriormente, foi expresso em porcentagem. 


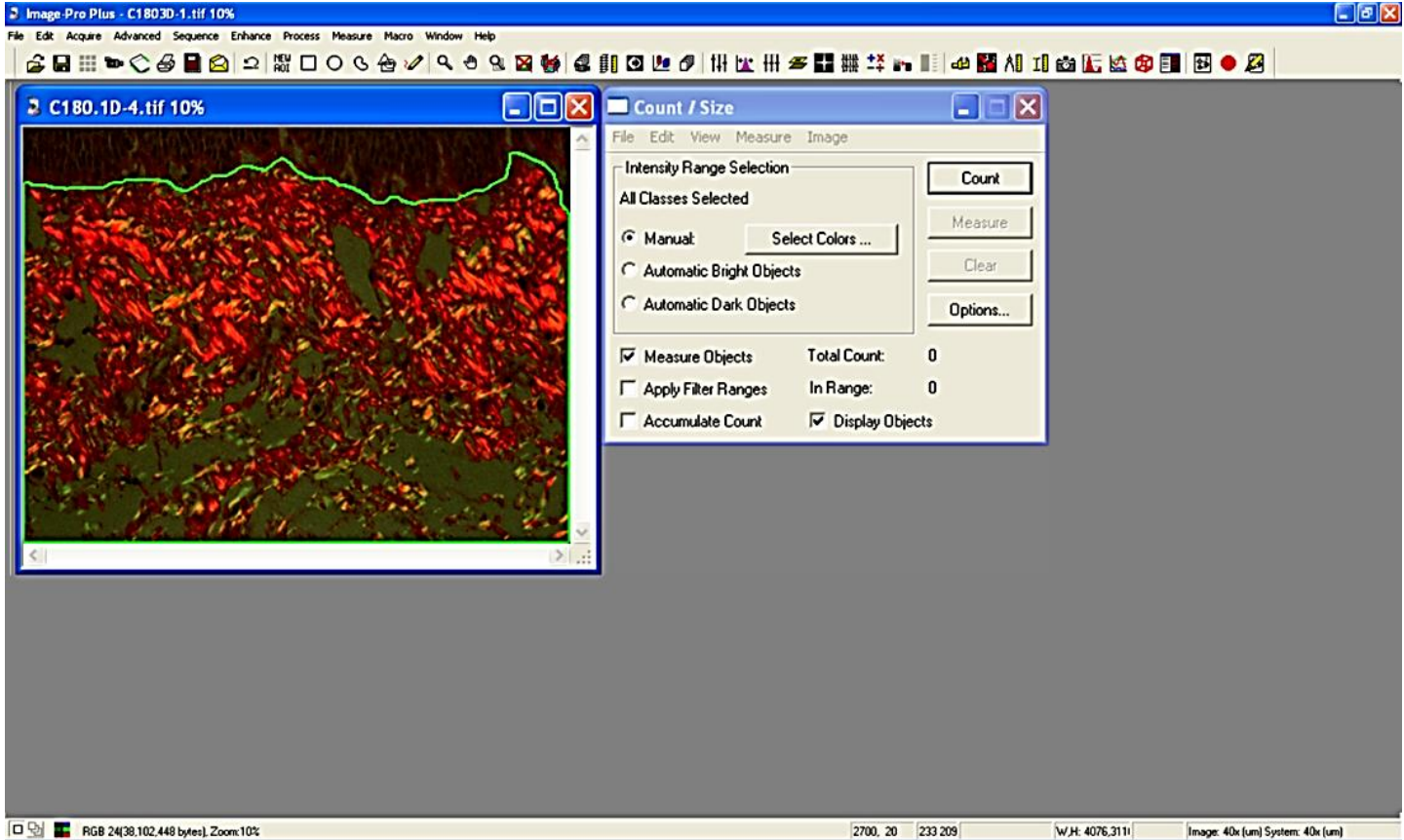

Figura 12: Interface do programa de análise digital de imagem que mostra a fotomicrografia com delimitação da área de interesse para quantificação de fibras de colágeno marcada em verde. Aumento de 400x

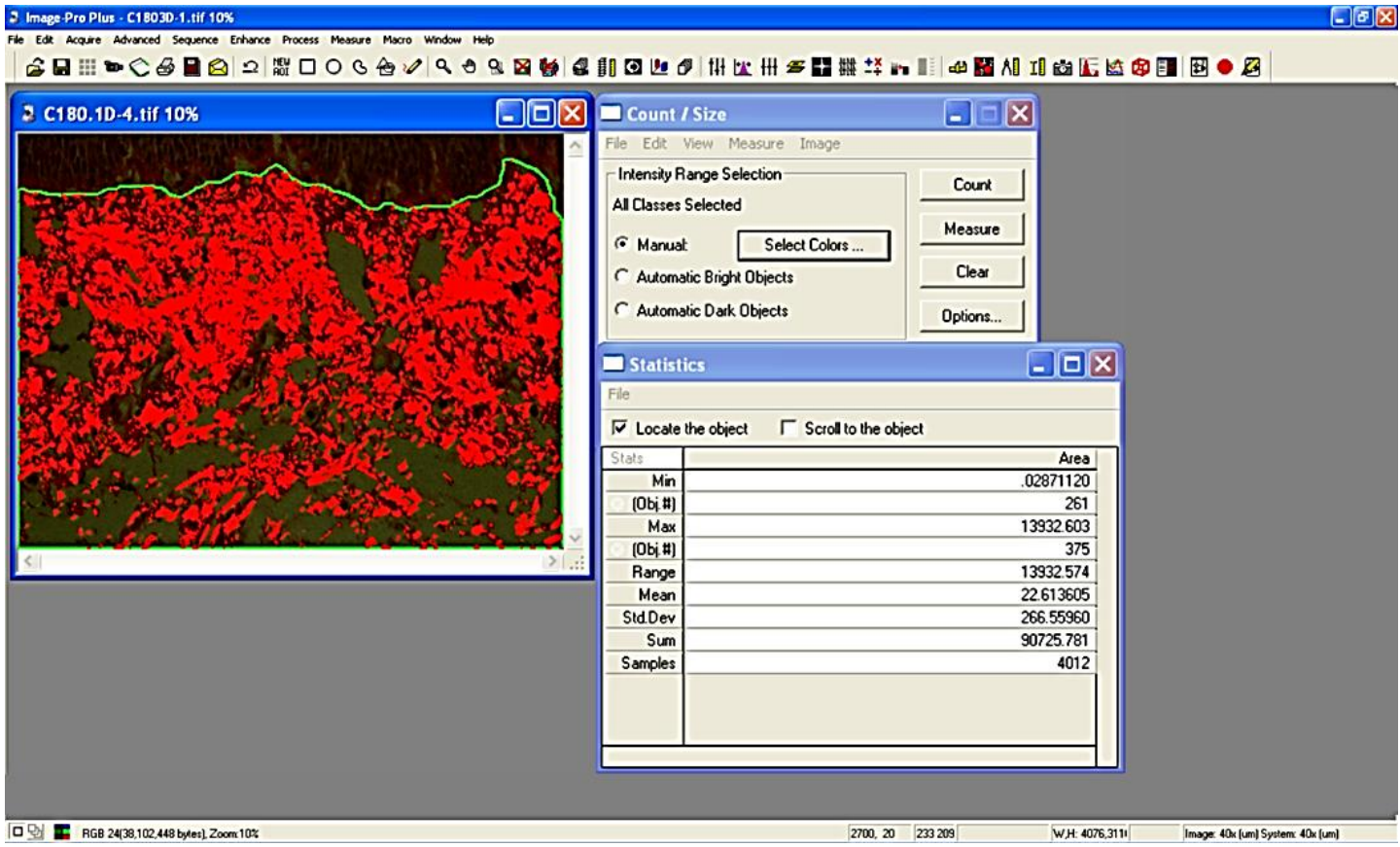

Figura 13: Interface do programa de análise digital de imagem que mostra a fotomicrografia com delimitação da área de interesse e reconhecimento das frequências de luz birrefringentes correspondentes às fibras colágenas, marcando-as em vermelho, expressa em $\mu \mathrm{m}^{2}$. Aumento de 400x 


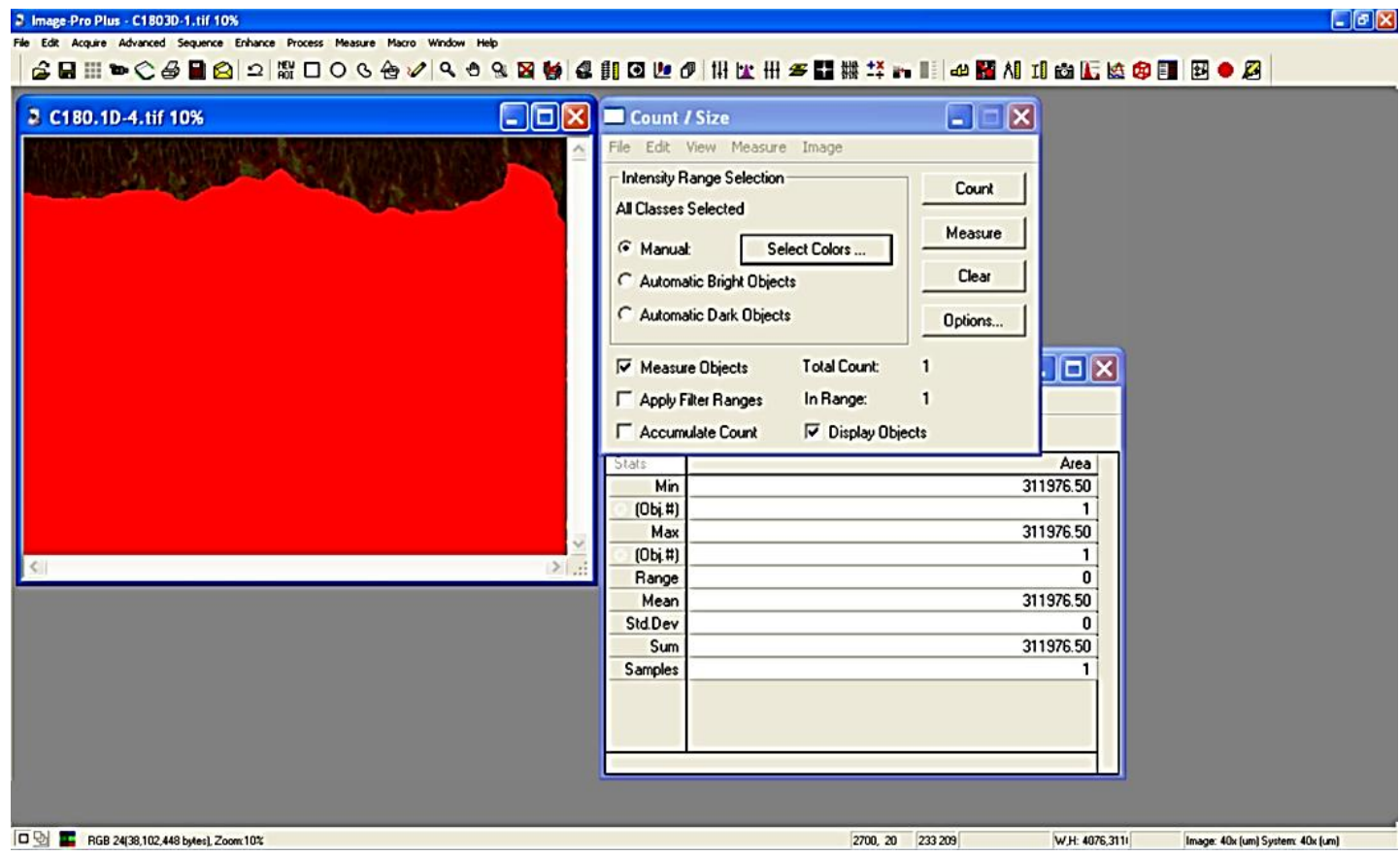

Figura 14: Interface do programa de análise digital de imagem que mostra a fotomicrografia com marcação da área total, expressa em $\mu^{2}$. Aumento de 400x

As mesmas imagens capturadas foram utilizadas para a avaliação e descrição subjetiva da disposição das fibras de colágeno.

Todas as análises quantitativas do infiltrado inflamatório, edema, hemorragia, fibras colágenas e descritivas do sistema de colágeno foram realizadas às cegas sem que o pesquisador tivesse conhecimento da prega vocal e do grupo que o corte histológico representava.

\subsection{Análise estatística}

A casuística era relativamente pequena e por causa da distribuição não paramétrica da maioria das variáveis, definidas pela análise visual dos histogramas e 
pelo teste de Shapiro-Wilk, optou-se aplicar testes não paramétricos. Utilizou-se o teste de Wilcoxon para as observações pareadas (comparações entre as pregas vocais) e o teste de Mann-Whitney para as observações não pareadas (comparações entre os Grupos I e II).

Foi usado o programa STATA 11 (Stata Corp, College Station, TX) para as análises e adotou-se o nível de significância de 0,05 . 
5 RESULTADOS 


\section{RESULTADOS}

\subsection{Evolução dos coelhos durante o período observacional}

Não houve nenhuma morbidade documentada e todos os animais sobreviveram até o dia programado para seu sacrifício.

\subsection{Variáveis de interesse}

\subsubsection{Processo inflamatório na lâmina própria}

A avaliação do processo inflamatório na lâmina própria do Grupo I (sacrifício no $7^{\circ}$ dia de pós-operatório) demonstrou aumento não significativo na quantidade de células inflamatórias (linfócitos, monócitos, macrófagos e plasmócitos) na prega vocal direita (Figuras 15A, B). A Tabela 1 mostra os dados da comparação do processo inflamatório entre as pregas vocais do grupo sacrificado no $7^{\circ}$ dia de pósoperatório. 

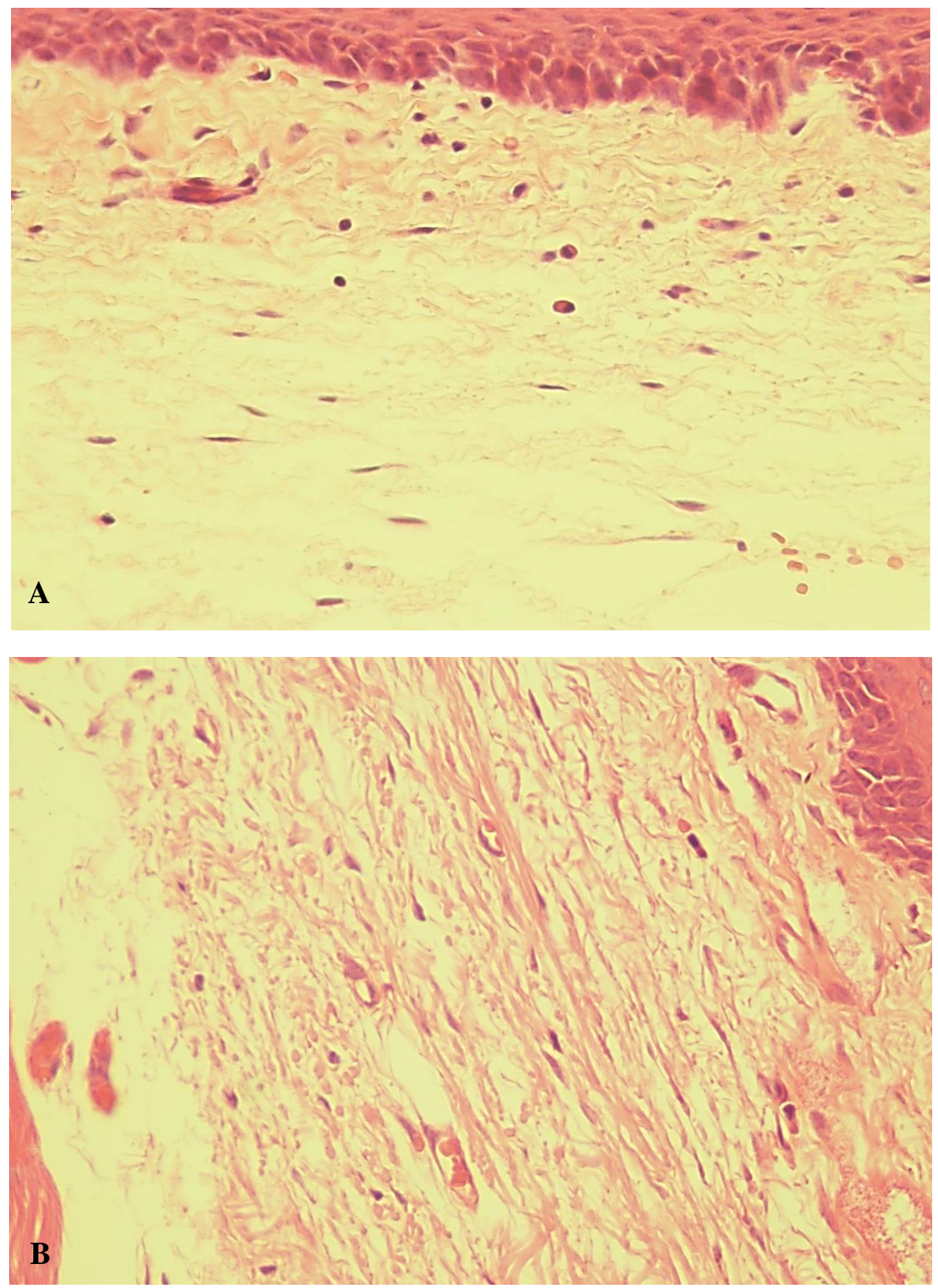

Figura 15: Corte histológico corado com hematoxilina-eosina de prega vocal esquerda (controle) (A) e direita (intervenção) (B) do Grupo I (sacrifício no $7^{\circ}$ dia de pós-operatório). Aumento de $400 x$ 
Tabela 1: Comparação das variáveis inflamatórias entre prega vocal direita e esquerda do Grupo I (sacrifício no $7^{\circ}$ dia de pós-operatório)

\begin{tabular}{|c|c|c|c|}
\hline & $\begin{array}{c}\text { PV D } \\
\text { mediana } \\
\left(\mathbf{P}_{\mathbf{2 5} \%} ; \mathbf{P}_{\mathbf{7 5} \%}\right)\end{array}$ & $\begin{array}{c}\text { PV E } \\
\text { mediana } \\
\left(\mathbf{P}_{25 \%} ; \mathbf{P}_{75 \%}\right)\end{array}$ & $\mathbf{p}^{\S}$ \\
\hline Linfócitos & $\begin{array}{c}1,5 \\
(1,344 ; 1,983)\end{array}$ & $\begin{array}{c}0,947 \\
(0,338 ; 1,655)\end{array}$ & 0,128 \\
\hline $\begin{array}{l}\text { Monócitos/ } \\
\text { Macrófagos }\end{array}$ & $\begin{array}{c}0,667 \\
(0,165 ; 0,759)\end{array}$ & $\begin{array}{c}0,237 \\
(0,0,828)\end{array}$ & 0,866 \\
\hline Neutrófilos & $\begin{array}{c}0 \\
(0 ; 0,267)\end{array}$ & $\begin{array}{c}0 \\
(0 ; 0)\end{array}$ & 0,212 \\
\hline Plasmócitos & $\begin{array}{c}0,384 \\
(0,165 ; 0,759)\end{array}$ & $\begin{array}{c}0,113 \\
(0,0,294)\end{array}$ & 0,176 \\
\hline $\begin{array}{l}\text { Total de células } \\
\text { inflamatórias }\end{array}$ & $\begin{array}{c}2,550 \\
(2,495 ; 3,056)\end{array}$ & $\begin{array}{c}1,657 \\
(0,666 ; 2,759)\end{array}$ & 0,237 \\
\hline Edema & $\begin{array}{c}4,890 \\
(1,152 ; 6,333)\end{array}$ & $\begin{array}{c}3,586 \\
(0,965 ; 9,468)\end{array}$ & 0,176 \\
\hline Hemorragia & $\begin{array}{c}0,885 \\
(0 ; 3,338)\end{array}$ & $\begin{array}{c}1,909 \\
(0 ; 4,497)\end{array}$ & 0,9324 \\
\hline
\end{tabular}

PV D: prega vocal direita (intervenção); PV E: prega vocal esquerda (controle); $\mathrm{P}_{25 \%}$ : percentil 25\%; $\mathrm{P}_{75 \%}$ : percentil $75 \%$; p: nível descritivo; ${ }^{\S}$ : teste de Wilcoxon

No Grupo II (sacrifício no $180^{\circ}$ dia de pós-operatório), as diferenças na quantidade de células inflamatórias, edema e hemorragia entre as pregas vocais, direita (intervenção) e esquerda (controle), foram estatisticamente não significantes (Figura 16 e Tabela 2). 


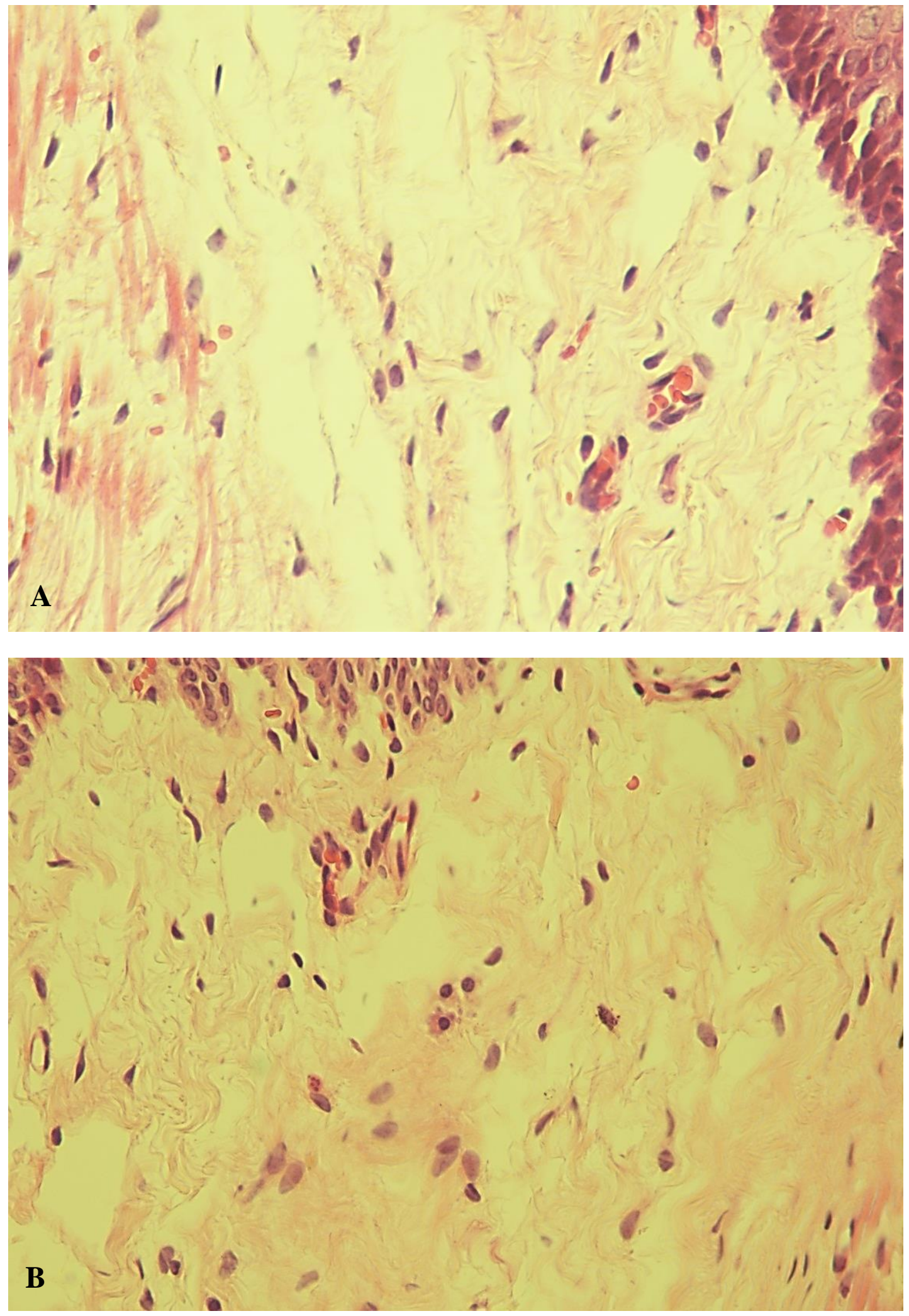

Figura 16: Corte histológico corado com hematoxilina-eosina de prega vocal, esquerda (controle) (A) e direita (intervenção) (B), do Grupo II (sacrifício no $180^{\circ}$ dia de pós-operatório). Aumento de 400x 
Tabela 2: Comparação das variáveis inflamatórias entre prega vocal direita e esquerda do Grupo II (sacrifício no $180^{\circ}$ dia de pós-operatório)

\begin{tabular}{lccc}
\hline & $\begin{array}{c}\text { PV D } \\
\text { mediana } \\
\left(\mathbf{P}_{\mathbf{2 5} \%}, \mathbf{P}_{\mathbf{7 5} \%)}\right)\end{array}$ & $\begin{array}{c}\text { PV E } \\
\text { mediana } \\
\left(\mathbf{P}_{\mathbf{2 5} \%}, \mathbf{P}_{\mathbf{7 5} \%}\right)\end{array}$ & $\mathbf{p}^{\S}$ \\
\hline Linfócitos & 1,625 & 1,258 & 0,866 \\
\hline Monócitos/ & $(0,570 ; 2,685)$ & $(0,911 ; 2,299)$ & \\
Macrófagos & 0,806 & 1,107 & 0,735 \\
\hline Neutrófilos & $(0,148 ; 1,675)$ & $(0 ; 1,631)$ & 0,722 \\
& 0 & 0 & 0,932 \\
\hline Plasmócitos & $(0 ; 0,114)$ & $(0 ; 0,142)$ & 0,735 \\
\hline Total de células & 0,295 & $(0 ; 0,911)$ & 2,214 \\
inflamatórias & $(0,228 ; 0,718)$ & $(2,164 ; 4,391)$ & 0,439 \\
\hline Edema & 2,228 & 0 & NA \\
\hline Hemorragia & $(2,052 ; 5,524)$ & $(0 ; 0,326)$ & 0 \\
\hline
\end{tabular}

PV D: prega vocal direita (intervenção); PV E: prega vocal esquerda (controle); $\mathrm{P}_{25 \%}$ : percentil 25\%; $\mathrm{P}_{75 \%}$ : percentil 75\%; p: valor descritivo; ${ }^{\S}$ : teste de Wilcoxon; NA: não analisado

Ao comparar as variáveis inflamatórias em relação ao tempo de sacrifício (Grupo I versus Grupo II), não houve diferença significativa na quantidade de células inflamatórias (linfócitos, monócitos, macrófagos, neutrófilos, plasmócitos) para nenhuma das pregas vocais. Ocorreu redução significativa do edema e hemorragia no Grupo II, tanto para a prega vocal esquerda (controle) $(\mathrm{p}=0,004$ e $\mathrm{p}=0,009$, respectivamente), quanto para a prega vocal direita (intervenção) $(p=0,008$ e $\mathrm{p}=0,025$, respectivamente). Os resultados acima descritos são mostrados nas Tabelas 3 e 4. 
Tabela 3: Comparação das variáveis inflamatórias da prega vocal esquerda (controle) entre Grupo I (sacrifício no $7^{\circ}$ dia de pós-operatório) e Grupo II (sacrifício no $180^{\circ}$ dia de pós-operatório)

\begin{tabular}{lccc}
\hline & $\begin{array}{c}\text { Grupo I } \\
\text { mediana } \\
\left(\mathbf{P}_{\mathbf{2 5} \%}, \mathbf{P}_{\mathbf{7 5}}\right)\end{array}$ & $\begin{array}{c}\text { Grupo II } \\
\text { mediana } \\
\left(\mathbf{P}_{\mathbf{2 5}}, \mathbf{P}_{\mathbf{7 5}}\right)\end{array}$ & $\mathbf{p}^{\S}$ \\
\hline Linfócitos & 0,947 & 1,258 & 0,110 \\
\hline Monócitos/ & $(0,338 ; 1,655)$ & $(0,911 ; 2,299)$ & 1,107 \\
Macrófagos & 0,237 & $(0 ; 1,631)$ & 0,333 \\
\hline Neutrófilos & $(0 ; 0,828)$ & 0 & 0,424 \\
\hline Plasmócitos & 0 & $(0 ; 0,142)$ & 0,272 \\
\hline Total de células & $(0 ; 0)$ & 0,354 & 0,142 \\
inflamatórias & 0,113 & $(0 ; 0,911)$ & 0,004 \\
\hline Edema & $(0 ; 0,294)$ & 2,214 & \\
& $(0,666 ; 2,759)$ & $(2,164 ; 4,391)$ & 0,009 \\
\hline Hemorragia & 3,586 & 0 & 0 \\
& $(0,965 ; 9,468)$ & $(0 ; 0,326)$ & 0 \\
\hline
\end{tabular}

$\mathrm{P}_{25 \%}$ : percentil $25 \% ; \mathrm{P}_{75 \%}$ : percentil 75\%; p: nível descritivo; ${ }^{\$}$ : teste de Mann-Whitney

Tabela 4: Comparação das variáveis inflamatórias da prega vocal direita (intervenção) entre Grupo I (sacrifício no $7^{\circ}$ dia de pós-operatório) e Grupo II (sacrifício no $180^{\circ}$ dia de pós-operatório)

\begin{tabular}{lccc}
\hline & $\begin{array}{c}\text { Grupo I } \\
\text { mediana } \\
\left(\mathbf{P}_{\mathbf{2 5} \%}, \mathbf{P}_{\mathbf{7 5}}\right)\end{array}$ & $\begin{array}{c}\text { Grupo II } \\
\text { mediana } \\
\left(\mathbf{P}_{\mathbf{2 5}}, \mathbf{P}_{\mathbf{7 5}}\right)\end{array}$ & $\mathbf{p}^{\S}$ \\
\hline Linfócitos & $\begin{array}{c}1,5 \\
(1,344 ; 1,983)\end{array}$ & $\begin{array}{c}1,625 \\
(0,570 ; 2,685)\end{array}$ & 0,949 \\
\hline $\begin{array}{l}\text { Monócitos/ } \\
\text { Macrófagos }\end{array}$ & $\begin{array}{c}0,667 \\
(0,165 ; 0,759)\end{array}$ & $\begin{array}{c}0,806 \\
(0,148 ; 1,675)\end{array}$ & 0,371 \\
\hline Neutrófilos & 0 & 0 & 0,524 \\
\hline Plasmócitos & $(0 ; 0,267)$ & $(0 ; 0,114)$ & 0,655 \\
\hline $\begin{array}{l}\text { Total de células } \\
\text { inflamatórias }\end{array}$ & $(0,165 ; 0,759)$ & $(0,228 ; 0,718)$ & 0,749 \\
\hline Edema & $\begin{array}{c}2,550 \\
(2,495 ; 3,056)\end{array}$ & $(2,052 ; 5,524)$ & 0,008 \\
\hline Hemorragia & $\begin{array}{c}4,890 \\
(1,152 ; 6,333)\end{array}$ & $(0 ; 0,783)$ & 0,025 \\
\hline
\end{tabular}

$\mathrm{P}_{25 \%}$ : percentil 25\%; $\mathrm{P}_{75 \%}$ : percentil 75\%; p: nível descritivo; ${ }^{\$}$ : teste de Mann-Whitney 
5.2.2 Distribuição das fibras de colágeno e densidade de colágeno na lâmina própria

Ao avaliar os cortes histológicos corados com Picrossírius do Grupo I (sacrifício no $7^{\circ}$ dia de pós-operatório) em microscópio de polarização, observou-se a presença de fibras finas de colágeno dispostas em forma de rede na lâmina própria da prega vocal direita (intervenção), caracterizadas por fibras finas vermelhoalaranjadas e amarelo-esverdeadas, ancoradas na membrana basal do epitélio (Figura 17).

No tecido da prega vocal esquerda (controle), os cortes mostraram um predomínio de áreas de lâmina própria com conglomerado de fibras grossas de colágeno dispostas de forma paralela ao epitélio superficial, com predominância de fibras vermelho-alaranjadas (Figura 18). 


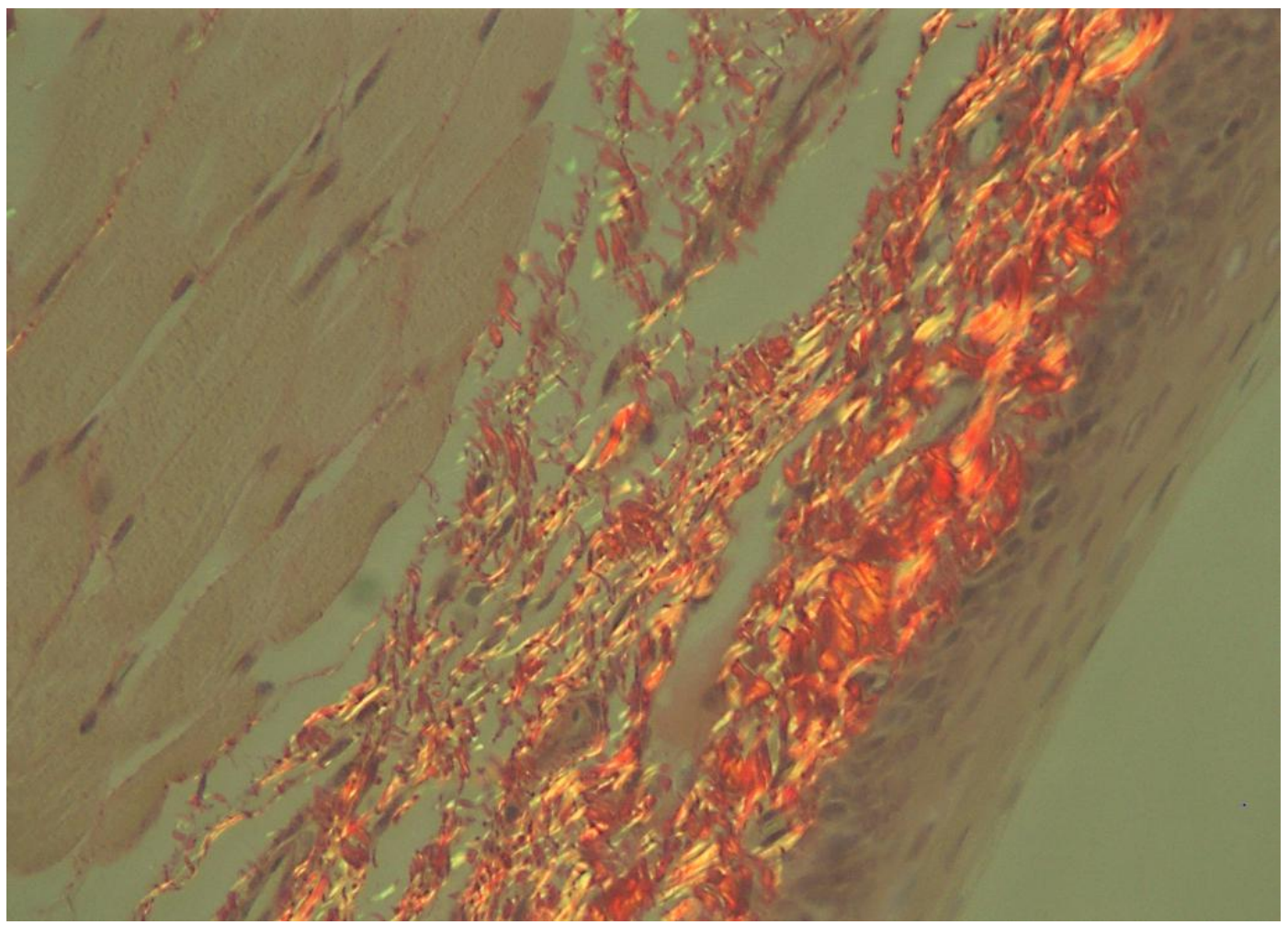

Figura 17: Corte histológico de prega vocal direita (intervenção) do Grupo I (sacrifício no $7^{\circ}$ dia de pós-operatório) corado com Picrossírius e visualizado sob luz polarizada. Aumento de 400x

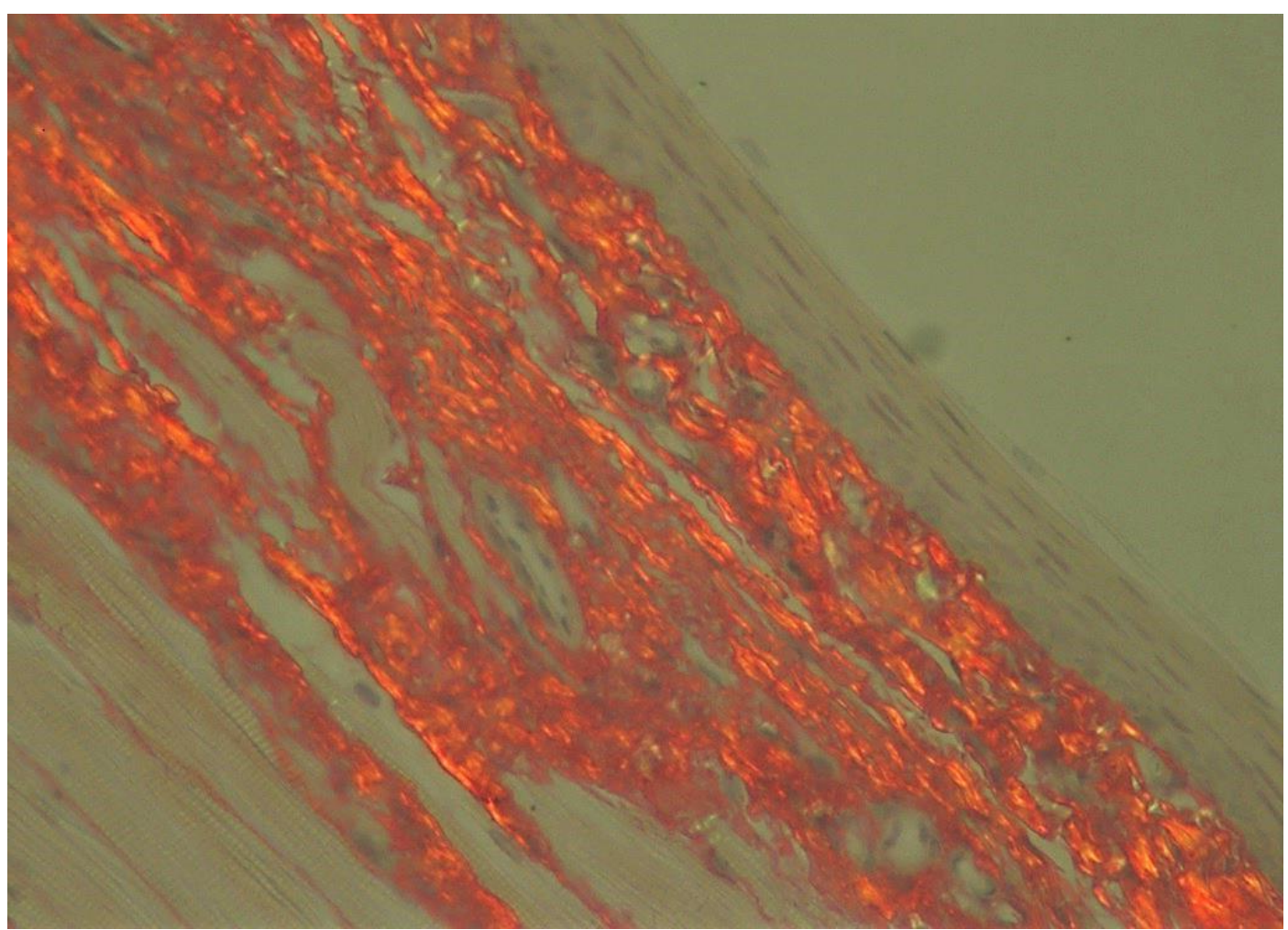

Figura 18: Corte histológico de prega vocal esquerda (controle) do Grupo I (sacrifício no $7^{\circ}$ dia de pós-operatório) corado com Picrossírius visualizado sob luz polarizada. Aumento de 400x 
Na lâmina própria da prega vocal esquerda (controle) do Grupo II (sacrifício no $180^{\circ}$ dia de pós-operatório), os cortes também mostraram fibras colágenas dispostas de forma paralela ao epitélio superficial e predomínio de fibras grossas vermelho-alaranjadas (Figura19). Contudo, isso ocorreu apenas nas camadas superficiais. Nas camadas mais profundas, estas fibras passaram a apresentar uma disposição reticular com presença de fibras vermelho-alaranjadas e amareloesverdeadas.

Na lâmina própria da prega vocal direita (intervenção) do Grupo II (sacrifício no $180^{\circ}$ dia de pós-operatório), observou-se a manutenção da disposição das fibras de colágeno em forma de rede fina vistas no Grupo I, mas agora com predomínio de fibras finas de coloração amarelo-esverdeadas (Figura 20). 


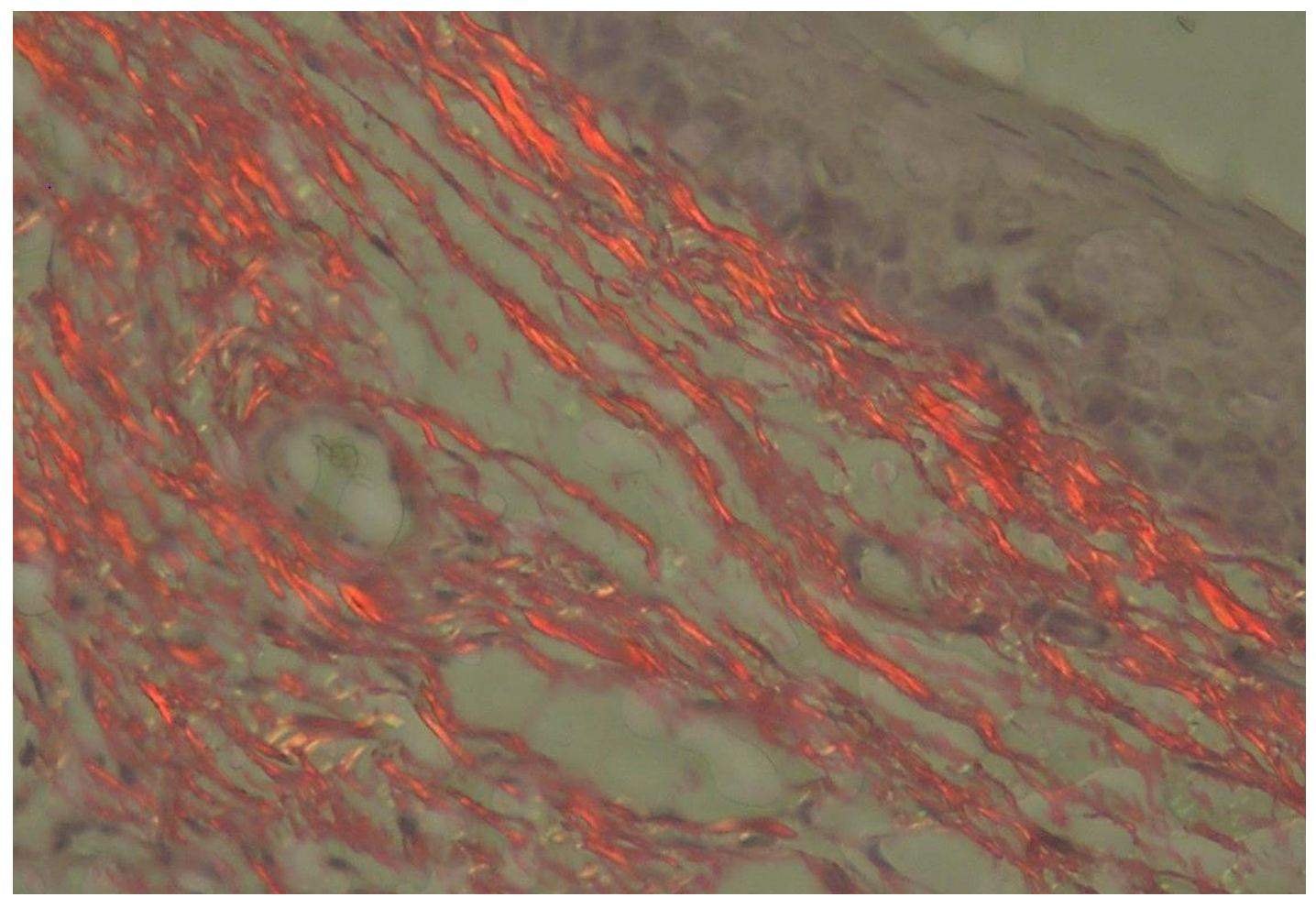

Figura 19: Corte histológico de prega vocal esquerda (controle) do Grupo II (sacrifício no $180^{\circ}$ dia de pós-operatório) corado com Picrossírius e visualizado sob luz polarizada. Aumento de 400x

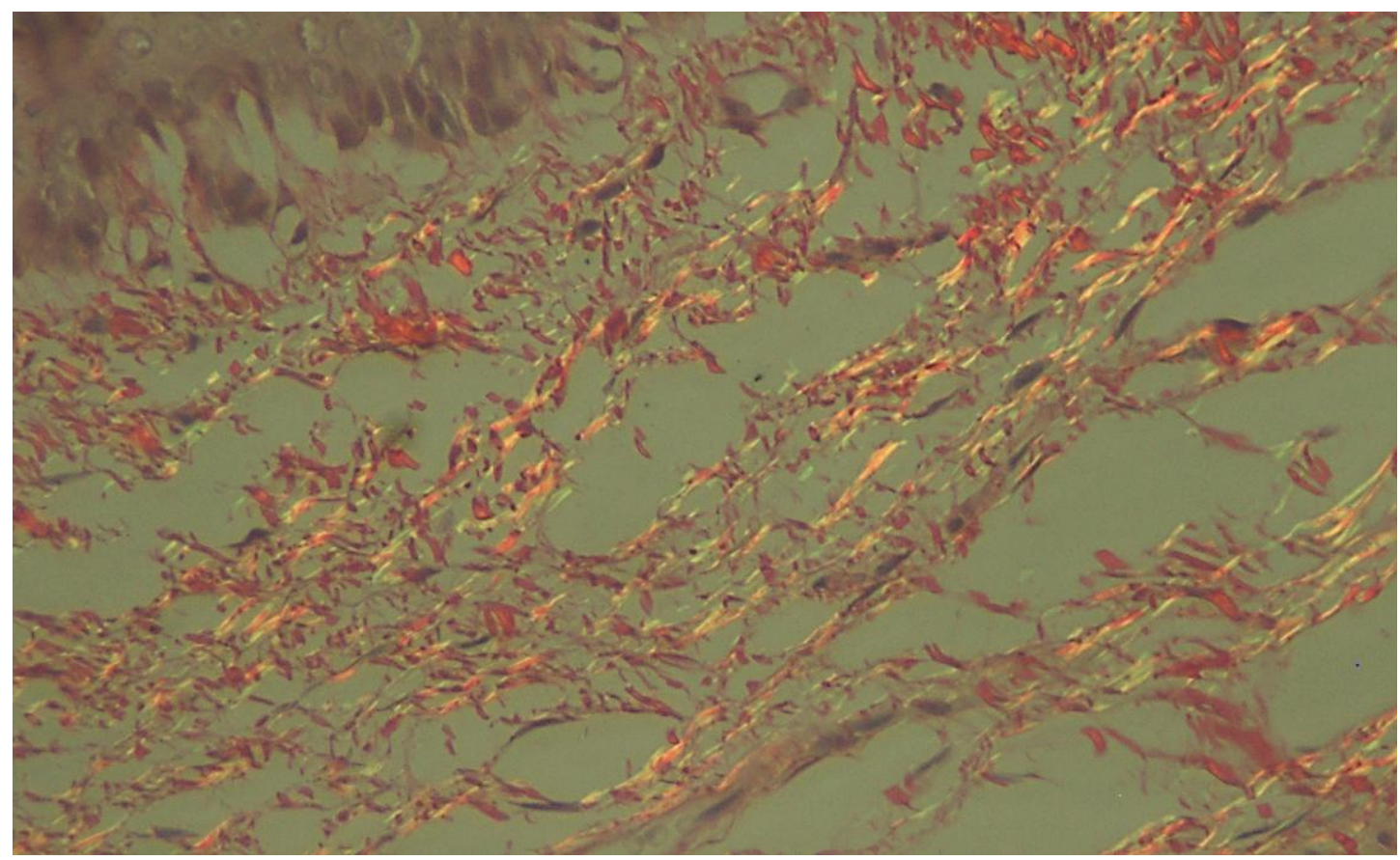

Figura 20: Corte histológico de prega vocal direita (intervenção) do Grupo II (sacrifício no $180^{\circ}$ dia de pós-operatório) corado com Picrossírius e visualizado sob luz polarizada. Aumento de 400x 
Quando analisadas as medianas de densidade de colágeno na lâmina própria entre as pregas vocais do Grupo I, foi possível observar uma tendência à redução de colágeno na prega vocal direita (intervenção), embora essa diferença não tenha sido estatisticamente significativa quando analisada por meio do teste de Wilcoxon $(\mathrm{p}=$ $0,091)$

Para o Grupo II, não houve diferença estatística quanto à densidade de colágeno entre as pregas vocais $(\mathrm{p}=0,499)$.

Quando comparadas em função do tempo de sacrifício (Grupo I versus Grupo II), não houve diferença significativa para nenhuma das pregas vocais analisadas $(\mathrm{p}=0,482$ e $\mathrm{p}=0,142$, para as pregas vocais esquerda e direita, respectivamente).

Os resultados da quantificação proporcional de fibras de colágeno e análise estatística estão dispostos na Tabela 5 e Anexo A.

Tabela 5: Média da densidade de colágeno das pregas vocais, esquerda e direita, nos Grupos I (sacrifício no $7^{\circ}$ dia de pós-operatório) e II (sacrifício no $180^{\circ}$ dia de pós-operatório)

\begin{tabular}{|c|c|c|c|c|c|}
\hline & \multicolumn{2}{|c|}{ PV D } & \multicolumn{2}{|c|}{ PV E } & \multirow{2}{*}{$\mathbf{p}^{\S}$} \\
\hline & $\mathbf{n}$ & $\begin{array}{c}\text { mediana } \\
\left(\mathbf{P}_{25 \%}, \mathbf{P}_{75 \%}\right)\end{array}$ & $\mathbf{n}$ & $\begin{array}{c}\text { mediana } \\
\left(\mathbf{P}_{25 \%}, \mathbf{P}_{75 \%}\right)\end{array}$ & \\
\hline Grupo I & 7 & $\begin{array}{c}9,883 \\
(7,178 ; 15,970)\end{array}$ & 7 & $\begin{array}{c}13,441 \\
(7,526 ; 22,338)\end{array}$ & 0,091 \\
\hline Grupo II & 7 & $\begin{array}{c}15,458 \\
(9,940 ; 28,825)\end{array}$ & 7 & $\begin{array}{c}19,066 \\
(8,090 ; 23,265)\end{array}$ & 0,499 \\
\hline $\mathbf{p}^{\S \S}$ & & 0,142 & & 0,482 & \\
\hline
\end{tabular}

PV D= prega vocal direita (intervenção); PV E= prega vocal esquerda (controle); $\mathrm{n}$ : quantidade de pregas vocais; $\mathrm{P}_{25 \%}$ : percentil 25\%; $\mathrm{P}_{75 \%}$ : percentil 75\%; p: nível descritivo; ${ }^{\S}$ : teste de Wilcoxon; $\$$ : teste de Mann-Whitney 


\section{DISCUSSÃO}

\subsection{Delineamento do estudo e metodologia}

A cicatriz de prega vocal é a principal causa de persistência ou recorrência de disfonia após microcirurgia de laringe (Woo et al., 1994) e representa um dos maiores desafios da laringologia na atualidade, uma vez que as abordagens existentes para sua correção apresentam resultados subótimos e inconsistentes (Hansen, Thibeault, 2006). Consequentemente, pesquisas relativas a esse tema aumentaram consideravelmente nos últimos anos, focando tanto na prevenção ou atenuação da formação de cicatriz após lesão tecidual, quanto na restauração da função vibratória nos casos de cicatriz crônica.

Os tratamentos profiláticos são fundamentados no conceito de que a fase aguda da cicatrização representa o período crítico no qual a intervenção terapêutica pode modificar a resposta inflamatória e, eventualmente, minimizar a formação de cicatriz (Bless, Welham, 2010). Isso ocorre porque a infiltração e a proliferação celular maciça no leito cicatricial são vistas no terceiro dia após a injúria tecidual, caracterizada por uma combinação de células inflamatórias e fibroblastos, que depositam elementos da nova matriz extracelular (Branski et al., 2005a; Bless, Welham, 2010). Dentre os elementos da matriz extracelular, o colágeno tem sido considerado o componente principal do tecido cicatricial (Thibeault et al., 2002). Em sua fase madura, a cicatriz apresenta-se com um aumento da densidade de colágeno e da espessura de seus feixes, levando a alterações biomecânicas que comprometem a 
fisiologia da fonação (Thibeault et al., 2002; Rousseau et al., 2003; Rousseau et al., 2004).

Este estudo foi desenhado com o intuito de avaliar se a injeção intraoperatória de corticosteroide traria benefícios em longo prazo no processo de cicatrização da prega vocal. Para isso, comparou-se as alterações inflamatórias, densidade e organização das fibras de colágeno entre pregas vocais que receberam ou não a injeção, avaliando-as na fase crônica de cicatrização e comparou-se esses achados com os da fase aguda de cicatrização, uma vez que Campagnolo et al. (2010) observaram menor deposição de colágeno nesse período.

Os corticosteroides estão entre os agentes de maior ação anti-inflamatória existentes. Dentre os corticosteroides disponíveis, escolheu-se o fosfato dissódico de dexametasona, que é facilmente solúvel em água, rapidamente absorvido e com efeito terapêutico de longa duração, visto que apresenta meia-vida plasmática que varia entre 36 e 72 horas (Schimmer, Parker, 2010). Foi injetado na prega vocal no intraoperatório, imediatamente após a lesão cirúrgica. Dessa forma, ocorreu a ação de um corticosteroide de potência alta desde o princípio da resposta inflamatória até o período crítico de início da síntese de matriz extracelular. Ao aplicar a substância intralesionalmente atinge-se uma concentração alta no local lesionado e minimiza-se a ocorrência de efeitos colaterais sistêmicos (Campagnolo et al., 2008; Tateya, 2009; Mortensen, 2010).

O coelho foi utilizado como modelo animal para este trabalho, escolha que é justificada pela similaridade dos aspectos histológicos de sua prega vocal com a do ser humano (Thibeault et al., 2002; Rousseau et al., 2004). Nela, é possível 
identificar uma diferenciação em camadas que, à semelhança dos humanos, é caracterizada pela presença de um epitélio escamoso que recobre o espaço subepitelial, a lâmina própria, que contém os componentes principais de matriz extracelular, como colágeno, elastina e ácido hialurônico, e, mais profundamente, o músculo tireoaritenóideo (Thibeault et al., 2002). Apesar de apresentar apenas duas camadas, a prega vocal de coelho apresenta distribuição e densidade de fibras de colágeno e elastina semelhantes à prega vocal humana (Kurita et al., 1983). Desse modo, a laringe de coelho tem sido amplamente utilizada em diversos estudos que envolvem histologia da prega vocal e resposta imunológica, em especial cicatrização de prega vocal, o que permite obter dados comparativos. Além disso, o coelho é um animal relativamente barato e de fácil manipulação e manutenção em um ambiente laboratorial (Rousseau et al., 2004).

A escolha do tempo de pós-operatório em que os animais foram sacrificados baseou-se em análise de estudos preliminares. A avaliação da cicatrização no $7^{\circ}$ dia de pós-operatório foi motivada pelos achados do estudo de Branski et al. (2005a) em prega vocal de coelho, no qual os autores observaram deposição de colágeno novo no $5^{\circ}$ dia e presença de colágeno mais maduro ao $7^{\circ}$ dia pós-injúria tecidual. Segundo o trabalho de Rousseau et al. (2004), a fase madura de cicatrização já está presente na prega vocal de coelho no $6^{\circ}$ mês de pós-operatório e este período é considerado adequado para avaliação de efeitos de tratamento sobre cicatriz crônica nesse modelo animal.

Para a realização da análise histomorfométrica da lâmina própria da prega vocal, foram utilizados dois métodos de coloração: hematoxilina-eosina e Picrossírius-polarização. A coloração com HE é usada com mais frequência em 
histologia e permite o estudo das alterações referentes ao infiltrado de células inflamatórias. Já o método Picrossírius-polarização é sensível e específico para colágeno e é superior à coloração de Van Gieson e os tricrômios, que por vezes falham em corar fibras colágenas muito finas, levando a subavaliação da quantidade de colágeno (Junqueira et al., 1979; Montes, Junqueira, 1991). Apesar de Junqueira et al. (1978) proporem a possibilidade de diferenciar os colágenos I, III e IV por meio das diferentes cores vistas à luz polarizada nesse método, trabalhos subsequentes mostraram que a polarização é também influenciada pela espessura das fibras de colágeno e pela densidade de seus feixes (Junqueira et al., 1982; Dayan et al., 1989). Frente a essa limitação do método, optou-se por quantificar a densidade total de colágeno na lâmina própria e não seus subtipos.

\subsection{Efeito da dexametasona sobre a lâmina própria}

\subsubsection{Processo inflamatório}

No presente estudo, observou-se uma tendência ao aumento das células inflamatórias (linfócitos, monócitos, macrófagos e plasmócitos) na prega vocal que recebeu injeção de dexametasona no grupo sacrificado no $7^{\circ}$ dia de pós-operatório. A avaliação temporal entre a fase aguda (7 dias) e crônica (180 dias) revela, como seria de se esperar, redução significativa do grau de edema e hemorragia tanto na prega vocal injetada com corticosteroide quanto na prega vocal controle. 
Os resultados vão de encontro dos achados de outros estudos existentes na literatura. Em estudo prévio conduzido na Disciplina de Otorrinolaringologia da FMUSP, com avaliação em fase mais precoce ( $3^{\circ}$ e $7^{\circ}$ dias após a lesão), também foi encontrada quantidade maior de células inflamatórias na prega vocal de coelho que recebeu injeção de dexametasona, embora essa diferença não tenha sido estatisticamente significante (Campagnolo et al., 2010).

Em experimento com avaliação em três tempos diferentes (2, 4 e 6 semanas após a lesão), Coleman et al. (1999) encontraram aumento significativo de infiltrado inflamatório ao redor do "microflap" cirúrgico na prega vocal de cão tratada com triancinolona, quando comparada à prega vocal que sofreu a mesma lesão e não recebeu o tratamento. Segundo os autores, o aumento do infiltrado inflamatório foi decorrente do atraso da resposta inflamatória provocado pelo corticosteroide. A partir do uso de um modelo matemático para avaliação tempo-dependente da resposta inflamatória, cujas variáveis compreendiam tempo do pico de resposta, máxima amplitude de resposta e duração da resposta inflamatória, os autores mostraram que os corticosteroides atrasam a resposta inflamatória local em 12 dias para o infiltrado inflamatório e 21 dias para a resposta neovascular nas pregas vocais tratadas com corticosteroide. Apesar do atraso no processo cicatricial, não foram observadas alterações na aparência, amplitude ou onda mucosa entre as pregas vocais nas estroboscopias pré e pós-operatórias (estas realizadas no dia da eutanásia).

Os resultados do estudo de Durmus et al. (2003) corroboram a hipótese de Coleman et al. de que os corticosteroides atrasam a resposta inflamatória. Os autores analisaram a ferida operatória em dorso de rato no $14^{\circ}$ dia pós-lesão e também encontraram maior infiltrado de células inflamatórias em ratos que receberam 
dexametasona intraperitonealmente, imediatamente antes do procedimento cirúrgico, em comparação ao grupo controle, que recebeu solução salina. Além disso, a ferida operatória do grupo controle apresentava-se em estágio mais avançado de cicatrização, com maior grau de reepitelização e colagenização e menor vascularização, indicando atraso da fase inflamatória e proliferativa nos ratos tratados com dexametasona.

Apesar de esses estudos sugerirem que o aumento do infiltrado inflamatório seja decorrente do atraso da resposta inflamatória provocado pelo corticosteroide, não se pode, no caso presente, descartar a hipótese de que o efeito anti-inflamatório da dexametasona não foi importante o suficiente para compensar o maior trauma provocado pela introdução da agulha e distensão tecidual pela sua infusão. Acreditase, no entanto, que esse trauma é mínimo. Em estudo realizado por Hall et al. (2012), a indução de fonotrauma agudo provocou elevação da expressão dos genes associados à inflamação COX-2 e IL-1ß, mas não houve diferença significativa na expressão desses genes entre o grupo que foi submetido ao fonotrauma apenas e o grupo submetido a fonotrauma associado à injeção intracordal de solução placebo, demonstrando que o trauma associado à injeção é insignificante.

Qualquer que seja o efeito do corticosteroide sobre o infiltrado inflamatório durante a fase aguda de cicatrização da prega vocal, este efeito parece não ser perpetuado em fases mais tardias. Ao analisar o grupo sacrificado no $180^{\circ}$ dia de pósoperatório, observou-se que a diferença de infiltrado inflamatório entre as pregas vocais é estatisticamente insignificante. Também não se constatou variação significativa quanto ao infiltrado inflamatório nas pregas vocais, quando os dois períodos foram comparados. 


\subsubsection{Fibras de colágeno}

Ao avaliar a densidade de colágeno na lâmina própria da prega vocal do grupo sacrificado no $7^{\circ}$ dia de pós-operatório, observou-se uma tendência à redução de colágeno na prega vocal que recebeu injeção de dexametasona $(\mathrm{p}=0,09)$.

Os achados do grupo sacrificado na fase aguda de cicatrização são próximos aos encontrados em estudo prévio efetuado na Disciplina de Otorrinolaringologia da FMUSP (Campagnolo et al., 2010). Nesse estudo, foi encontrada taxa de depósito de colágeno significativamente menor no grupo tratado com corticosteroide no $3^{\circ}$ e $7^{\circ}$ dias pós-lesão. Acredita-se que pequenas diferenças em relação à metodologia podem explicar a não igualdade dos resultados entre os estudos. No estudo de Campagnolo et al., foi provocada uma lesão diminuta de $2 \mathrm{~mm}$ na prega vocal, ao passo que no presente estudo, a lesão abrangeu toda sua extensão, provocando trauma cirúrgico e, consequentemente, reação inflamatória maiores. Como a dose de dexametasona aplicada intralesionalmente foi igual nos dois trabalhos, diferenças na relação reação inflamatória/ação anti-inflamatória do corticosteroide podem ter influenciado nossos resultados.

Ao analisar a evolução, foi observado que a tendência de redução na densidade de colágeno na prega vocal injetada não se mantém ao longo do tempo e não se observa diferença entre as pregas vocais 180 dias após a cirurgia. Não se pode afirmar, contudo, em que momento essa mudança ocorre. Como o intuito do estudo era avaliar os resultados na fase tardia de cicatrização e compará-los com os achados da fase aguda, não foi incluído um grupo que fosse sacrificado entre esses dois tempos. Existe, no entanto, o trabalho realizado por Alencar et al. (2007), que 
avaliaram os efeitos da injeção de dexametasona na prega vocal de suínos, imediatamente antes da realização de "microflap" no $30^{\circ}$ dia de pós-operatório. Nele, os autores também não encontraram diferenças significativas no depósito de colágeno total no grupo operado com dexametasona em relação ao grupo operado sem essa substância.

Esses achados permitem conjecturar que a densidade de colágeno na prega vocal tratada com corticosteroide sofra variação com o decorrer do processo cicatricial e que a tendência à redução na densidade de colágeno observada na fase aguda possa ser decorrente de uma ação do corticosteroide, que independe do grau de infiltrado inflamatório. De fato, estudos experimentais nos quais foi utilizado corticosteroide em derme e fibroblastos de humanos e ratos, mostraram haver redução na síntese de colágeno por meio da modulação dos níveis de RNAm funcional de colágeno, com redução da síntese do RNAm e inativação de enzimas necessárias à sua biossíntese (Cutroneo et al., 1981; Oikarinen et al., 1998; Oishi et al.,2002) .

Em geral, há certo entendimento entre os autores que a cicatriz e sua rigidez estão correlacionadas com o aumento de fibrose ou aumento na densidade de colágeno. Entretanto, a relação entre a rigidez, viscosidade tecidual e alterações nas proteínas fibrilares (colágeno e elastina) parece não ser tão direta assim. Resultados do estudo conduzido por Thibeault et al. (2002) mostraram que o aumento na rigidez e viscosidade da cicatriz não estavam associados ao aumento do colágeno em si, mas sim à perda de sua arquitetura normal, o que possivelmente altera a relação entre proteínas intersticiais e fibrilares. Os componentes fibrilares e intersticiais da lâmina própria apresentam funções biomecânicas importantes, que contribuem para a 
vibração adequada da onda mucosa durante a fonação. Segundo Rousseau et al. (2004), a deposição de feixes mais espessos de colágeno durante a cicatrização da prega vocal também contribui para a rigidez de sua lâmina própria, influenciando suas propriedades viscoelásticas.

Ao analisar a disposição e morfologia das fibras de colágeno neste estudo, pode-se afirmar, então, que a injeção de dexametasona, apesar de não ter promovido redução na taxa de depósito de colágeno ao $180^{\circ}$ dia após o procedimento, pode ter tido impacto positivo na cicatrização. Estudos de cicatrização de prega vocal mostram que a prega vocal normal de coelho apresenta fibras de colágeno esparsamente distribuídas, em contraste com feixes de colágeno espessos e em disposição laminar de uma prega vocal lesionada (Rousseau et al. 2004; Branski et al., 2005a). No presente estudo observou-se, também, que as fibras de colágeno das pregas vocais lesionadas e que não receberam tratamento (controle) eram mais grossas e dispunham-se paralelamente ao epitélio superficial, ao passo que as fibras das pregas vocais tratadas com dexametasona eram mais finas e estavam esparsamente dispostas de forma reticular, ou seja, melhor organizadas e com arquitetura de fibras mais próxima de uma prega vocal normal. Um estudo reológico, no entanto, é necessário para comprovar se a diferença na disposição e espessura das fibras de colágeno aqui encontrada, realmente tem impacto na viscoelasticidade da prega vocal.

Apesar das semelhanças histológicas entre a prega vocal de coelho e a humana, que justificam seu uso como modelo experimental em diversos estudos, o coelho é um animal desprovido de capacidade fonatória. Sabe-se que forças mecânicas podem alterar a expressão de genes da matriz extracelular, promover a 
síntese de pró-colágeno e estimular o "turnover" do colágeno (Bishop, 1998; Chiquet, 1999; Parsons et al., 1999). Destarte, não se sabe se a prega vocal humana, ao ser constantemente submetida a forças externas de fonação, tosse e deglutição, apresentaria diferenças na expressão de colágeno durante a cicatrização, quando comparada com a do coelho, o que limita, de certa forma, a transposição dos achados deste estudo, para a prática clínica. Para Thibeault et al. (2002), o padrão e a distribuição dos elementos da matriz extracelular entre os dois, ainda assim, seriam comparáveis.

\subsection{Perspectivas futuras}

Este estudo foi pioneiro em avaliar os efeitos da injeção de dexametasona na fase crônica de cicatrização de prega vocal de coelho, demonstrando não haver diferença no infiltrado inflamatório nem na densidade total de colágeno. A despeito disso, foi observada modificação na organização e espessura das fibras colágenas.

A metodologia do estudo, entretanto, não incluiu avaliação funcional das pregas vocais. Dessa forma, novos estudos que avaliem as propriedades viscoelásticas dessas pregas vocais, por meio de métodos reológicos ou pela videoestroboscopia adaptada ao modelo animal, permitiriam saber se essas alterações aqui encontradas têm impacto na vibração cordal. 
7 CONCLUSÃO 


\section{CONCLUSÃO}

Os resultados do presente estudo permitem concluir que a injeção de dexametasona na prega vocal de coelho, apesar de não ter tido impacto significativo na quantidade de células inflamatórias ou na densidade de colágeno em avaliação no $7^{\circ}$ e $180^{\circ}$ dia de pós-operatório, promoveu uma melhor organização e menor espessura das fibras de colágeno durante a fase aguda de cicatrização, que perduraram na fase tardia de cicatrização. 
ANEXO

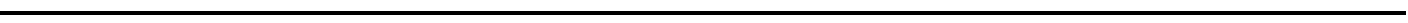


ANEXO A

MÉdIA DA ÁREA PROPORCIONAL DE COLÁGENO

\begin{tabular}{lcccc}
\hline & Coelho & $\begin{array}{c}\text { Sacrifício } \\
\text { (dias) }\end{array}$ & PV E (\%) & PV D (\%) \\
\hline Grupo I & 1 & 7 & 13,44057184 & 9,883118377 \\
& 2 & 7 & 17,62737243 & 15,97000121 \\
& 3 & 7 & 27,78991838 & 9,946388956 \\
& 4 & 7 & 22,33780236 & 25,11401 \\
& 5 & 7 & 5,054339434 & 3,071138496 \\
& 6 & 7 & 11,67004642 & 8,582299018 \\
\hline Grupo II & 7 & 7 & 7,525517957 & 7,17803893 \\
& 8 & 180 & 16,09804481 & 35,71993819 \\
& 9 & 180 & 19,71870641 & 15,45813827 \\
& 10 & 180 & 7,252315552 & 4,978115796 \\
& 11 & 180 & 19,06609922 & 25,23702693 \\
& 12 & 180 & 53,67763048 & 9,939662202 \\
& 13 & 180 & 8,089973749 & 13,94797986 \\
& 14 & 180 & 23,26458778 & 28,82502728
\end{tabular}

$\mathrm{PV} \mathrm{E}=$ prega vocal esquerda; $\mathrm{PV} \mathrm{D}=$ prega vocal direita; $\%=$ porcento

Área proporcional de colágeno $=$ (área de colágeno/área total lâmina própria) x100 
5 REFERÊNCIAS 


\section{REFERÊNCIAS}

Alencar BLF, Bapstistella E, Malafaia O, Czeczko NG, Scopel TF, Trotta F, Costa AFC, Watanabe SS, Silva TP. Experimental study of injetable corticoid in laryngeal microsurgery. Intl Arch Otorhinolaryngol. 2007;11(4):438-43.

Allen J. Cause of vocal fold scar. Curr Opin Otolaryngol Head Neck Surg. 2010;18:475-80.

Andrade Filho PA, Rosen CA. Vocal fold plaque following triamcinolone injection. Ear Nose Throat J. 2003;82:908-11.

Bailey AJ, Sims TJ, Le Lous, Bazin S. Collagen polymorphism in experimental granulation tissue. Biochem Biophys Res Commun. 1975;66(4):1160-5.

Balazs EA, Gibbs DA. The rheological properties and biological function of hyaluronic acid. In Balazs EA (ed): Chemistry and Molecular Biology of the Intercellular Matrix, vol. 3. New York, Academic Press, 1970, pp. 1241-1253.

Barbul A, Regan MC. Biology of wound healing. In: Fischer JA (ed). Surgical Basic Science. St. Louis, Mosby-Yearbook, 1993, pp. 67-89.

Benninger MS, Ahuja AS, Gardner G, Grywalski C. Assessing outcomes for dysphonic patients. J Voice. 1998;12(4):540-50.

Benninger MS, Alessi D, Archer S, Bastian R, Ford C, Koufman J, Sataloff RT, Spiegel JR, Woo P. Vocal fold scarring: current concepts and management. Otolaryngol Head Neck Surg. 1996;115(5):474-82.

Benninger MS, Murry T. The performer's voice. $1^{\text {st }}$ edition. Plural Publishing; 2006.

Bevilacqua MP, Pober JS, Wheeler ME, Cotran RS, Gimbrone MA Jr. Interleukin 1 acts on cultured human vascular endothelium to increase the adhesion of polymorphonuclear leukocytes, monocytes, and related leukocyte cell lines. J Clin Invest. 1985;76(5):2003-11.

Bishop JE. Regulation of cardiovascular collagen deposition by mechanical forces. Mol Med Today. 1998;4(2):69-75.

Bitar MA, Moukarbel RV, Zalzal GH. Management of congenital subglottic hemangioma: trends and success over the past 17 years. Otolaryngol Head Neck Surg. 2005;132(2):226-31. 
Bless DM, Welham NV. Characterization of vocal fold scar formation, prophylaxis, and treatment using animal models. Curr Opin Otolaryngol Head Neck Surg. 2010;18:481-6.

Bouchayer M, Cornut M. Microsurgery for benign lesions of the vocal folds. Ear Nose Throat J. 1988;67(6):446-9,452-4,456-64 passim.

Bower JS, Belen JE, Weg JG, Dantzker DR. Manifestations and treatment of laryngeal sarcoidosis. Am Rev Respir Dis. 1980;122:325-32.

Branski RC, Rosen CA, Verdolini K, Hebda PA. Acute vocal fold wound healing in a rabbit model. Ann Otol Rhinol Laryngol. 2005a;114:19-24.

Branski RC, Rosen CA, Verdolini K, Hebda PA. Biochemical markers associated with acute vocal fold wound healing: a rabbit model. $J$ Voice. 2005b;19(2):283-9.

Branski RC, Verdolini K, Rosen CA, Hebda PA. Markers of wound healing in vocal secretions from patients with laryngeal pathology. Ann Otol Laryngol. 2004;113:23-9.

Branski RC, Verdolini K, Sandulache V, Rosen CA, Hebda PA. Vocal fold wound healing: a review for clinicians. J Voice. 2006;20(3):432-42.

Brasil. Presidência da República. Casa Civil. Lei n ${ }^{\circ} 11794$ de 8 de outubro de 2008. Procedimentos para o uso científico de animais. Diário Oficial da União, Brasília (DF), 2008, 9 out; ed. 196, Seção 1:1-2.

Broughton G 2nd, Janis JE, Attinger CE. Wound healing: an overview. Plast Reconstr Surg. 2006;117(7 Suppl):1eS-32eS.

Campagnolo AM, Tsuji DH, Sennes LU, Imamura R. Injeção de corticosteroide em patologias vocais inflamatórias, revisão de literatura. Rev Bras Otorrinolaringol. 2008;74(6):926-32.

Campagnolo AM, Tsuji DH, Sennes LU, Imamura R, Saldiva PH. Histologic study of acute vocal fold wound healing after corticosteroid injection in a rabbit model. Ann Otol Rhinol Laryngol. 2010;119(2):133-9.

Catten M, Gray S, Hammond T, Zhou R, Hammond E. Analysis of cellular location and concentration in vocal fold lamina propria. Otolaryngol Head Neck Surg. 1998;18:663-7.

Chiquet M. Regulation of extracellular matrix gene expression by mechanical stress. Matrix Biol. 1999;18(5):417-26.

Cobb WB, Sudderth JF. Intralesional steroids in laryngeal stenosis. A preliminary report. Arch Otolaryngol. 1972;96(1):52-6. 
Cohen SM, Dupont WD, Courey MS. Quality-of-life impact of non-neoplastic voice disorders: a meta-analysis. Ann Otol Rhinol Laryngol. 2006;115(2):128-34.

Coleman JR Jr, Smith S, Reinisch L, Billante CR, Ossoff JP, Deriso W, Garrett CG. Histomorphometric and laryngeal videostroboscopic analysis of the effects of corticosteroids on microflap healing in the dog larynx. Ann Otol Rhinol Laryngol. 1999:108(2):119-27.

Coyle SM, Weinrich BD, Stemple JC. Shifts in relative prevalence of laryngeal pathology in a treatment-seeking population. J Voice. 2001;15(3):424-40.

Cutroneo KR, Rokowski R, Counts DF. Glucocorticoids and collagen synthesis: comparison of in vivo and cell cultures studies. Coll Relat Res. 1981;1(6):557-68.

Dayan D, Hiss Y, Hirshberg A, Bubis JJ, Wolman M. Are the polarization colors of Picrosirius red-stained collagen determined only by the diameter of the fibers? Histochem. 1989;93:27-9.

Doillon CJ, Dunn MG, Bender E, Silver FH. Collagen fiber formation in repair tissue: development of strength and toughness. Coll Relat Res. 1985;5(6):481-92.

Drake DB, Oishi SN. Wound healing considerations in chemotherapy and radiation therapy. Clin Plast Surg. 1995;22(1):31-7.

Durmus M, Karaaslan E, Ozturk E, Gulec M, Iraz M, Edali N, Ersoy MO. The effects of single-dose dexamethasone on wound healing in rats. Anesth Analg. 2003;97:1377-80.

Ehrlich HP, Krummel TM. Regulation of wound healing from a connective tissue perspective. Wound Repair Regen. 1996;4(2):203-10.

Folia M, Naiman N, Dubois R, Ayari S, Froehlich P. Management of postcricoid and upper esophageal hemangioma. Int J Pediatr Otorhinolaryngol. 2007;71(1):14751.

Garg HG, Warren CD, Siebert JW. Chemistry of scarring. In: Garg HG and Longaker MT, eds. Scarless Wound Healing. New York, NY: Marcel Dekker; 2000, pp. 1-22.

Garrett CG, Coleman JR, Reinisch L. Comparative histology and vibration of the vocal folds: implications for experimental studies in microlaryngeal surgery. Laryngoscope. 2010;110:814-24.

Garrett CG, Ossoff RH. Phonomicrosurgery II: surgical techniques. Otolaryngol Clin North Am. 2000;33(5):1063-70. 
Gnanapragasam, A. Intralesional steroids in conservative management of subglottic stenosis of the larynx. Int Surg. 1979;64(3):63-7.

Goldstein NA, Hebda PA, Klein EC, Dohar JE. Wound management of the airway mucosa: comparison with skin in a rabbit model. Int J Pediatr Otorhinolaryngol. $1998 ; 45: 223-35$.

Gourin CG, Terris DJ. Dynamics of wound healing. In: Bailey BJ, Jonhson JT, Shawn D, editors. Head and Neck Surgery - Otolaryngology. $4^{\text {th }}$ edition: Lippincott Williams \& Wilkin. 2006. Chapter 15.

Gray SD. Cellular physiology of the vocal folds. Otolaryngol Clin North Am. 2000;33(4):679-98.

Gray SD, Titze IR, Alipour F, Hammond TH. Biomechanical and histologic observations of vocal fold fibrous proteins. Ann Oto Rhinol Laryngol. 2000;109:77-85.

Grotendorst GR, Soma Y, Takehara K, Charette M. EGF and TGF-alpha are potent chemoattractants for endothelial cells and EGF-like peptides are present at sites of tissue regeneration. J Cell Physiol. 1989;139(3):617-23.

Gulati SP, Sachdeva OP, Sachdeva A, Singh U. Wegener's granulomatosis: a case with laryngeal involvement. Indian J Chest Dis Allied Sci. 1997;39(2):125-8.

Gundersen HJ, Bendtsen TF, Korbo L, Marcussen N, Moller A, Nielsen K, Nyengaard JR, Pakkenberg B, Sorensen FB, Vesterby A, West MJ. Some new, simple and efficient stereological methods and their use in pathological research and diagnosis. APMIS. 1988;96:379-94.

Hall JE, Suehiro A, Branski RC, Garrett CG, Rousseau B. Modulation of inflammatory and profibrotic signaling in a rabbit model of acute phonotrauma using triamcinolone. Otolaryngol Head Neck Surg. 2012;147(2):302-7.

Hansen JK, Thibeault S. Current understanding and review of the literature: vocal fold scarring. J Voice. 2006;20(1):110-20.

Hirano M. Morphological structure of the vocal cord as a vibrator and its variations. Folia Phoniatr. (Basel) 1974;26:89-94.

Hirano M. Phonosurgery: basic and clinical investigation. Otol. (Fukuoka) 1975;21(1):239-45.

Hirano, M. Structure of vocal fold in normal and disease states: anatomical and physical studies. ASHA Rep. 1981;11:11-30. 
Hirano M, Jackson L. Lecture: Phonosurgery: past, present, future. Amer Broncho Esophageal Assoc. 1995;25-30.

Hirano M, Kakita Y. Cover-body theory of vocal fold vibration. In: Danillof RG, editor. Speech science: recent advances. San Diego: College Hill Press; 1985, pp. $1-46$.

Hirano S, Minamiguchi S, Yamashita M, Ohno T, Kanemaru S, Kitamura M. Histologic characterization of human scarred vocal folds. $J$ Voice. 2009;23(4):399-407.

Hoeve LJ, Kuppers GL, Verwoerd CD. Management of infantile subglottic hemangioma: laser vaporization, submucous resection, intubation, or intralesional steroids? Int J Pediatr Otorhinolaryngol. 1997;42:179-86.

Hsu YB, Lan MC, Chang SY. Percutaneous corticosteroid injection for vocal fold polyp. Arch Otolaryngol Head Neck Surg 2009;135(8):776-80.

Ignotz RA. Transforming growth factor-B stimulates the expression of fibronectin and collagen and their incorporation into the extracellular matrix. J Biol Chem. 1986;261:4337-45.

Ishii K, Yamashita K, Akita M, Hirose H. Age-related development of the arrangement of connective tissue fibers in the lamina propria of the human vocal fold. Ann Otol Rhinol Laryngol. 2000;109:1055-64.

Isshiki N, Tsuji DH, Sennes LU. In Tireoplastias. $1^{\text {a }}$ edição. São Paulo: Fundação Otorrinolaringologia, 1999. Cap 1, p.19-20.

Jin HJ, Lee SH, Lee SU, Lee HS, Jin SM, Kim DH, Chae SW, Sohn JH. Morphological and histological changes of rabbit vocal fold after steroid injection. Otolaryngol Head Neck Surg. 2013;149(2):277-83.

Junqueira LC, Bignolas G, Brentani RR. Picrosirius staining plus polarization microscopy: a specific method for collagen detection in tissue sections. Histochem J. 1979;11(4):447-55.

Junqueira LC, Cossermelli W, Brentani R. Differential staining of collagens type I, II and III by Sirius Red and polarization microscopy. Arch Histol Jpn. 1978;41(3):267-74.

Junqueira LC, Montes GS, Sanchez EM. The influence of tissue section thickness on the study of collagen by the picrosirius-polarization method. Histochem. 1982;74(1):153-6. 
Kahane, JC. Connective tissue changes in the larynx and their effects on voice. $J$ Voice. 1987;1:27-30.

Kairys SW, Olmstead EM, O'Connor GT. Steroid treatment of laryngotracheitis: a meta-analysis of the evidence from randomized trials. Pediatrics. 1989;83:683-93.

Krespi YP, Mitrani M, Husain S, Meltzer CJ. Treatment of laryngeal sarcoidosis with intralesional steroid injection. Ann Otol Rhinol Laryngol. 1987;96:713-5.

Kurita S, Nagata K, Hirano M. A comparative study of the layer structure of the vocal fold. In: Bless DM, Abbs JH, eds. Vocal Fold Physiology: Contemporary Research and Clinical Issues. San Diego, California: College-Hill Press, Inc. 1983;3-21.

Kurkinen M, Vaheri A, Roberts PJ, Stenman S. Sequential appearance of fibronectin and collagen in experimental granulation tissue. Lab Invest. 1980;43(1):47-51.

Labat-Robert J, Bihari-Varga M, Robert L. Extracellular matrix. FEBS Lett. 1990;268:386-93.

Lander, AD. Proteoglycans. In: Kreis T, Vale R (eds): Guidebook to the Extracellular Matrix and Adhesion Proteins. New York, Oxford University Press, 1993, pp. 12-16.

Lawrence WT, Diegelmann RF. Growth factors in wound healing. Clin Dermatol. 1994;12(1):157-69.

Lee SH, Yeo JO, Choi JI, Jin HJ, Kim JP, Woo SH, Jin SM. Local steroid injection via the cricothyroid membrane in patients with a vocal nodule. Arch Otolaryngol Head Neck Surg. 2011:137(10);1011-16.

Madruga de Melo EC, Lemos M, Ximenes Filho JA, Sennes LU, Saldiva PHN, Tsuji DH. Distribution of collagen in the lamina propria of the human vocal fold. Laryngoscope. 2003;113:2187-91.

McDonald TJ, Neel HB $3^{\text {rd }}$, DeRemee RA. Wegener's granulomatosis of the subglotis and the upper portion of the trachea. Ann Otol Rhinol Laryngol. 1982;91(6Pt 1);588-92.

McKay LI, Cidlowski JA. Corticosteroids. In: Bast RC Jr, Kufe DW, Pollock RE, et al., editors. Holland-Frei Cancer Medicine. 5th edition. Hamilton (ON): BC Decker; 2000. Chapter 54. Available from: http://www.ncbi.nlm.nih.gov/ books/NBK20779/ 
Mirza N, Ruiz C, Baum ED, Staab JP. The prevalence of major psychiatric pathologies in patients with voice disorders. Ear Nose Throat J 2003;82(10):80814.

Montes GS, Junqueira LC. The use of the picrosirius-polarization method for the study of the biopathology of collagen. Mem Inst Oswaldo Cruz. 1991;86:1-11.

Mortensen M. Laryngeal steroid injection for vocal fold scar. Curr Opin Otolaryngol Head Neck Surg. 2010;18:487-91.

Mortensen M, Woo P. Office steroid injection of the larynx. Laryngoscope. 2006;116:1735-9.

Noordzij JP, Ossoff RH. Anatomy and physiology of the larynx. Otolaryngol Clin N Am. 2006;39:1-10.

Nussey S, Whitehead S. Endocrinology: An Integrated Approach. Oxford: BIOS Scientific Publishers; 2001. Chapter 4, The adrenal gland. Available from: http://www.ncbi.nlm.nih.gov/books/NBK26/

O TM, Alexander RE, Lando T, Grant NN, Perkins JA, Blitzer A, Waner M. Segmental hemangiomas of the upper airway. Laryngoscope. 2009;119(11):22427.

Oikarinen A, Haapasaari KM, Sutinen M et al. Molecular basis of glucocorticoidinduced skin atrophy: topical glucocorticoid apparently decreases both synthesis and corresponding mRNA level in human skin in vivo. $\mathrm{Br} J$ Dermatol. 1998;139:1106-10.

Oishi Y, Fu ZW, Ohnuki Y, Kato H, Noguchi T. Molecular basis of the alteration in skin collagen metabolism in response to in vivo dexamethasone treatment: effects on the synthesis of collagen type I and III, collagenase, and tissue inhibitors of metalloproteinases. Br J Dermatol. 2002;147(5):859-68.

Ossoff RH, Wolff AP, Ballenger JJ. Acute epiglottitis in adults: experience with fifteen cases. Laryngoscope. 1980; 90:1155-61.

Parrillo JE, Fauci AS. Mechanisms of glucocorticoid action on immune processes. Annu Rev Pharmacol Toxicol. 1979;19:179-201.

Parsons M, Kessler E, Laurent GJ, Brown RA, Bishop JE. Mechanical load enhances procollagen processing in dermal fibroblasts by regulating levels of procollagen C-proteinase. Exp Cell Res. 1999;252(2):319-31.

Pawlak AS, Hammond T, Hammond E, Gray SD. Immunocytochemical study of proteoglycans in vocal folds. Ann Otol Rhinol Laryngol. 1996;105(1):6-11. 
Perkins JA, Duke W, Chen E, Manning S. Emerging concepts in airway infantile hemangioma assessment and management. Otolaryngol Head Neck Surg. 2009;141(2):207-212.

Pierce GF, Mustoe TA, Altrock BW, Deuel TF, Thomason A. Role of plateletderived growth factor in wound healing. J Cell Biochem. 1991;45(4):319-26.

Pohlman TH, Stanness KA, Beatty PG, Ochs HD, Harlan JM. An endothelial cell surface factor(s) induced in vitro by lipopolysaccharide, interleukin 1 and tumor necrosis factor-alpha increases neutrophil adherence by a CDw18-dependent mechanism. J Immunol. 1986;136(12):4548-53.

Ramig LO, Verdolini K. Treatment efficacy: voice disorders. J Speech Lang Hear Res 1998;41(1):S101-16.

Rang HP, Dale MM, Ritter JM. A hipófise e o cortex supra-renal. In: Farmacologia. $4^{a}$ edição. Rio de Janeiro: Guanabara Koogan, 2001. Cap 24, p.337-54.

Rosekrans JA. Viral croup: current diagnosis and treatment. Mayo Clin Proc. 1998;73:1102-6.

Rosen CA. Vocal fold scar: evaluation and treatment. Otolaryngol Clin North Am. 2000;33(5):1081-6.

Rosen CA, Lee AS, Osborne J, Zullo T, Murry T. Development and validation of the voice handicap index-10. Laryngoscope. 2004;114(9):1549-56.

Rosen G, Vered IY. Triamcinolone acettonide injection for laryngeal stenosis. $J$ Laryngol Otol. 1975;89(10):1043-6.

Rousseau B, Hirano S, Chan RW, Welham NV, Thibeault S, Ford CN, Bless DM. Characterization of chronic vocal fold scarring in a rabbit model. J Voice. 2004; 18(1):116-24.

Rousseau B, Hirano S, Scheidt TD, Welham NV, Thibeault SL, Chan RW, Bless DM. Characterization of vocal fold scarring in a canine model. Laryngoscope. 2003;113:620-7.

Roy N, Merrill RM, Gray SD, Smith EM. Voice disorders in the general population: prevalence, risk factors, and occupational impact. Laryngoscope 2005;115(11):1988-95.

Roy N, Merrill RM, Thibeault S, Parsa RA, Gray SD, Smith EM. Prevalence of voice disorders in teachers and the general population. J Speech Lang Hear Res. 2004;47(2):281-93. 
Russell K, Wiebe N, Saenz A, Ausejo SM, Johnson D, Hartling L, Klassen TP. Glucocorticoids for croup. Cochrane Database Syst Rev. 2004;CD001955.

Saavedra-Delgado AM, Mathews KP, Pan PM, Kay DR, Muilenberg ML. Doseresponse studies of the suppression of whole blood histamine and basophil counts by prednisone. J Allergy Clin Immunol. 1980;66:464-71.

Saetti R, Silvestrini M, Cutrone C, Narme S. Treatment of congenital subglotic hemangioma: our experience compared with reports in the literature. Arch Otolaryngol Head Neck Surg. 2008;134(8):848-51.

Sapolsky RM, Romero LM, Munck AU. How do glucocorticoids influence stress response? Integrating permissive, suppressive, stimulatory, and preparative actions. Endocr Rev. 2000;21(1):55-89.

Sataloff RT, Hawkshaw MJ, Divi V, Heman-Acckah H. Voice surgery. Otolaryngol Clin North Am. 2007;40:151-83.

Schilling, J. Wound healing. Surg Clin North Am. 1976;56(4):859-74.

Schimmer BP, Parker KL. Hormônio adrenocorticotrópico; esteróides adrenocorticais e seus análogos sintéticos; inibidores da síntese e das ações dos hormônios adrenocorticais. In: Brunton LL, Lazo JS, Parker KL, editors. Goodman \& Gilman: as bases fisiológicas da terapêutica. Porto Alegre: Artmed; 2010. Cap. 59, p. 1433-57.

Siegel GJ, Agranoff BW, Albers RW, Fisher SK, Uhler MD, editors. Basic Neurochemistry: Molecular, Cellular and Medical Aspects. 6th edition. Philadelphia: Lippincott-Raven; 1999. Glucocorticoid and Mineralocorticoid Receptors as Transcription Factors. Available from: http://www.ncbi.nlm.nih.gov/ books/NBK28050/

Tateya, I. Laryngeal steroid injection. Curr Opin Otolaryngol Head Neck Surg. 2009;17(6):424-6.

Tateya I, Omori K, Kojima H, Hirano S, Kaneko K, Ito J. Steroid injection for Reinke's edema using fiberoptic laryngeal surgery. Acta Otolaryngol. 2003;123(3):417-20.

Tateya I, Omori K, Kojima H, Hirano S, Kaneko K, Ito J. Steroid injection to vocal nodules using fiberoptic laryngeal surgery under topical anesthesia. Eur Arch Otorhinolaryngol. 2004;261:489-92.

Thibeault SL, Bless DM, Gray SD. Interstitial protein alterations in the rabbit vocal fold with scar. J Voice. 2003;17:376-82. 
Thibeault SL, Gray SD, Bless DM, Chan RW, Ford CN. Histologic and rheologic characterization of vocal fold scarring. $J$ Voice. 2002;16:96-104.

Verdolini K, Rosen CA, Branski RC, Hebda PA. Shifts in biochemical markers associated with wound healing in laryngeal secretions following phonotrauma: a preliminary study. Ann Otol Rhinol Laryngol. 2003;112:1021-5.

Wang CT, Lai MS, Lo WC, Liao LJ, Cheng PW. Intralesional steroid injection: an alternative treatment option for vocal process granuloma in ten patients. Clin Otolaryngol. 2013:38(1):77-81.

Witte MB, Barboul A. General principles of wound healing. Surg Clin North Am. 1997;77:509-28.

Witte MB, Barboul A. Role of nitric oxide in wound repair. Am J Surg. 2002;183(4): 406-12.

Woo JH, Kim DY, Kim JW, Oh EA, Lee SW. Efficacy of percutaneous vocal fold injections for benign laryngeal lesions: prospective multicenter study. Acta Otolaryngol. 2011;131(12):1326-32.

Woo P, Casper J, Colton R, Brewer D. Diagnosis and treatment of persistent dysphonia after laryngeal surgery: a retrospective analysis of 62 patients. Laryngoscope. 1994;104(9):1084-91.

Woodson G. Developing a porcine model for study of vocal fold scar. J Voice. 2012;26(6):706-10.

Yanagihara N, Azuma F, Koike Y, Honjo I, Imanishi Y. Intracordal injection of dexamethasone. Pract Otorhinolaryngol. 1964;57:496-500.

Zhou H, Mahalakshmi Sivasankar, Krauss DH, Sandulache VC, Amin M, Branski RC. Glucocorticoids regulate extracellular matrix metabolism in human vocal fold fibroblasts. Laryngoscope. 2011;121:1915-9. 
APÊNDICE 


\section{APÊNDICE}

\section{CARTA DE APROVAÇÃO DA COMISSÃO DE ÉTICA}

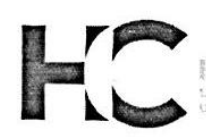

\section{APROVAÇĀO}

A Comissão de Ética para Análise de Projetos de Pesquisa CAPPesq da Diretoria Clínica do Hospital das Clínicas e da Faculdade de Medicina da Universidade de São Paulo, em sessão de 24/02/2010, APROVOU O Protocolo de Pesquisa n० 1308/09, intitulado: "AVALIAÇĀO HISTOPATOLÓGICA dOS EFEITOS TARDIOS DA INJEÇÃO DE CORTICOESTERÓIDES EM PREGA VOCAL DE COELHO", apresentado pelo Departamento de OFTALMOLOGIA E OTORRINOLARINGOLOGIA.

Cabe ao pesquisador elaborar e apresentar a CAPPesq, os relatórios parciais e final sobre a pesquisa (Resolução do Conselho Nacional de Saúde n 196, de 10/10/1996, inciso (X.2, letra "c").

Pesquisador (a) Responsável: PROF. DR. DOMINGOS HIROSHI TSUJI Pesquisador (a) Executante: MARYSTELLA TOMOE TAKAHASHI

CAPPesq, 25 de fevereiro de 2010

$$
\text { Es.s.s. }
$$

PROF. DR. EDUARDO MASSAD Presidente Comissão de Ética para Análise de Projetos de Pesquisa Comissão de Ética para Análise de Projetos de Pesquisa do HCFMUSP da Diretoria Clinica do Hospital das
Clinicas da Faculdade de Medicina da Universidade de São Paulo Rua Ovidio Pires de Campos, $225,5^{\circ}$ andar - CEP 05403010 - Såo Paulo - SP Fone: 01130696442 Fax: 01130696492 e-mail: cappesq@hcnet.usp.br / $\frac{\text { secretariacappesq2@hcnet.usp.br }}{\text { matc }}$ 